\title{
Vertical Neighborhood
}

\author{
Wenxi He

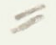 \\ School of Architecture \\ Carleton University \\ Ottawa, Ontario
}

A thesis submitted to the Faculty of Graduate Studies and Research in partial fulfillment of the requirements for the degree of Master of Architecture

(C)2005, Wenxi He 
Library and

Archives Canada

Published Heritage

Branch

395 Wellington Street

Ottawa ON K1A ON4

Canada
Bibliothèque et

Archives Canada

Direction du

Patrimoine de l'édition

395 , rue Wellington

Ottawa ON K1A ON4

Canada
NOTICE:

The author has granted a nonexclusive license allowing Library and Archives Canada to reproduce, publish, archive, preserve, conserve, communicate to the public by telecommunication or on the Internet, loan, distribute and sell theses worldwide, for commercial or noncommercial purposes, in microform, paper, electronic and/or any other formats.

The author retains copyright ownership and moral rights in this thesis. Neither the thesis nor substantial extracts from it may be printed or otherwise reproduced without the author's permission.
AVIS:

L'auteur a accordé une licence non exclusive permettant à la Bibliothèque et Archives Canada de reproduire, publier, archiver, sauvegarder, conserver, transmettre au public par télécommunication ou par l'Internet, prêter, distribuer et vendre des thèses partout dans le monde, à des fins commerciales ou autres, sur support microforme, papier, électronique et/ou autres formats.

L'auteur conserve la propriété du droit d'auteur et des droits moraux qui protège cette thèse. $\mathrm{Ni}$ la thèse ni des extraits substantiels de celle-ci ne doivent être imprimés ou autrement reproduits sans son autorisation.
In compliance with the Canadian

Privacy Act some supporting forms may have been removed from this thesis.

While these forms may be included in the document page count, their removal does not represent any loss of content from the thesis.
Conformément à la loi canadienne sur la protection de la vie privée, quelques formulaires secondaires ont été enlevés de cette thèse.

Bien que ces formulaires aient inclus dans la pagination, il n'y aura aucun contenu manquant.

\section{Canadä}




\section{ABSTRACT}

Because of China's recent economic success, the quality of life has greatly improved in Guangzhou, and high-rise housing has become the preferred housing style since the late 1990s. As products of modern, Western building technology, previous designs of high-rise housings by Chinese architects often reflect Western cultural themes. Missing from these designs is a strong neighbourhood environment, an important part of Chinese culture. This should be incorporated into Guangzhou building structures (based on Western building technologies) so that they can provide more comfortable and warm neighbourhoods above the ground, environments that better reflects Chinese culture and tradition.

Through an extensive interview survey conducted in Guangzhou, a map of Guangzhou neighbourhoods was drawn and three main variables about neighbourhood were analyzed: residential quality, neighbourhood features and residential evaluation. Next, the different characteristics of traditional Chinese neighbourhoods in Guangzhou are reflected in a hypothetical building design. Importantly, this design pays close attention to economical feasibility, in order to insure that it could be accepted by the market. 


\section{ACKNOWLEDGMENTS}

I would like to express my gratitude to my supervisor, Dr. Bruce Firestone, for his guidance and support. His advice and effort in directing my thesis have been of great help. His comments were always timely and relevant, and focused on my objectives.

I would also like to thank Professors Stephen Fai and Paul Kariouk. Their courses in the first year of graduate studies have proved invaluable and beneficial to my study. I am also grateful to all my friends in both Canada and China, whose support and encouragement made my studies at Carleton University very enjoyable.

Finally, I extend my heartfelt gratitude to my parents and my sister, for their unconditional support and love throughout my studies in Canada.

Wenxi He 


\section{TABLE OF CONTENTS}

ABSTRACT

TABLE OF CONTENTS iv

LIST OF ILLUSTRATIONS vii

LIST OF TABLES viii

\section{CHAPTER}

I. Introduction

1.1 Background.

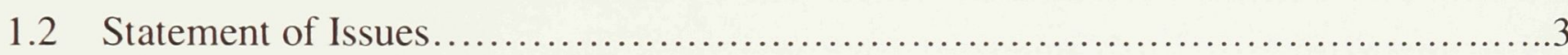

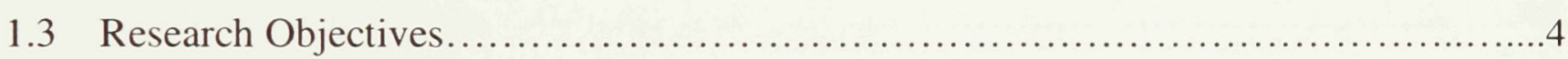

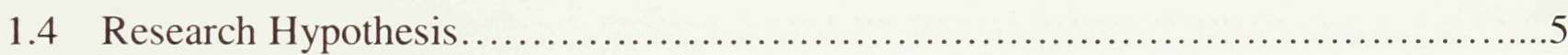

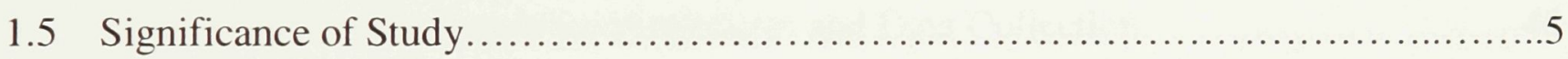

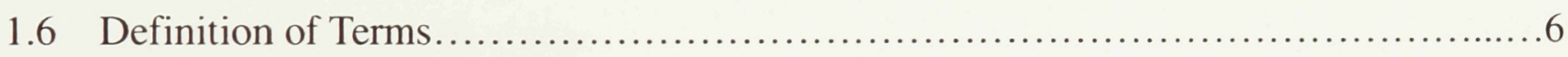

II. Literature Review

2.1 Conceptual Background

2.1.1 Neighbourhood Definition....................................................

2.1.2 The Impact of Urbanization on Neighbourhoods ..............................11

2.1.3 Neighbourhood and residential Satisfaction................................... 13

2.1.4 Neighbourhoods in High-rise Housing ............................................16

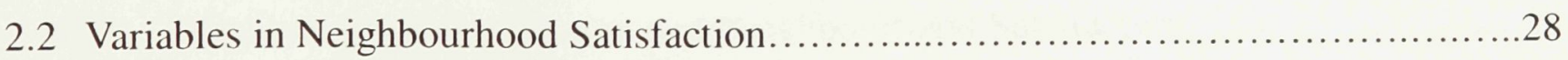

\section{Research Methodology}

3.1 Synopsis of Sample Area-Guangzhou 


\section{TABLE OF CONTENTS (Continued)}

CHAPTER

PAGE

3.1.1 Geographic and Climatic conditions .32

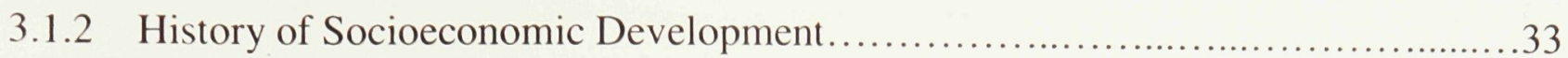

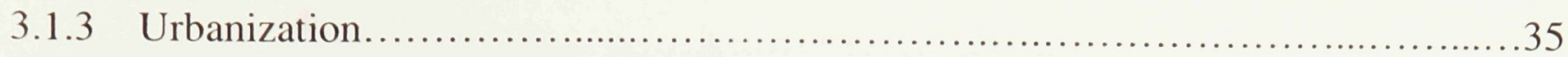

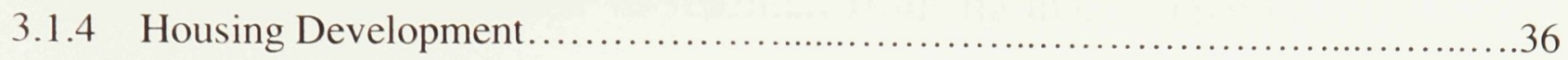

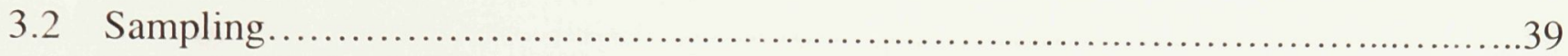

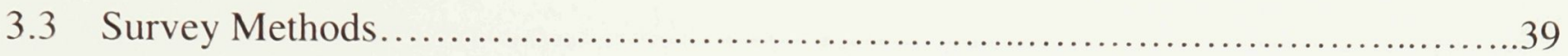

3.4 Variables

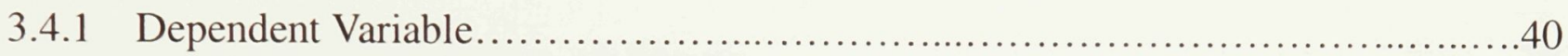

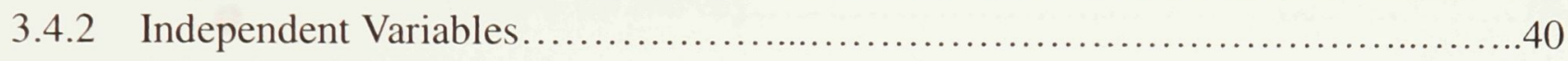

3.5 Validity and Reliability

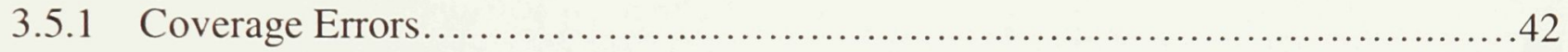

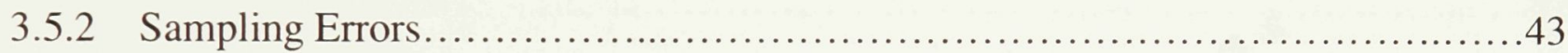

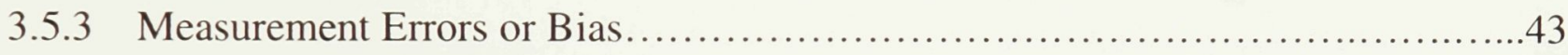

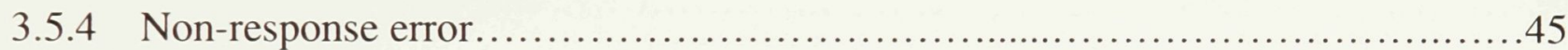

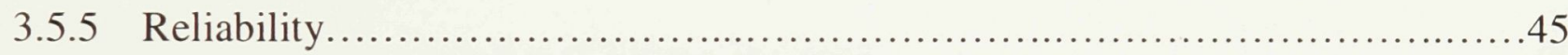

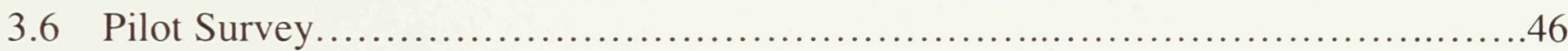

3.7 Questionnaire Administration Procedures and Data Collection.....................46

IV. Data Analysis and Results

4.1 Description of Survey Respondents and Housing Related Characteristics

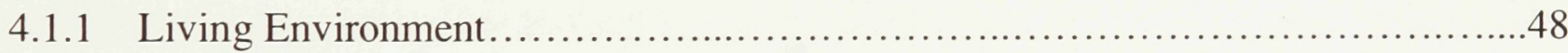

4.1.2 Description of the Respondents...........................................

\subsection{Discussion of Results}

4.2.1 Physical Quality of Housing and Neighbourhood Satisfaction.....................53

4.2.2 Neighbourhood Description and Neighbourhood Satisfaction......................54

4.2.3 Residential Quality and Neighbourhood Satisfaction..........................58

4.2.4 Respondent Characteristic and Neighbourhood Satisfaction......................59

4.3 The Neighborhood Satisfaction Model in Guangzhou.............................60 


\section{TABLE OF CONTENTS (Continued)}

CHAPTER

PAGE

4.4 Community Interests.

V. Concept Design: High-Rise Residential Housing in Guangzhou

5.1 Project Site 66

5.2 Design Principles 67

5.3 Concept Design .69

5.4 Economic Study and Follow-up Survey. .78

VI. Conclusion .82

BIBLIOGRAPHY. .85

APPENDIX A Survey Questionnaire .93

APPENDIX B Survey Questionnaire (Chinese Version). .99

APPENDIX C FOLLOW-UP SURVEY LETTER .103

APPENDIX D FOLLOW-UP SURVEY LETTER (Chinese Version). .104

APPENDIX E Correlate Matrix of Variables in High-rise Residences 105 APPENDIX F Correlate Matrix of Variables in Mid-rise Residences. 107

APPENDIX G Correlate Matrix of Variables in Low-rise Residences .109 


\section{LIST OF ILLUSTRATIONS}

Page

Figure 2.1 International Hotel Shanghai.... .21

Figure 2.2 Aiqun Hotel Guangzhou.

Figure 2.3 Modeling People's Feelings about Neighbourhood. 30

Figure 3.1 Illustration of Ancient Sea Coast Scheme. .32

Figure 3.2 The Location of Guangzhou Fosters Economic Growth. 33

Figure 3.3 Urban Sprawling Processes in Guangzhou. .36

Figure 4.1 Changes of Dwelling Area. .50

Figure 5.1 Selected Project Site and Location. 66

Figure 5.2 Typical Floor Plan (Original) .70

Figure 5.3 Typical Floor Plan (New) .70

Figure 5.4 New Concept Design Circulation Organizations . .72

Figure 5.5 Original Roof Design. .74

Figure 5.6 New Roof Garden. .74

Figure 5.7 Community Center. . .76 


\section{LIST OF TABLES}

Table 3.1 Description of Neighbourhood Satisfaction Variables used in the

Analysis .41

Table 4.1 Housing Characteristics and Tenure .49

Table 4.2 Housing Age and Style...... 50

Table 4.3 Characteristics of Respondents: Gender, Age and Family

Composition .51

Table 4.4 Characteristics of Respondents: Education, Employment and Household

Income .53

Table 4.5 Neighbourhood Satisfaction and Dwelling style....

Table 4.6 Tenure and Neighbourhood Satisfaction by Dwelling Style. 54

Table 4.7 Number of Known Neighbours. .56

Table 4.8 Gender and Safety in Different Dwelling Styles.... .56

Table 4.9 Annoyances and Nuisances in Different Dwellings

Table 4.10 Issues and Neighbourhood Satisfaction by Dwelling Styles .58

Table 4.11 Dwelling Factors and Different Housing Style.... .59

Table 4.12 Neighborhood Satisfaction: Stepwise Multiple Regression Analysis 61

Table 5.1 Economical Feasibility Study. .78 


\section{Chapter I}

\section{Introduction}

\subsection{BACKGROUND}

Since the founding of the People's Republic of China in 1949, the housing shortage in Guangzhou has been a critical issue for local government. There has been a slight change in per capita living area after a quarter of century, from $3.1 \mathrm{~m}^{2}$ to $4.2 \mathrm{~m}^{2}$ in 1980 (Ye, 1993).

Overcrowding is commonplace and most families do not even have a comprehensive housing unit. Sometimes, they need to share bathrooms or kitchens with other families. Families consisting of several generations often share an apartment; the young couples could rarely enjoy private space.

The lack of available land for housing purposes, and a vast population needing shelter-as of the end of 1980s, Guangzhou had a population of more than 5.9 million - are problems that require immediate solutions. Answers to the pressing questions of what kind(s) of housing will help to solve the shortage problem, and at the same time, improve living conditions, are needed urgently.

High-rise housing is an effective housing prototype that can provide more living space in areas where available land is scarce, and the government began using it as a housing type in the 1970s to relieve the housing shortage in Guangzhou. During the 1980s and 1990s, there was a remarkable increase in the construction of this housing type. High-rise housing currently accounts for a high percentage of total housing construction in Guangzhou, and its influence on 
the city, as well as on people's daily lives, is obvious. It has improved quality of living spaces, and it efficiently uses limited urban land resources. Furthermore, it has increased government investment in public transportation systems and related facilities. These benefits have earned it the approval of both developers and inhabitants.

However, past research done in North America has shown that high-density housing, and especially high-rise housings, has unfavorable effects on the well-being of residents. Alexander and colleagues (1977) studied the relation between the height of buildings and the frequency of mental disorder and social alienation. They found that because high-rise living took people away from the ground, and left them alone in their apartments, there was an increased chance of emotional breakdown. Mehrabian (1976) found that people living in single-family dwellings have a better mental health than those living in crowded high-rise housing. However, because most of the data for this research gathered from low-income families in public housing projects, it does not adequately reflect the conditions in contemporary Guangzhou. The lack of research concerning high-rise housing has represented an obstacle to addressing the urban reality in Guangzhou, especially with regards to neighbourhood design. Thus, residents' concerns in terms of physical, social, psychological and economic issues are easily overlooked by governments and developers. The objective of this study is to fill part of this research gap and evoke public recognition of design issues surrounding China's urbanization.

Certainly, the experience of high-rise housing differs among cultures and social classes, but the apparent similarities have resulted in various models of residential satisfaction and preference studies. In particular, a neighbourhood is an important research factor in these 
satisfaction models. The effects of "living off the ground" in a high-rise apartment impede recognition of the importance of traditional residential benefits such as place-identity or street neighbourhood, and these factors vary from culture to culture and place to place.

Housing quality should focus on both the physical quality of dwelling units and their psychological effects and perception because the evaluation of housing in its role as "home" cannot be merely based on physical satisfaction. High-rise housing has become a preference choice for most families in Guangzhou and it has had a different effect on society than it has in western countries. The study of a neighbourhood and its influence on high-rise housing needs involve residents from all social classes and economic levels, particular to the Guangzhou context.

Well-defined factors associated with residents' neighbourhood satisfaction will help establish the criteria used for evaluating the neighbourhood conditions for high-rise buildings. This study investigates whether contemporary high-rise design serves the needs of a healthy neighbourhood and vice versa. The recognition of the interaction of high-rise community and neighbourhoods will help to reshape the vertical neighbourhoods in Guangzhou dominated by the $21^{\text {st }}$ century high-rise.

\subsection{STATEMENT OF ISSUES}

High-rise residents in North America are mostly people who have a low income or those who are "empty nesters" leaving the matrimonial, single family home behind. The high-rise is looked on as a choice for young people at their beginning of work life circle, for new comers or for elders. 
The Metro Toronto Social Planning Council (1973) published a research result on families in high-rise apartment. In their study, they found that high-rise residents are generally young and in their early stages of the family cycle. The target populations of past studies on high-rise housing have been largely low-income residents, single parent families and elder residents with low incomes. Unfortunately, the context of this research is inappropriate to the Guangzhou situation. High-rise housings provide over 70\% of housing units in Guangzhou real estate market and play a crucial role in Guangzhou urban development. Not only do young, professional adults, but also middle-income households choose to live in high-rise residences. The most important thing is to investigate the adequacy of high-rise housing and eliminate any ill-effects through the design. Neighbourhood satisfaction, an important psychological indicator of residents' satisfaction and perceptions, is one of these issues that need to be studied immediately. This study identifies factors relates to neighbourhood satisfaction and examines personal characteristics as well.

\subsection{RESEARCH OBJECTIVES}

The specific objectives of this study are as follows:

1) to find out the level of neighbourhood satisfaction in Guangzhou;

2) to relate the level of neighbourhood satisfaction to different living styles, such as high-rise, multi-storey and low-rise;

3) to scrutinize the relationship between neighbourhood satisfaction and personal characteristics such as gender, age, education level, and income; and 
4) to propose some suggestions for architectural design in high-rise housing and anticipate the future of high-rise housing.

\subsection{RESEARCH HYPOTHESIS}

The study is based on a general hypothesis that contemporary high-rise housing design is not creating comfortable and close neighbourhood environments. In order to address the objectives of the study, the following hypothesis will be explored:

What is the reality of a neighbourhood environment in a rapidly urbanizing city? Are people living high off the ground satisfied with their neighbourhood environment? What can architect and planner do to improve or create a healthy vertical neighbourhood in high-rise housing environment? Are there differences relative to residential satisfaction with their neighbourhoods in terms of high-rise housing?

\subsection{SIGNIFICANCE OF THE STUDY}

The purpose of this study is to investigate vertical neighbourhood satisfaction among residents of high-rise dwellings in order to provide alternatives for the Guangzhou urban population in the future. Additionally, it examines whether personal characteristics will influence the neighbourhood satisfaction of high-rise housing.

As a consequence, an investigation of neighbourhood satisfaction provides an opportunity for evaluating the positive and negative effects of high-rise apartments. If there are 
no negative impacts on the well-being of middle class residents, the negative views of high-rise housing on humanistic grounds should be reconsidered. On the other hand, the demographic characteristics of these residents may indicate particular needs. The results of this study may also provide design professionals with useful information to develop better design practices for high-rise dwellings.

\subsection{DEFINITION OF TERMS}

The following definitions are used in this study:

High-rise apartments: High-rise apartments are defined as residential buildings over nine stories.

Mid-rise apartments: Mid-rise apartments are defined as residential buildings between four floors and nine floors.

Low-rise apartments: Low-rise apartments are defined as residential buildings lower than four floors.

Single-family house: A single-family house is defined as a permanent and detached structure that provides completely independent living facilities for living, sleeping, eating, and sanitation.

Duplex apartment: An apartment having rooms in more than one floor that are connected by an interior staircase.

Socio-demographic-economic characteristics of residents: Characteristics include information about gender, age, education, family composition, occupancy, ownership, income-level and length of residency in the present dwelling. 


\section{CHAPTER II \\ Literature Review}

\subsection{CONCEPTUAL BACKGROUND}

\subsubsection{Neighbourhood Definition}

Words that are the currency of everyday conversation tend to become stretched so that they

embrace a wide rage of meanings. Neighbourhood is such a word. It is widely used, but it means different things to different people. To some, it simply implies a subdivision; to others, a small urban area centered on a traditional main street. There is no consensus among either residents or scholars on how to define neighbourhood. It can be conceptualized in different ways and characteristics. Different definitions reflect the various purposes for which the concept is used. Neighbourhoods are essentially created by residents and they do not necessarily have a name or official status. The definition of neighbourhoods can thus vary from place to place and they are more descriptive than normative.

A neighbourhood's definition often depends on the geographic scales used by the residents. In 1915, Robert E. Park and E. W. Burgess introduced the idea of neighbourhood as an ecological concept with planning implications. In their work, neighbourhood consisted of physical features: land use, density, street patterns, "natural" boundaries and open space. Hallman (1984) describes a neighbourhood as a geographical concept, a small area within large settlement. Specifically, a neighbourhood is a limited territory within an urban area where people inhabit dwellings and interact socially. Neighbourhood is a sense of containment, formed by 
boundaries such as expressways, railroads, parks, churches, stores, streets, sidewalks, rivers, ponds, lakes, changes inland use, public transit, etc.

Social planners and sociologists define neighbourhood based on social dimensions. To them, the characteristics of a neighbourhood are determined by its cultural and social aspects and created by shared activities, experiences, social groups, common values and loyalties. A neighbourhood is a subjective entity rather than an objective reality. People use different variables and figures to value and judge the neighbourhood even in the same household. The physical environment is often taken for granted by sociologists. For example, P. H. Mann (1965) said that the physical aspects of neighbourhood were sterile, unrelated to the social aspects and therefore not useful.

Some scholars have suggested a unified definition that combines both physical and social aspects of neighbourhoods. In England, Ruth Glass (1964) believed that neighbourhood can be defined both as a territorial group with close social interaction and an area with physical characteristics. Terence Lee (1970) proposed that urban neighbourhoods are defined as a socio-spatial schema, a definition that most clearly combines the social and physical features of a neighbourhood. Terence's and Glass' work gives a more comprehensive view of neighbourhood and many planners, designers and social scientists have followed their lead, defining neighbourhood as the relationships between physical and social aspects.

John McClaughry (1980) also used similar elements in his definition: (1) community institutions, such as churches, police and fire stations; (2) neighbour groups; (3) neighbourhood activities and identity. Suzanne Keller (1968) studied the literature of sociology and city planning 
on neighbourhood. She used four factors to address the distinctiveness of neighbourhood: (1) geographical boundaries; (2) characteristics of inhabitants; (3) psychological unity among people who feel that they belong together; and (4) concentrated use of an area's facilities for shopping, leisure, and learning. Keller knew that these four factors seldom coincided in modern cities at the same time. The definition of geographical and personal boundaries is vague or changed according to each resident. But the definition of neighbourhood seems to come from the union of geographical and sociological concepts.

Hallman (1984) understood the meaning of neighbourhood based on its various functions. Neighbours create a collective life carried out through social networks and sets of institutional arrangements; a neighbourhood can provide for the fundamental human need of shelter, and also the enhancement of life through schools, playgrounds, parks and recreation centers. A neighbourhood can be perceived as a little economy, which structures the inhabitants' daily lives through buying and selling. A neighbourhood is also a political community. Ahlbrandt and Cunningham (1979) define neighbourhood as a service area, a provider of shelter, a political force, an actual or potential level of government and a market.

Neighbourhood may be seen as a source of place-identity and a cell of urban decision making. The definition of neighbourhood in this thesis concentrates on place identity, and different ways of satisfying various residential functions. All people, no matter who they are or where they live, need to satisfy similar residential functions, such as shelter, security, and recreation; that is to say, there are certain universal themes that make each neighbourhood what it is, for example, residential quality, community security and etc. The criteria for good housing 
should have a rough consensus of neighbourhood requirements. Richman (1979) identifies housing functions as satisfying the need for shelter, security, childrearing, symbolic identification, social interaction, participation and recreation. People tend to equate the concept of housing with that of houses, designing their dwellings to meet all the residential requirements. This temptation proves futile without the consideration of an important subjective factor: human relations in agglomerations called neighbourhoods.

The difference between housing and neighbourhood exists in the complex interaction of human relations. Houses provide for physical requirements-they are containers for people's lives, which meet the objective of shelter; on the other hand, complex social networks and relationships give residents their spiritual and emotional satisfaction. The neighbourhood can be seen as a combination of all these functions. A good neighbourhood is a supplement and enhancement to the home environment. For example, a neighbourhood day-care center increases the range of domestic activities and compensates for a shortage of play space at home; neighbourhood delicatessens, restaurants, and laundries cut down on housework and compensate for a lack of household help. A safe neighbourhood gives residents shelters from unwanted outside intrusions and criminals; children, single people, and elders can feel peaceful and secure within their neighbourhood boundaries. Public transportation close to the neighbourhood provides a connection to the other parts of the city and compensates for the lack of private methods of transport. A quiet neighbourhood park extends peace and leisure outside the home. In these examples, restaurants, laundries, parks, day-care centers, and streets serve as extensions of the house and help it to become an ideal housing unit - a home connected to its neighbourhood. 
Creating a vertical neighbourhood is an attempt to add these traditional values into the new housing setting (i.e., high-rise structures) and establish a new place identity and make it a home.

\subsubsection{The Impact of Urbanization on Neighbourhoods}

During and after World War II, millions of relatively poor households ones migrated from rural areas into large cities and the population soared. It thus became necessary to furnish moderateand middle-income households with larger and higher-quality housing as their families grew and their real incomes rose. These demands led to the rapidly increasing number of housing units, and improvements in the quality of the housing inventory. Since the process had to operate largely through markets where choices by individual households were voluntary, it had to carter to certain strong desires held by those households - to have enough living space, to have sufficient access to public services, to own automobiles and to live in neighbourhoods that were relatively homogeneous both socially and economically. Not all of these desires were achievable, but they were all strong enough to affect urban growth patterns.

Social scientists have offered polar positions on this issue. Louis Wirth (1938) brings together various threads of reasoning in his paper "Urbanism as a Way of Life." This paper is an influential contribution to the topic of urban life, and has stimulated both empirical research and controversial speculation to this day. Wirth defines the city as characterized by its relatively large size, high density, and social heterogeneity, and he discusses the influence of these three features on social as well as individual life. He came to the conclusion that the urban mode of life "consists of the substitution of secondary for primary contacts, the weakening of bonds of 
kinship, and the declining and the undermining of traditional basis of social solidarity" (pp.20).

Wirth's theoretical definition left people socially uprooted and politically powerless, conditions

which are lessened only when urbanites are willing to submerge their identity in a mass

movement. Contemporary urbanizing destroys previously intimate communities, family authority

and solidarity based upon common experience and their functional interdependence; conflicting

and contractual relationships replace the above. Existing communities are obliterated and mass

society becomes a society of undifferentiated humanity.

On the other hand, some social scientists would challenge this argument. Fischer (1982)

claims that rather than breaking down social ties and releasing people's deviant instincts,

urbanism encourages social ties within small sectors of society and lifestyles that mainstream

society considers aberrant may arise. Urban subcultures or communities give birth to new ideas

and styles, nurture them, and send them out into the rest of the world.

The urbanizing process is not consciously designed by people or groups; it is an evolving

process that responds to meet residents' various requirements. Separate decisions made and actions taken by millions of households, local governments, federal agencies, home builders, lenders, developers and politicians create the urban ecology. Sometimes, it succeeds in providing high quality housing and excellent residential environments for a majority of households in metropolitan areas. To seek a better quality of life, architects and designers need to impact the patterns of urbanization: the size of cities, the distribution of population within the metropolis, dwelling designs, and so forth. Moreover, it is essential that they learn about what is an optimum density for a cultural enclave in a city (Hall, 1969). Achieving balance among the physical, social, 
and economic aspects of a community is the goal.

\subsubsection{Neighbourhood and Residential Satisfaction}

A residence is a basic requirement for the well-being of individuals and families. When we talk about a residence today, it is not only a place that provides shelter and protection from the elements but also expresses one's social status and is a demonstration of values. Housing is associated with economic, aesthetic, physical value and environmental psychology. Rapoport (1980) criticizes the tendency that housing has been interpreted as a product (or even a commodity), as a process, as a place (including concepts related to expression of identity, self-worth, and status), a private domain, or solely in terms of functional requirements. Instead, housing should be thought of as a group of components which coordinate to achieve a set of goals. These components can take different forms, such as physical structure and its environment; the residents, managers, developers, architects and other entrepreneurs; the social and political organizations; the cultural characteristics; and so on.

As a result, what a person seeks and is satisfied with in a house is an expression of his or her basic value system. Canter and Rees (1982) suggest that housing satisfaction can be construed as "a reflection of the degree to which the inhabitants feel their housing is helping them to achieve their goals" (p.200). Therefore, housing satisfaction can ultimately be an indicator of a value system. Determining which components of the housing system most strongly and consistently predict residential satisfaction is perhaps more useful as a guide for action because it can be used to direct efforts in those directions and to yield the most beneficial effects. 
A residential satisfaction model thus acts as a way to represent and investigate understanding what residents perceive as desirable. For her model, Smith (1994) selected a suitable physical structure, social relationships, self-expression, continuity, privacy and personal identity as the essential qualities of a home. Moreover, she found that there are gender differences in people's evaluation of housing. For example, security and a sense of place are more important for women than for men. Despres (1991) defined the following functions of home and residence: the reflection of one's ideals and values; security and protection from the outside world; the ability to control and modify one's dwelling; its use as a center for family or social relationships; permanence and continuity; a representation of personal status; and a place to own. Lawrence (1987) studied the meaning and use of home regarding the interrelations of existing cultural, socio-demographic, psychological dimensions and the organization of spaces and activities.

Thus, the evaluation of housing factors, affects having the preferences of which come from a household's complex set of beliefs and expectations. Households, which have a high degree of local identification strengthened by strong social interactions, will choose this factor as an important determinant variable of satisfaction. Riger (1984) concluded that people living in a place where neighbours are willing to greet and visit with each other have higher sense of social belonging and reduced feelings of isolation that are often fostered in cities. On the other hand, a 'cosmopolitan' household which lacks place identification and community experience will be less sensitized to local issues and problems.

Different studies of housing and housing characteristics have reached the common conclusion that neighbourhood characteristics deserve careful consideration in determining the 
overall measure of residential satisfaction. In an interview survey, Fried and Gleicher (1961) found that a sense of identification with local places was especially high in persons who experienced satisfaction from living in a particular territory, and is closely related to community interaction with local neighbours. Festinger (1950) emphasized that community organization affects one's value system and behavior. Some studies have concluded that neighbourhood satisfaction is the most important component of overall housing satisfaction. For example, a study carried out in the West End of Boston prior to urban renewal found that many "West Enders" continued to remain in overcrowded or otherwise unsatisfactory housing units, even when they could afford to move to better quality housing, because they had a strong attachment to their neighbourhood, which afforded many opportunities for frequent interaction with neighbours, friends and relatives (Hartman, 1953).

In 1947, the first redevelopment project proposed for the city of Milwaukee was defeated by residents. One woman stated in The Milwaukee Journal: "Slums, they call us. Why that's a terrible word - those are our homes, our shrines. We live there" (Woodbury, 1953). The inertia, not to say intransigence, of those "slum" residents who resist being moved in one city after another makes it plain that they do not view their surroundings with the same contempt as city planners and municipal officials. In the words of a study do in the Chelsea area of New York: Housing ... has represented much more than physical structures. Housing is/has become a subject of highly charged emotional content: a matter of strong feeling. It is the symbol of status, of achievement, of social acceptance. (Hudson Guild, 1960)

Despite the fact that their residences had many obvious physical inadequacies, residents of the 
project expressed general satisfaction with their homes and their community, largely because they participated in an active community life. Through social activities, people develop a social network and feel a part of the larger social structure, which eventually augments their residential satisfaction. Although the physical quality of the housing may be adequate, people will likely be dissatisfied with their residence when social interaction does not fulfill peoples' needs and preferred lifestyle. In the typical "American Dream", a desire to live in a "better" neighbourhood, defined in terms of more amenities, a better community, and the presence of more "socially desirable" types of people, has been identified as an important reason for movement from the city to the suburbs, especially among upper-income groups. Now, people are rethinking whether the suburban neighbourhood in the suburbs is better than the urban core. This reconsideration leads to urban revival and the comprehensive evaluation of vertical living.

\subsubsection{Neighbourhoods in High-rise Housing}

\subsubsection{The History of High-rise Housing}

The tendency to "rise above the self" by building is a fundamental human urge. Building into the sky satisfies a primeval instinct. Acted-out collectively, it signifies the desire to dominate and for danger. Where such instincts are involved, incommensurables invariably appear. (Burckhardt, 1949)

High-rise apartment buildings, a product of modern patterns of living and building technology, first appeared at the end of the nineteenth century. The emergence and development of high-rise housing came from advances in architectural theory and practice, and at the 
beginning of twentieth century, architects and developers realized the huge potential existing in this industrial dwelling model. In the early 1920s, Walter Gropius was among the first to consider the rational height of working-class housing in urban areas. He suggested a new site plan, which consisted of rows of ten to twelve storey rectangular slabs, which had eight times the building width distance between each other. In Gropius's opinion, through raising the floor area ratio and limiting the number of buildings, residents could have more open green space than before. In 1929, he argued that the best housing forms were either single-family suburban houses or the 10-12 stories high-rise residential buildings "in localities of high land utilization" (Housing Study Guild, 1935).

Le Corbusier entered the debate of high-rise living after his study of the high-rise apartment and traditional horizontal designs in the 1920s. Later he chose the vertical building as a subject in his famous urban plan-the vertical garden city. His objective was to relieve the crowding of urban areas and build modern residential towers with maximum access to light, fresh air and view. The "tower in the park" — the notion of freestanding high-rise residential buildings in park-like settings — was a theory that gained widespread interest in the middle decades of the twentieth century. The popularity of this theory was due, at least in part, to the fact that it "conformed to the desire of reducing costs and coverage in social housing". And "from the point of view of the architects... the 'tower in the park' was legitimized as a progressive vision by its association with European theory, especially with Le Corbusier" (Plunz, 1990).

Unfortunately, there were seldom the landscapes or parks built around the high-rises as people had hoped. Too often the spaces between high-rise structures became 'no-places' filled with 
garbage, destroyed furniture and dominated by criminal elements especially at night. This "ideal" living model was often criticized by its residents after World War II.

Early nineteenth-century high-rise apartment buildings in America had little communal space, and were divided into numerous, poorly-lit units. Forced by legislation dictating minimum standards for light and ventilation, developers sometimes built interior courtyards to solve these problems. In the early 1920s, government and building professionals agreed that an "altogether new urban pattern" based on courtyard apartment buildings seemed to be a good way to solve the problems of illumination and ventilation, and provide public and green space (Mumford, 1995). New architectural ideas, such as "towers in the park," derived from Europe in the second and third decade of the twentieth century soon became popular in America. The "River Garden", a housing project designed by George Howe and William Lescaze and built in Manhattan 1932, was one of the first large-scale "tower in the park" projects.

High-rise construction did not develop into a large-scale enterprise until the 1960s. After twenty years, the world had recovered from the damage of the W.W.II. Because of the baby boom and the rapid urbanization of the late 1950s, urban population steadily increased and a housing shortage became an increasing social problem.

In the Netherlands, more than 60 percent of the approximately 350,000 high-rise apartments (about 10 percent of the housing stock) were built in a relatively short period, from 1964 to 1974 (Rossum et al. 1981). Also, in England and North America, a high-rise housing boom took place during the same period (Cooney 1974). By the late 1970s, $99 \%$ of the population of Madrid, Spain $(3,000,000)$ lived in apartments averaging 8 to 10 stories, and $75 \%$ 
preferred high-rise living. Samuel Paul (1967) gives several reasons to explain this phenomenon: first, the growth of the urban population and the increasing number of young adults and older people in the composition of the urban population; second, the economic benefits for landlords who could increase profits by having more residential space for rent or sale; third, the novelty and benefits of a "bird's eye-view" of surrounding areas was available to a greater population; fourth, high-rise apartment buildings allowed more of the site to be given over to open space and, supposedly, a more pleasant living environment. Moreover, high-rise housing was considered practical for low-income housing projects and slum redevelopment around the world.

Due to lower marriage and birth rates, the overall demand for housing in the developed countries declined in the 1980s and 1990s. This was moderated to same degree by decreases in the average dwelling unit accompany rate. After two decades of decline, high-rise housing returned to center stage once again. Richard Kateley (1988) posits some reasons that led to this change in America: the American economy had been transformed from an industrial manufacturing to a service economy; most employment opportunities were still being created in downtown areas; younger generations showed a preference to live close to their work place and they enjoyed varied and colorful urban life. Higher income-levels resulting from a booming economy made it possible to provide high-quality, high-rise housing as family sizes became smaller. Also the number of single parent and DINK (Double Incomes, No Kids) families increased, which created more potential residents for high-rise housing. At the same time, urban revitalization projects increased people's interest in downtown living and many senior citizens wanted to live in high-rise housing. Since the typical American dream of living in a single-family, 
suburban house was not affordable for many families, high-rise housing was seen as providing a reasonable alternative.

High-rise living has become part of some megacities, such as New York, Chicago and Madrid. After several decades of debate on the success or failure of high-rise housing, people are beginning to stand back and look at this housing type objectively. Alan Ritchie (1988) has pointed out: "The swing in taste and style is as predictable as night and day, and we are at this very moment busy rewriting the rules of ... design. In the process we are not sure that the right lessons we have learned are not being discarded for the wrong ones" (pp.3). The number of high-rise residents will keep on increasing in the world and this trend will continue for a long period. The objective here is not to discuss whether the existence of high-rise housing is wrong or right but to find out if there are better criteria for high-rise design, which can make it more humanistic and responsible to society.

\subsubsection{High-rise Housing in China}

The history of the skyscraper in China is very short. Before the liberation in 1949, less than 20 high-rise buildings existed in the whole nation. These buildings were mostly used as government office buildings or high-class hotels, designed by Western firms. The highest Chinese building before 1949 was the Shanghai International Hotel built in 1932, which has 24 floors and is $83.8 \mathrm{~m}$ in height (Figure 2.1). In Guangzhou, the Aiqun Hotel was the highest building, which was completed in 1937. It stands $64 \mathrm{~m}$ high and has 15 floors (Figure 2.2). These buildings were symbols of social and economic status for masses. 


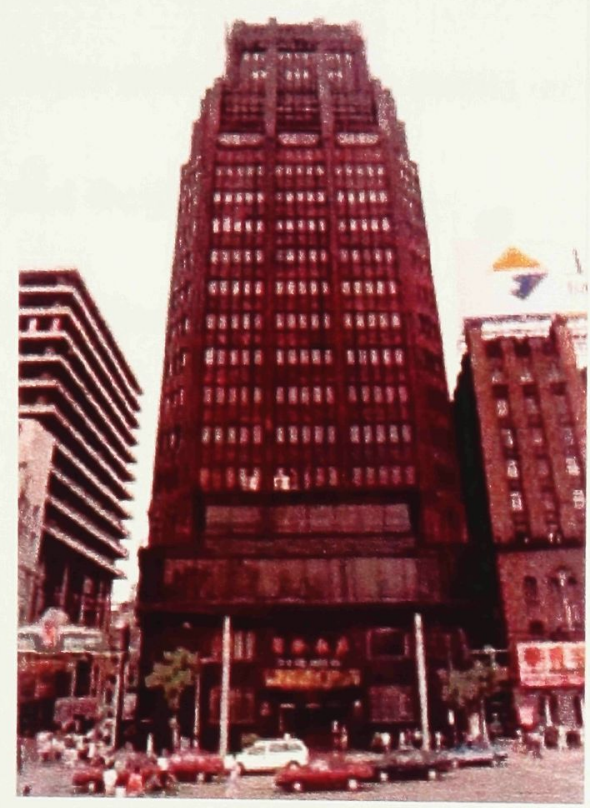

Figure 2.1

International Hotel

Shanghai (1932)

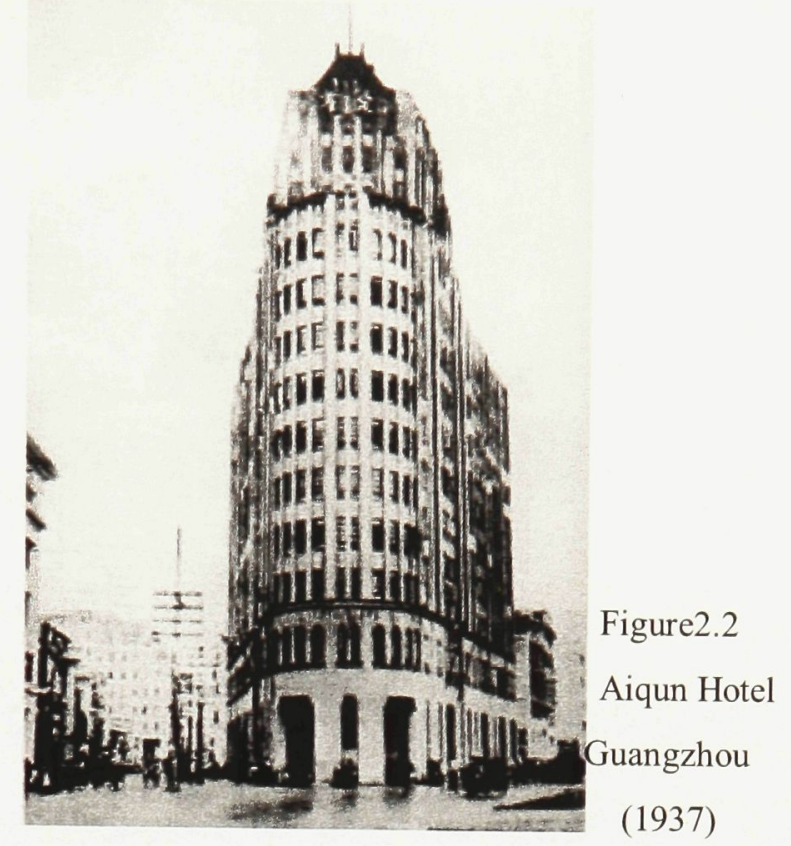

Due to high construction costs and lack of a modern steel industry, high-rise buildings did not change much before the 1970s. High-rise buildings during these decades were all used as hotels, which only hosted foreigners. Living in a high-rise building with an elevator was still an inaccessible dream for most Chinese at that time. Due to an extreme housing shortage, high-rise housing was finally used as a mass solution during the 1980s, providing accommodations in Chinese megacities, such as Beijing and Shanghai. The completed building area of high-rise housing was only $0.3 \%$ of total housing construction before 1976 , but it increased to $33.7 \%$ by 1985 (Fan, 1988).

Implementation of the "Open Door" and "Economic Reform" policies greatly propelled social and economic development during the 1980s and 1990s. The process of urbanization was inevitable and the urban population increased dramatically; the housing shortage problem thus became more acute. At the same time, a lot of advanced construction techniques and equipment were imported from Western countries, which helped solve the problem by immediately 
increasing the production of high-rise units. High-rise building projects quickly sprouted in many cities and skyscraper mania swept cities throughout the country—-from Shenzhen to Shanghai and Beijing. Currently, there are over 1,500 high-rise buildings greater than $90 \mathrm{~m}$ built in mainland China (Gramsbergen, 2004). In only twenty-five years, the number of high-rises in mainland China has equaled that of America, which was the birthplace of the modern skyscraper. After the terrorist disaster happened in New York on September $11^{\text {th }} 2001$, some western investors began to reconsider the number of storeys and height of skyscrapers in downtown areas and re-estimate the rationality of those skyscrapers. However, this event had no effect on cooling down Chinese high-rise fever. It seems high-rise buildings will continue to be one of the main building types for China in the near future. Wenjiao Shan (2004) gives five reasons to explain the cause of the popularity of the skyscraper in China: urbanization, changes in economic policy, prosperity of the market, imported cultural and technological advances, and the popular association of high-rises with Western civilization (pp.51-55).

\subsubsection{The Polarized Attitude toward High-rise Housing}

After World War II, the flourish of high-rise housing in the West finally leaded to a development trend, which began in the late 1960s. In order to shorten the construction time and create maximum profit, developers designed and built multi-family housing using mass-production methods, such as standardized units, flat-roofed visual uniformity, and the increasing use of inexpensive industrial materials. In addition to technical problems, the social climate in some of those buildings was viewed as a disaster. Vandalism, public nuisances and the lack of social 
control affected residential satisfaction in these buildings. Vacancies, rent arrears, and a high turnover rate depressed financial returns of high-rise housing. The "Piggeries," a nickname for some near-derelict apartment buildings in Liverpool, were sold to a developer for next to nothing, and the Pruitt-Igoe project in St. Louis was blown up only 18 years after completion, an example that by now is not an exception any longer (Dunleavy 1981; Ravertz 1985). The literature cites the excessively large concentration of problem families in badly designed and poorly maintained high-rise buildings as the cause of the deterioration (Bourne 1981; Rainwater 1966; Yancey 1971).

Michelson (1968) reports that $85 \%$ of urban residents prefer to live in single family homes rather than in an apartment. Over $66 \%$ of residents in multi-family housing also preferred the single-family detached house. Michelson's research done in 1977 proved that mixed socio-economic populations residing in various types of housing possessed the same attitude toward single-family housing. This means that high-rise apartments are not accepted as an ideal form of housing. The Bijlmermeer, a high-rise housing project in Amsterdam, had a constant vacancy rate over twenty percent during the 1980s (Kempen, 1987). Once this project was thought to be "the city of future," an ideal city concept directly inherited from Le Corbusier and CIAM. The idea of this project has proven to be too academic and sterile today.

Homenuck and Schindeler (1974) describe four main factors that may explain the rejection of multi-family housing and the high-rise apartment: (1) a resistance from those who view the growth of cities (where tall buildings are thought to be a manifestation of crowded and congested conditions) as a threat to an agrarian, rural society; (2) a perception of the 
single-family house on private lots, as symbolically valuable in terms of personal and social status; (3) a cultural value of middle-class parents' belief in the independent rearing of children including the free expression of children, their socialization, and creative play; and (4) people's tendency to relate the image of high-density housing with apartments for low-income families, which is associated with a high incidence of social problems and physical deterioration.

Kempen (1987) analyzed four inherent factors related to high-rise housing rejection: proximity, which includes the diversity of residents; congestion of public services; a sense of anonymity and lack of social control; and a lack of feedback. Haber (1977) studied a random sample of 300 undergraduate students from different majors at Maryland University. From the survey, he identified several reasons that influence people's attitudes towards tall buildings: waiting for elevators, missing greenery, the fear of fire, and their impersonal characteristics.

The criticisms of apartment housing, according to Wagner's article (1991), can be divided into two general types: (1) insufficiencies and inadequacies in the design, layout and general physical condition of existing apartments; (2) negative social effects from experiences, such as the loss of individuality, juvenile delinquency, or conspicuous consumption.

Previous designs of high-rise apartment buildings, both public housing and private luxury condominiums, are often homogeneous, architecturally ordinary in appearance and type. The replication of high-rise design becomes representative of low-income housing. High-rise buildings are limited with respect to what they can provide for different age groups and brackets, and incomes. People are often left isolated, prevented from meaningful interaction. Traditional neighbourhoods often can provide this, but high-rise dwellings often lack of chances and 
locations, prevent the establishment of place identity, and generally lost neighbourhood feeling. High-rise housing has often been viewed as second-class housing by tenants, people who live adjacent to them in single-family neighbourhoods, and developers, who tend to view these developments as investments, not homes (Dreier, 1982). Dreier's conclusion clearly defines the common feeling about high-rise housing.

Approximately fifteen percent of the dwelling units in America are multi-family units constructed in the 1980 s and over thirty-five percent of households live in multi-family buildings. Though people prefer single-family houses as their permanent residence, some urbanites will choose to live in apartment building during parts of their life cycle, such as pre-family, post-family, or as childless adults. Also, the change of family composition and economic structure is seen as an important catalyst to the number of tenants.

There is some research that speaks to the positive effects of high-rise apartment living. Mackintosh (1982) studied middle-income households who chose high-rise apartments as their residences in New York City. From the study, she found that the residents' satisfaction comes from good building design and management. Ramirez (1981) found that some people living in high-rise buildings believed them to be efficient use of land resources, saving housework and maintenance time, and safer than other forms of housing. In addition, residents did not feel a strong impact of negative issues, such as noise, over-crowding, or lack of social contact while living in their condominiums. Greenberg and colleagues (1977) found that the higher the floor, the more residents perceived their apartments as being quiet, private, efficient, secure, conductive to studying, convenient, and functional. This research provides positive support for 
the development of high-rise dwellings.

The attitude towards high-rise housing can be either positive or negative. This debate has lasted over a century and become part of high-rise housing's history. No matter the final answer of this debate, the proportion of high-rise housing will continue increasing in most Chinese cities, such as Beijing, Shanghai, and Guangzhou. Solving the negative issues will be a crucial issue for contemporary Chinese design of urban development.

\subsubsection{Neighbourhood and High-rise Residential Satisfaction}

Housing not only provides a sanctuary from the natural environment, but also acts as a place to raise children, and a place to rest and relax. Nearly one third of human life is spent at home. Therefore, it is obvious for individuals and households to be satisfied with their housing environment. Satisfactory housing can produce a multiplicity of psychological, social and physical benefits, which are necessary for a healthy, productive life. A realistic way to study residential satisfaction toward high-rise apartment housing is to investigate the values and attitudes toward different urban residential environments. Finding out the specific issues which are correlated to residential satisfaction can become the foundation of future planning and design (Weidemann et al., 1982).

Obviously, residents of high-rise housing regard their neighbourhood environment as their dwelling unit. Neighbourhood becomes one of the essential indicators of residential satisfaction. Taylor (1993) indicates that when satisfaction with a residence is separated from satisfaction with the neighbourhood, there was more dissatisfaction expressed concerning the 
neighbourhood than the home. Neighbourhood, as an agglomeration of groups and social networks, develops from social interaction, competition, cooperation, and integration. Through social interaction, such as borrowing or lending tools, daily greeting, and asking for help in an emergency, neighbours provide each other with emotional, informational and often support (Unger and Wandersman, 1985). Neighbourhood relations serve as a support system for individuals, fostering a sense of identification and functioning as a buffer from the feelings of isolation often associated with modern apartment living. Indeed, social interaction among neighbours often complements a person's informal social network that exists outside of his or her residential environment. Moreover, these informal social activities appear strongest and most important in neighbourhoods in deterring organized crime, vandalism, robbery and the deterioration of the physical environment (Perkins et al., 1990). The most frequent social interaction among high-rise residents is conversations in common areas, such as elevator lobbies, fitness rooms, and green spaces. These places thus become the focal point in high-rise neighbourhood design.

However, there are some issues affecting the social interaction of neighbours, such as high turnover rates, a diverse socio-demographic composition of residents, a high percentage of employed women, and a lack of communal space. In housing with a large and transient population, social activities with neighbours are generally either rare or totally nonexistent (Michelson, 1970). Though people have intense interest in interacting with one another, they often do not have much of a chance to do so-perhaps the location to mix with their neighbours is absent or the time is not available. Those in the lower socio-economic classes feel especially 
isolated from the mainstream (Frankenberg, 1977).

In an empirical study on neighbourhood in an urban environment, Unger (1982) asserts that the extent of the neighbourhood to which a person contributes is closely related to the socio-psychological environment of the neighbourhood block. Unger's procedure identifies that the psychological sense of community, the satisfaction with neighbourhood conditions, and participation in neighbourhood activities were the main attributes that indicate the satisfied level of neighbourhood. Neighbourhood patterns among high-rise residents can be summarized as follows: chats in apartments and common areas, sports and games with fellow residents, participation in neighbourhood activities such as parties and organizations, sharing a sense of community (i.e., sharing common interests or concerns). These are the main indices measuring the level of neighbourhood which of course, is strongly associated with residential satisfaction and serves as one of the main functions of the home.

\subsection{VARIABLES IN NEIGHBOURHOOD SATISFACTION}

Previous studies prove that a high level of neighbourhood satisfaction can lead people to overlook inadequacies in their own home environment, even if those inadequacies are severe. In order to satisfy housing consumers on a long-term basis, designers and developers should devote as much attention to neighbourhood features as to the design of the housing unit itself. Of course, both 'neighbourhood' and 'satisfaction' are subjective issues. Therefore, it is impossible to determine the key elements of neighbourhood which fit all circumstances. Neighbourhood preferences can thus vary according to a number of factors, including social class, gender, 
education, and stage in the life cycle. Different groups have special requirements for neighbourhood development. If the housing developers want to increase this satisfaction, they should consider the wide range of demands by housing consumers.

Brower (1996) identifies the qualities which are most strongly associated with good neighbourhoods—-he cites into three dimensions: 'Ambience', 'Engagement' and 'Choicefulness'. 'Ambience' represents the nature, mix and intensity of land uses, and the appearance and form of the physical environment. The qualities related with 'ambience' are management, a comfortable and relaxing atmosphere, and proximity to a convenient transit system. 'Engagement' refers to the nature and extent of interaction among residents and the presence of facilities and features that foster or inhibit these interactions. The factors associated with 'engagement' are safety and security, convenient social services (i.e. restaurants, stores and cultural and sport facilities), openness toward newcomers, friendly neighbours, and suitability for settlement. 'Choicefulness' can be seen as the opportunity for residents to choose alternative locations, lifestyles, and living arrangements. The neighbourhood qualities that scored high on the 'Choicefulness' dimension are a desirable reputation, similar social classes and life-styles, the isolation of social problems, and appropriateness for raising children. In addition, Brower also emphasizes the importance of the characteristics of the residents, such as income and gender, all of which influence the evaluation of a neighbourhood.

Ahlbrandt and Cunningham (1979) show that residents' affective sentiments toward their neighbourhood (their commitment toward it and satisfaction with it as a place to live) are associated with the social fabric of the neighbourhood, the quality of life, the use of 
neighbourhood facilities, the sense of community felt by residents, and their overall satisfaction with their housing (Figure 2.3). After conducting a telephone survey of nearly 6,000 Pittsburgh residents, Ahlbrandt (1984) divided the variables of neighbourhood satisfaction into three major groups: quality of life, social fabric and respondent characteristics. Three variables, including the use of neighbourhood facilities, satisfaction with housing and satisfaction with public services, related to quality of life. The variables defined in social fabric include the number of good friends living in the neighbourhood, participation in neighbourhood activities, and so forth. Respondents' characteristics are age, income, homeownership, race, family composition and length of residence.

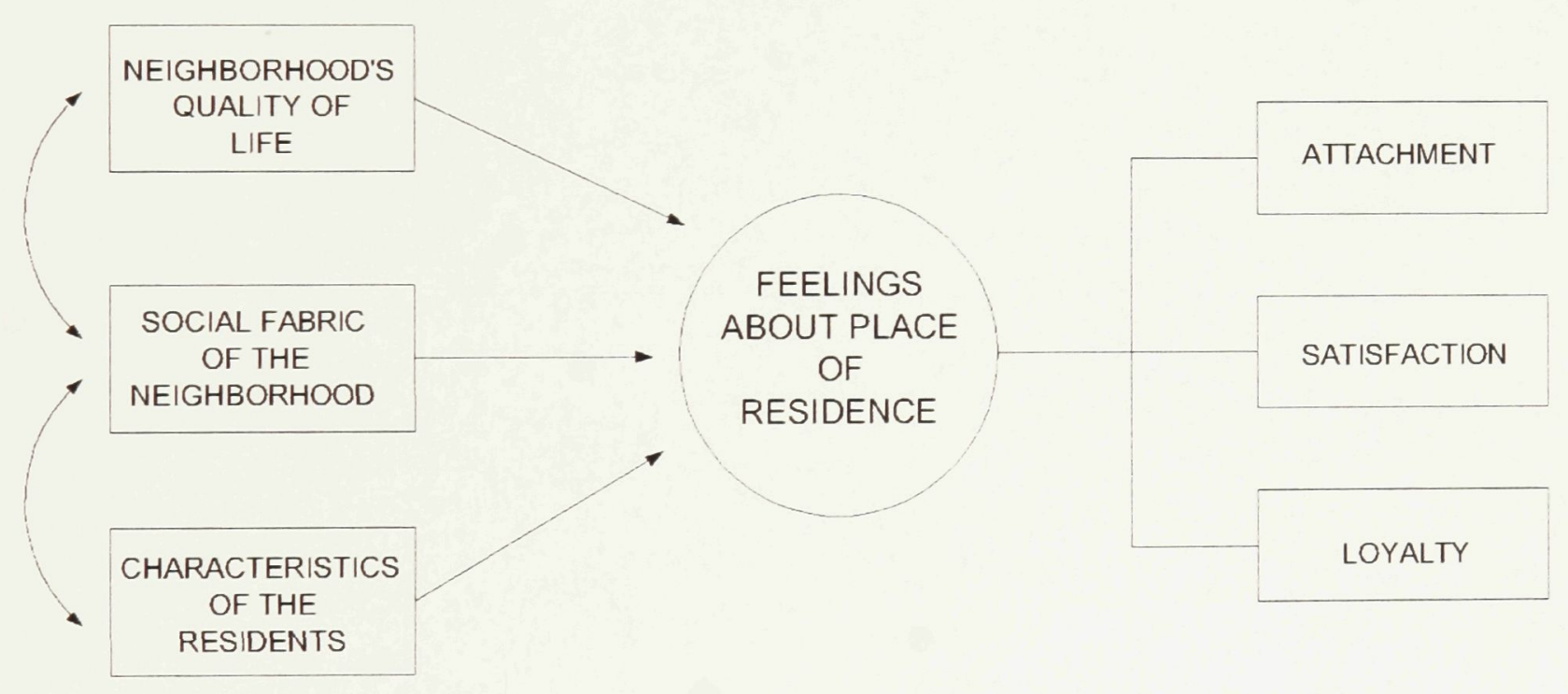

Figure 2.3 Modeling people's feelings about neighbourhood (Ahlbrandt and Cunningham: A New Public Policy for Neighborhood Preservation. 1979) Existing research on neighbourhood and community life raises more questions than it answers, particularly with regard to apartment projects. Furthermore, the variables used in past research are limited in use for different cultural contexts, such as in cities like Guangzhou. 
Previous studies in Hong Kong differ significantly from those of studies carried out in Western countries. For example, high-density living in Hong Kong did not lead to a higher rate of juvenile delinquency and adult crime as in American metropolitan areas (Schmitt, 1963). Moreover, because of sound administration, high-rise residents in Hong Kong have death and disease rates, well below the U. S. rates of the 1960s. Therefore, to study the neighbourhood reality in Guangzhou, careful analysis of what is exactly required. 


\section{CHAPTER III}

\section{RESEARCH METHODOLOGY}

This chapter describes the method of data analysis, the survey questions that were used, and the research methods used to complete the study. The sample population and survey methods, questionnaire, administration procedures, and the results of the pilot survey are also discussed.

\subsection{SYNOPSIS OF SAMPLE AREA--GUANGZHOU}

\subsubsection{Geographic and Climatic conditions}

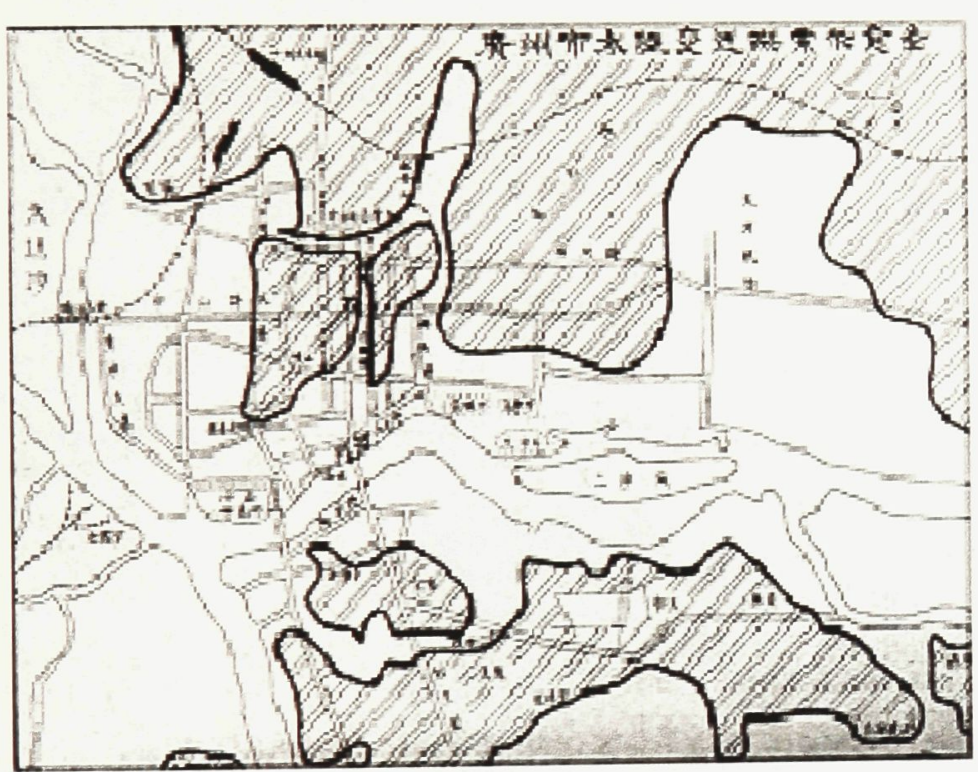

Figure 3.1 Illustration of Ancient Sea Coast Scheme
The first step in sampling is to define the population of interest. Guangzhou, one of the most important cities in South China, is located near the Tropic of Cancer. The history of the city can be traced back to 862 B.C. At that time, it was still a very small coastal village on the shores of the South China Sea and the Pearl River. According to the historical record and archaeological data, the ancient seacoast line position two thousand years ago is as in Figure 3.1. After long time aggradations, the coast line moved $200 \mathrm{~km}$ in a southern direction and a new center of the Pearl River Delta was established. Due to urban development and years of sediment, the Pearl River where it crosses 
Guangzhou has narrowed down to only 200m, from over 500m in Qing Dynasty (1645-1911AD).

Guangzhou enjoys a subtropical, monsoon climate. The Qin Mountains protect the city from the cold and dry winds of northern China. The warm and humid winds from the South China Sea bring much rain and maintain the local temperature at higher than $0^{\circ} \mathrm{C}$ throughout the year. The average temperature is $20-22^{\circ} \mathrm{C}$. Thus, Guangzhou is also named "Hua Cheng", which means "city which flowers in every season". However, the average temperature will rise to average $27.9^{\circ} \mathrm{C}$ during its long summer (from May to September).

\subsubsection{History of Socioeconomic Development}

Early in the Ming Dynasty (1368-1644AD), Guangzhou had developed into one of the major international harbors exporting and importing goods from south Asia and Europe. It is also the beginning of the Sea Silk Road. Before the first opium war (1840), Guangzhou acted as the only

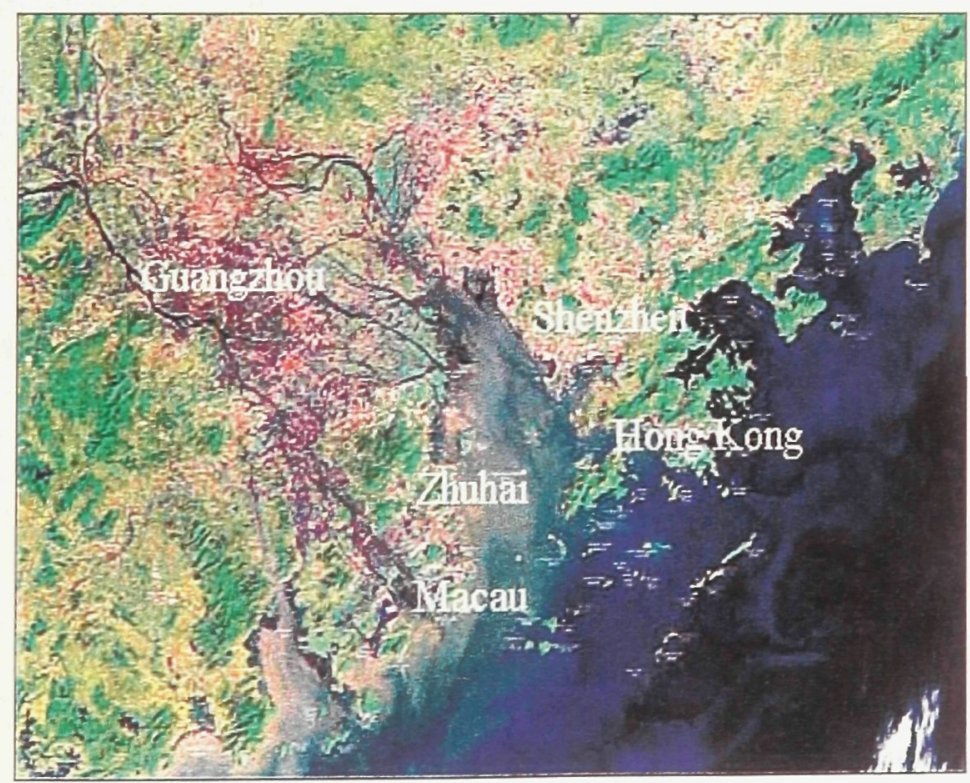

Figure 3.2 The Location of Guangzhou Fosters Economic Growth 
treaty port in China for more than a century. This special position helped Guangzhou develop into an important city over the course of its long history.

After two thousands yeas of progress, Guangzhou not only grew to become the provincial capital of one of the most prosperous provinces in China, but also acted as an important communications and economic hub connecting Southeast Asia with the rest of the world (Figure 3.2). Due to its significant position, the city was designated a centrally administered city when the communist government came to power in October 1949. It later became the capital of Guangdong Province in 1954. In the next pre-reform era, Guangzhou remained a major economic window to the outside world. A famous exhibition, the Chinese Export Commodities Fair, is held there twice a year and it was the only chance for foreign business people to go to China at that time. This became even more important in the early years of economic reform. Because Guangzhou was an important connection between Hong Kong and other special economic zones, such as Shenzhen, Zhuhai and Shantou, it has experienced an explosion in economic and urban development.

Economic reform over the last 20 years has narrowed the economic disparity between Guangzhou and developed nations. In 2003, Guangzhou's GDP had risen to about 350 billion Yuan (approximately 44 billion US\$), about 26 times that of 1978 . The annual income per citizen increased to 15,000 Yuan, about 33 times higher than that of the 1980s. The percentage of income spent on food decreased from $62 \%$ in 1978 to $36.8 \%$ in 2003 , which means that people have more money for other expenditures, such as housing, education, transportation and recreation. Computers, cell phones and other high-tech products have become into the most 
popular commodities in recent years and ownership percentages are close to those of developed countries. Buying automobiles for personal use is also no longer an exceptional circumstance.

\subsubsection{Urbanization}

Before the Economic Reform, the population of Guangzhou was about five million. Between 1978 and 1982, many young people and scholars who had been sent to support the development in the countryside returned to the city. In the following few years, their household members immigrated to the city as well. As a result, the population increased quickly in that period. Over one million people, born in the 1950 s, married and had children in the 1980 s. The birth rate was about $7 \%$ to $10 \%$ annually, but the population increased by $5 \%$ per year during this decade.

Guangzhou's population expansion is a result of migration, as well as an increase in the birth-rate.

The population in Guangzhou has risen to 9.94 million in 2004, about twice than that of 1978 .

Urbanizing rate is greater than $80 \%$ today. The thriving economic climate in the Pearl River Delta continues to attract millions of people from all over the country for the working positions and higher earnings they can achieve. There were 40 millions transients in Guangdong Province and 5 million in Guangzhou. Because of the huge transient population and faulty police system, safety and security are key issues in Guangzhou.

Economic successes in Guangzhou and urbanization have grown in parallel during the last twenty years. The urban area has sprawled from $253.25 \mathrm{~km}^{2}$ to $1,443.6 \mathrm{~km}^{2}$ in 1990 and $3,718.5 \mathrm{~km}^{2}$ in 2000 . Figure 3.3 shows Guangzhou's urban development in the course of the $20^{\text {th }}$ century. The pictures correspond to the downtown area in 1900, 1923, 1954, 1967, 1992 and 
1998. The majority of population is still in the congested urban core. The highest density is more than forty thousand people per $\mathrm{km}^{2}$ in one of the old downtown areas. The average population density is about 1,337 thousand per $\mathrm{km}^{2}$.

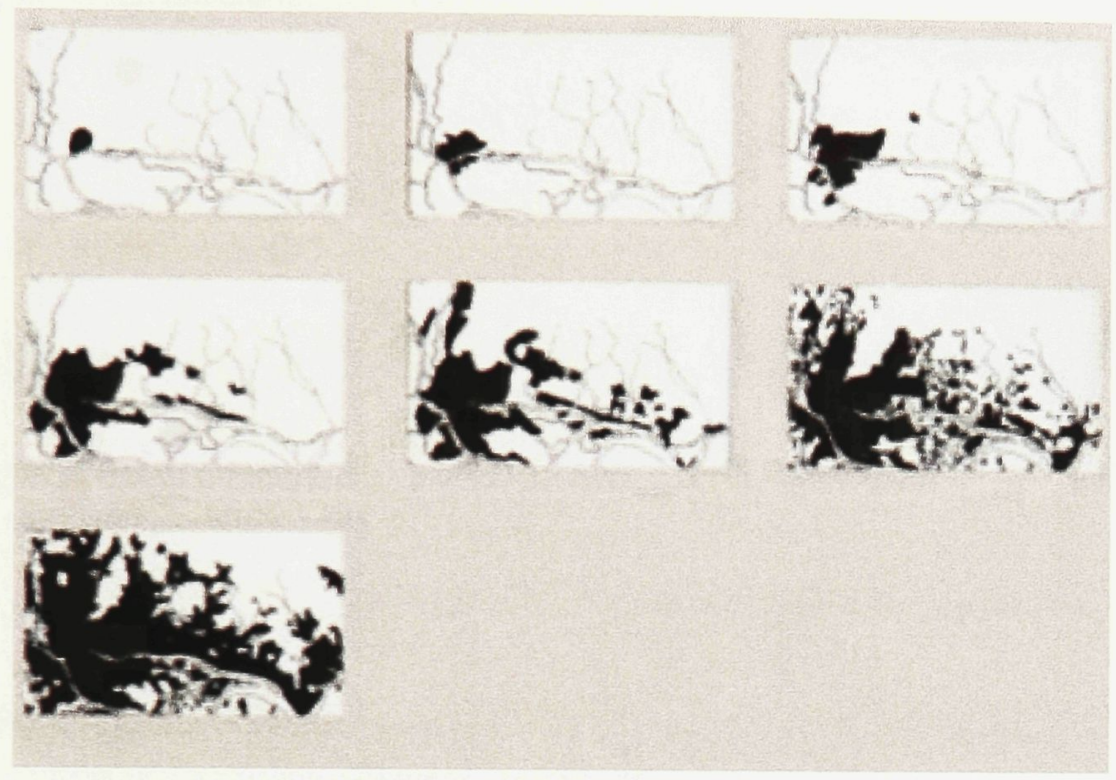

Figure 3.3 Urban Sprawling Processes in Guangzhou (Source: Guangyu, W. 2001, 2)

\subsubsection{Housing Development}

Guangzhou's residential situation has changed tremendously in the last fifty years. The residential area per citizen has increased by a factor of five in two decades, from $3.82 \mathrm{~m}^{2}$ in 1978 to $17.23 \mathrm{~m}^{2}$ in 2003 . The government forecasts that this figure will rise to $20 \mathrm{~m}^{2}$ at the end of this decade. After liberation, housing development in Guangzhou can be divided into three stages:

1) The first period was from 1950 to 1980 , the thirty years after the foundation of the People's Republic of China. At that time, the majority of investment and funding in housing came from the government. After thirty years of civil war, the population doubled from 1.16 million to 4.2 million in this period. However, only limited revenues were used to build 
urban facilities during this period. The budgets for increasing living areas for a rapidly increasing population were even smaller. At this time, people were crowded in traditional houses which were built a half century before, and lacked proper sanitation and were poorly maintained. The residential area per person dropped from $6.4 \mathrm{~m}^{2}$ to $3.82 \mathrm{~m}^{2}$, and most families did not have separate apartments. Residential demand was largely ignored by the communist government.

2) The second stage occurred between 1980 and 1995. Economic reform changed the entire situation in China, allowing both the government and citizens to spend more money to improve their dwellings. The government still had the responsibility for building accommodations for their employees as part of the welfare system. These homes were sold or rented at a price lower than their real value. The funds used for these projects could not, therefore, create a healthy and sustainable cycle. Most of the multi-floor dwellings finished during this era are nine floors without elevators and without any public facilities. Moreover, there was a serious lack of open green space in their residential area. But, the living conditions in these accommodations are still better than those in traditional residences. There were 51.65 million square meters finished in this fifteen year period and the residential area per person increased to $10.7 \mathrm{~m}^{2}$ by 1995 . High-rise housing was still limited by its high construction cost. In 1995, less than thirty percent of housing sold in the real estate market was high-rise.

3) From 1995 to 2004, the living conditions of Guangzhou population improved at an even faster speed. Per-capita housing area increased almost $7 \mathrm{~m}^{2}$ in the decade. At the end of 2001, 
government and state-owned enterprises allowed for the capitalization of housing and its private sale and ownership. Houses owned by the state were sold to their employees at affordable prices. This policy transformation gave a clear message: from now on, everyone who wanted to improve the quality of their residences could do so; solving residential problems was no longer the government's sole responsibility. At the same time, the government created a public mortgage system providing low interest rate loans for people buying their first residences. The concerns of consumers finally became an important guideline for real estate development: more open spaces and green landscapes were built into residential projects; also, if there were insufficient community services, such as shops, schools and sports stadiums, the developer would add them to their projects. There was another important transition during this era. Previous residential development projects got land resources in three ways: urban relocation and reconstruction programs, previous industrial land located in the downtown area and agricultural land. But after ten years of development, the available land resources in the urban core have become scarce. Thus, the residential land price has increased steadily. In order to provide housing at an acceptable price, protect valuable agricultural land and sustain development, the government has encouraged high-rise housing through administrative procedures. High-rise housing represents over $70 \%$ of the housing market from 1998 to 2004 and has quickly become the primary housing option for Guangzhou citizens in recent years.

Traditional low-rise, multi-floor and high-rise housing are three typical typologies in Guangzhou. These housing styles, developed in different historical contexts, express residents' requirements 
in each era. Today, the majority of the population still lives in multi-floor residences. However, the proportion of high-rise living is rising at a high rate. Currently, the floor area in high-rise housing is sold at twice the rate of multi-floor, which means that the percentage of persons living in high-rise apartments will soon exceed that of multi-level units. Guangzhou is presently undergoing a transformation from traditional living styles to a high-rise urban environment, making it an ideal place to survey the population in order to study housing preference.

\subsection{SAMPLING}

Since the objective of this survey is to collect information about contemporary attitudes towards neighbourhood, a random sampling was used to obtain the optimum opportunity of capturing each population group. Based on the approximate population of Guangzhou (nearly 2.37 million households), a sampling of 96 is the minimum requirement to make sure sampling error remains lower than ten percent (50/50 split), with a ninety-five percent confidence level. Increasing the number of responses can reduce sampling error. An actual sample size of 250 was used. We assumed that ninety percent of addresses were correct, that eighty percent of them would respond, and that ninety-nine percent of the questionnaires would be completed. According to these assumptions, at least 180 responses had to be collected in order to yield statistical significance.

\subsection{SURVEY METHOD}

The survey method was used to assess the degree of neighbourhood satisfaction that residents currently experience with respect to various features related to their living conditions. A 
face-to-face survey was chosen for this study because it is generally considered to be the most effective and suitable method for yielding response rates. Interviewers can better arouse the respondent's interest in the study and thereby increase the chance that an individual will participate (Dandekar, 1982). In addition, an interview survey can avoid the problem of an incomplete list. Due to the varied education levels of the population, interview surveys can collect the most accurate data and best understanding for the lengthiest questions. The final survey instrument was made up of 33 closed-ended questions and an open-ended question, divided into four parts: first, the dwelling information of respondents, such as unit area, housing style and length of living; the second part consists of the core survey questions about the present neighbourhood situation and community interests; the third part is about the residents' satisfaction with residential services; the last part gathers the socio-demographic information of the respondents.

\subsection{VARIBALES}

\subsubsection{Dependent Variable}

The dependent variable for this study is the level of overall satisfaction with the neighbourhood.

This evaluation then becomes the foundation for analysis relating it to the independent variables.

Overall satisfaction was assessed by the responses from the survey questionnaire.

\subsubsection{Independent Variables}

Standardized independent variables related to neighbourhood satisfaction can be grouped into 
four main areas: 1) physical quality of the housing (four variables); 2) neighbourhood description (seven variables); 3) overall residential evaluation (four variables); and 4)

socio-economic-demographic data (five variables).

Table 3.1 Description of Neighbourhood Satisfaction Variables used in the Analysis

\begin{tabular}{|c|c|c|c|}
\hline $\begin{array}{c}\text { Variable } \\
\text { Names }\end{array}$ & Variable Description & Question & Remarks * \\
\hline NS & Neighbourhood Satisfaction & 20 & DV \\
\hline PART I & Physical Quality of Housing & & \\
\hline $\mathrm{P} 1$ & Length of Tenure & 1 & IV \\
\hline $\mathrm{P} 2$ & Construction Time & 2 & IV \\
\hline P3 & Unit Size & 5 & IV \\
\hline $\mathrm{P} 4$ & Type of Ownership & 6 & IV \\
\hline PART II & Neighbourhood Description & & \\
\hline N1 & Same Floor Neighbours & 7 & IV \\
\hline N2 & Same building Neighbours & 8 & IV \\
\hline N3 & Willingness to know neighbours & 9 & IV \\
\hline N4 & Safety and Security & 11 & IV \\
\hline N5 & Annoyance and Nuisances & 12 & IV \\
\hline N6 & Participation in Neighbourhood Activities & 15 & IV \\
\hline N7 & Neighbourhood Comparison & 19 & IV \\
\hline PART III & Overall Residential Evaluation & & \\
\hline $\mathrm{O} 1$ & Environmental Satisfaction & 24 & IV \\
\hline $\mathrm{O} 2$ & Dissatisfied Issues & 25 & IV \\
\hline $\mathrm{O} 3$ & Residential Area Selection & 26 & IV \\
\hline $\mathrm{O} 4$ & Elevator Service & 27 & IV \\
\hline PART IV & Socio-economic-demographic Data & & \\
\hline GE & Gender & 30 & IV \\
\hline $\mathrm{AG}$ & Age & 31 & IV \\
\hline EL & Education Level & 32 & IV \\
\hline $\mathrm{HI}$ & Household Income & 33 & IV \\
\hline FP & Family Composition & 34 & IV \\
\hline
\end{tabular}

* DV indicates dependent variable and IV refers to Independent Variable 
As a result, these four areas consist of twenty independent variables that are intended to reflect the residents' perceptions of their neighbourhood reality. Table 3.1 lists all of the variables used in statistical analysis.

\subsection{VALIDITY AND RELIABILITY}

Cook and Campbell (1979) mentioned that it is necessary to invoke the issue of validity geared to reduce the number of plausible alternative interpretations of the data. As Weisberg and Bowen (1996) also emphasize, a useful survey question must be reliable, which means that people should answer it the same way each time they are asked. A good questionnaire reduces the possibility of personal reinterpretations of the data. The validity of a survey question can be checked in several different ways: (1) face validity measures the appropriate concept on its face; (2) convergent validity and divergent validity study the divergent rate of the survey results; (3) criterion validity compares people's answers with a direct measure of the concept of interest; (4) content validity focuses on the complicated aspects of the same concept; (5) construct validity evaluates a measure by how well the measure conforms with theoretical expectations. In dealing with the validity of an interview survey as the main research method, critical issues include coverage errors, sampling errors, measurement errors or bias, and non-response errors.

\subsubsection{Coverage Errors}

A coverage error occurs when the list — or frame — from which a sample is drawn does not include all the elements of the population that researchers wish to study. A sampling survey can 
provide information about the population that makes up the frame and no more. Therefore, it is an elementary questions as to whether the survey has covered the population we want to study in the research, especially in large population. In this study, the sample size used was twice the minimal requirement in order to increase the reliability of the results. Samples were randomly selected from different regions of Guangzhou, regardless of the education, income, age and occupation of the respondent. As a result, reliable generalizations can be made for the average population.

\subsubsection{Sampling Errors}

As a fact of life for those who conduct sample surreys, sampling errors can never be avoided completely. The precision of sample estimates depends very much on the sample size and the size of the sample is a matter of balancing cost and time against the level of precision required. As the sample size increases, the size of the standard error for any estimate does decrease. However, large samples may increase the chance of non-sampling error at the same time. The standard level of statistical significance is 0.05 which is commonly used in this type of researches.

\subsubsection{Measurement Errors or Bias}

Like the sampling error, the occurrence of measurement errors is unavoidable. People tend to have their own interpretation of the questions in a questionnaire. A gap always exists between the respondent's answer to a particular question and the "correct" answer. Measurement errors 
originate from four sources: the survey method, the questionnaire, the interviewer, and the respondent:

1) Survey method error. The selection of survey methods can change the final results of the survey. This research asks respondents for their evaluation of their neighbourhood environments in the form of an interview. The advantage of an interview survey is that it can include complex questions that would be difficult for respondents to answer over the phone or through the mail. A trained interviewer can help the respondent correctly understand what the meaning of a question is. Well designed questions can also minimize unnecessary interpretations, due to the presence of interviewer.

2) Respondent error. Respondents can deliberately or inadvertently answer incorrectly, thus increasing measurement error. Since this survey addresses complicated social issues, the questionnaire uses simple, concise statements, and avoids the use of professional jargon in order to obtain clear results.

3) Questionnaire errors. These occur because the answer choices are not clearly defined. As well, words are not always understood in the same way by all respondents. Using a face-to-face survey can reduced the possibilities of these errors to some extent. Moreover, this questionnaire employs positively-worded statements and a moderate tone to limit the respondents' guesswork. In addition, literature reviews, and pilot surveys were conducted before the surveys were carried out in Guangzhou in order to minimize errors in advance.

4) Interviewer errors. The manner in which the interviewer states and explains the questionnaires can lead to different results. Even trained interviewers have a chance to 
influence the results, through the use of positive or negative tones. Through a training session, the interviewers have an opportunity to participate in the interview, both as a respondent and as an interviewer. This practical program can increase the experience of interviewer and enhance the reliability of the survey.

\subsubsection{Non-response error}

The major source of survey error comes from the often sizeable proportion of samples that are lost through non-response, or because data are missing (Sapsford and Jupp, 1996). Non-response can create two main problems: an unacceptable reduction of sample size and bias. There are two ways to reduce the effects of this problem: first, through careful training of interviewers; second, by drawing an initial sample larger than needed. Through these methods, the non-response rate decreases by about $20 \%$.

\subsubsection{Reliability}

The best methods, however, only apply to measuring the reliability of scales where we have a set of questions to measure one concept rather than single item indicators (Vaus, 1985). This survey studies an abstract or personal concept of neighbourhood and people may understand the questions differently on different occasions. To obtain a higher reliability, multiple-item indicators were introduced into the survey. 


\subsection{PILOT STUDY}

In order to ensure the appropriateness of the survey and its procedure, it was pilot-tested during October of 2004. Twenty people were selected from China and Canada, including some potential interviewers. The response rate increased to $80 \%$ after an additional interview. Ninety percent of the response was usable, which means that all the questions in the questionnaire were finished. The open-ended questions about what is the most satisfying or dissatisfying of their residence were replaced by some closed-end selections. This replacement not only increased the validity of the survey, but also saved time during interviews. The questions about the details of the dwelling unit and its ownership were also added to the questionnaire.

\subsection{QUESTIONNAIRE ADMINISTRATION PROCEDURES AND DATA COLLECTION}

The survey was designed in accordance with the requirements for a Master's thesis in consultation with the thesis advisor. The survey was approved and suggestions for improvement were made. After adjustments, the survey was pilot-tested with the approval of the thesis advisor in October of 2004. Another revision was made after the pilot test and the final edition was completed at the November 2004.

The survey was immediately carried out in Guangzhou in late 2004. The volunteer interviewers were first trained to be non-directive and non-judgmental in administering an interview, especially in dealing with queries raised by the respondent. After two days of training, they were randomly sent out to find residences and started knocking on doors around Guangzhou. 
By the end of November 2004, the interviewer successfully collected about 180 usable surveys from the 250 estimated responses, a response rate of approximately $80 \%$. The survey results were then mailed to Canada for data entry and analysis. 


\section{CHAPTER IV}

\section{DATA ANALYSIS AND RESULTS}

In this chapter the results of the statistical analysis of data and hypothesis testing procedures are presented.

\subsection{DESCRIPTION OF THE SURVEY RESPONDENTS AND HOUSING RELATED CHARACTERISTICS}

\subsubsection{Living Environments}

Respondents can be separated into three groups according to housing style. Over twenty-four percent of the respondents $(n=44)$ live in low-rise dwellings, such as villas, traditional low-rise residences, and low-rise multi-apartment buildings. $50 \%$ of the respondents $(n=90)$ live in multi-floor, mid-rise housing, whereas high-rise residents comprise $25 \%(\mathrm{n}=46)$. These figures are representative of housing in the Guangzhou zone.

Over $87 \%$ of respondents $(n=157)$ own the property they live in, which means only twenty-three households rent the housing. Because rents are higher in high-rise than in multi-floor apartments, $61 \%$ of respondents $(n=14)$ chose to rent multi-floor units, while only two respondents rented a high-rise apartment. $28.3 \%$ of the respondents ( $=51)$ have been living in their current apartments for less than three years; $32.7 \%$ of respondents have lived in their apartments for over ten years. The average length of tenure is approximately seven years, which is much higher than the results found in North America. However, the length of dwelling time that respondents have lived in high-rise buildings is less than four years, compared with the 
tenures of those living in multi-floor housing of almost nine and a half years. Table 4.1 shows the information concerning housing characteristics and the tenure of respondents.

Table 4.1 Housing Characteristics and Tenure

Percentage of respondents

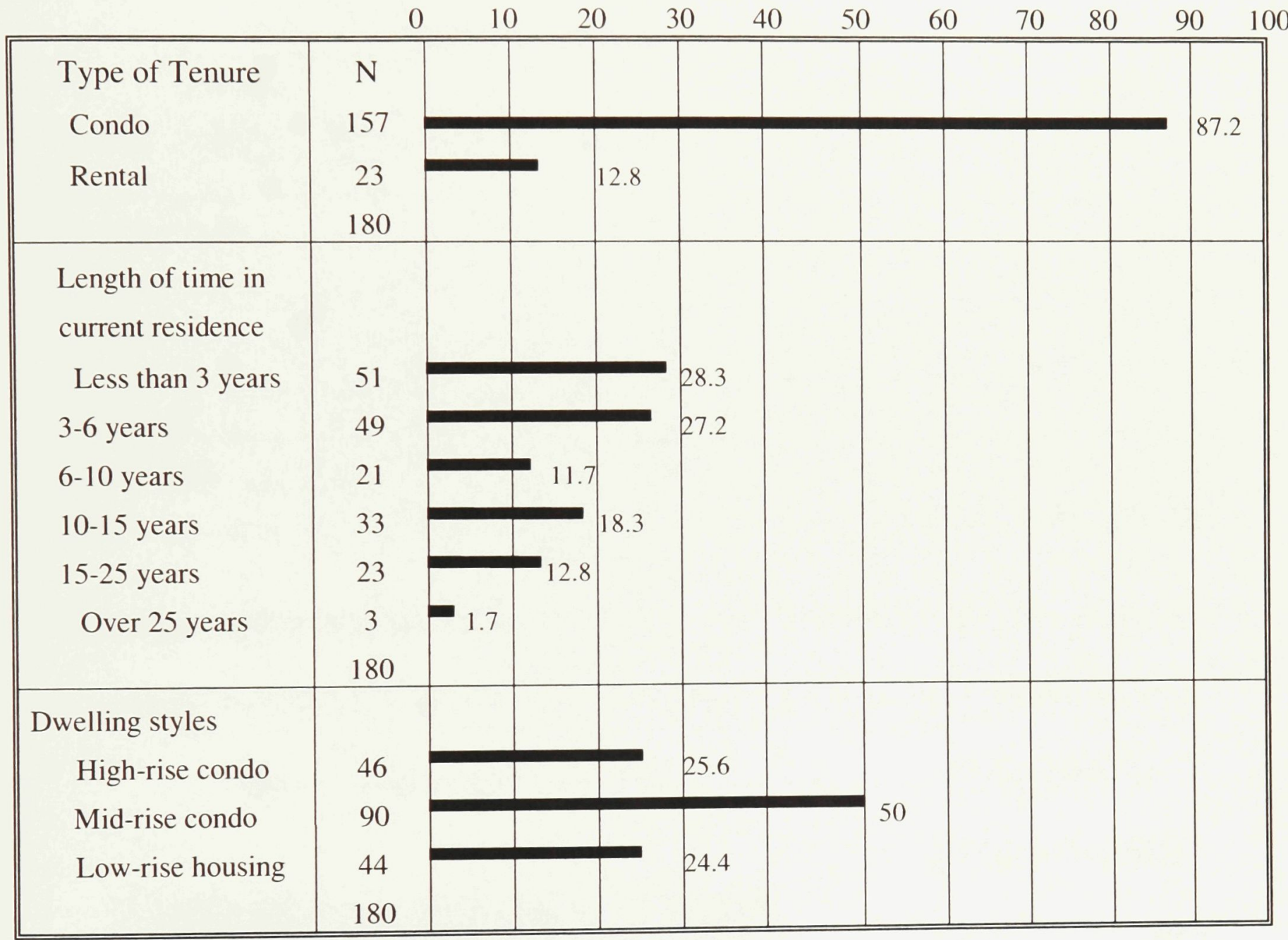

Nearly thirty-three percent of the respondents $(n=59)$ moved into their homes within the past three years, and forty four percent of these $(n=26)$ chose to live in high-rise apartments. The number of people moving into high-rise units for the first time exceeded that for multi-floor apartments. Multi-floor housing is the most popular housing style in the 1990s. Fifty two respondents live in multi-floor housing built from 1980 to 1995 and only two respondents live in housing built within three years. After two decades of urban reconstruction and renewal, most 
traditional residences have been redeveloped in the urban core. $85.6 \%$ of respondents $(n=154)$ dwell in a home completed in the 1990s. This era was a boom time for reconstruction projects that thoroughly destroyed old neighbourhoods.

Table 4.2 Housing Age and Style

\begin{tabular}{|l|c|c|c|c|c|c|c|}
\hline $\begin{array}{r}\text { Housing } \\
\text { Housing }\end{array}$ & \multicolumn{2}{|c|}{$\begin{array}{c}\text { Low-rise } \\
\text { Style }\end{array}$} & Respondents & \multicolumn{2}{c|}{$\begin{array}{c}\text { Multi-storey } \\
\text { Housing }\end{array}$} & \multicolumn{2}{c|}{$\begin{array}{c}\text { High-rise } \\
\text { housing }\end{array}$} \\
\hline Age & & $\#$ & $\%$ & $\#$ & $\%$ & $\#$ & $\%$ \\
\hline less than 3 years & 17 & 1 & $2.3 \%$ & 2 & $2.2 \%$ & 14 & $30.4 \%$ \\
\hline 3-6 years & 44 & 12 & $27.3 \%$ & 13 & $14.4 \%$ & 19 & $41.3 \%$ \\
\hline 6-9 years & 48 & 12 & $27.3 \%$ & 28 & $31.1 \%$ & 8 & $17.4 \%$ \\
\hline $10-15$ years & 39 & 10 & $22.7 \%$ & 25 & $27.8 \%$ & 4 & $8.7 \%$ \\
\hline $15-25$ years & 24 & 4 & $9.1 \%$ & 19 & $21.1 \%$ & 1 & $2.2 \%$ \\
\hline over 25 years & 8 & 5 & $11.4 \%$ & 3 & $3.3 \%$ & 0 & $0.0 \%$ \\
\hline Total & 180 & 44 & $100.0 \%$ & 90 & $100.0 \%$ & 46 & $100.0 \%$ \\
\hline
\end{tabular}

The average dwelling area has increased steadily during the past thirty years. The average size has increased from $65.6 \mathrm{~m}^{2}$ to $85.6 \mathrm{~m}^{2}$ and each residence has an average of 2.5 rooms and

Figure 4.1 Changes of Dwelling Area

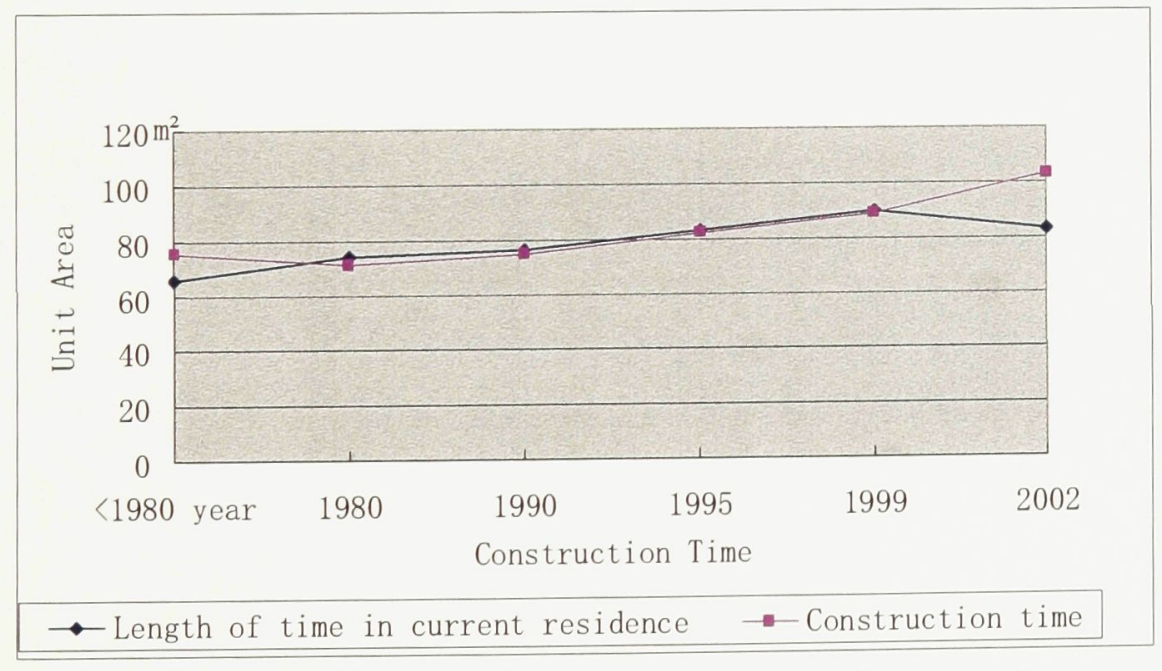

1.2 bathrooms. On

average, every household

member can now have their

own bedroom. Only one

person still lives in a rented

apartment without a bathroom.

Owning a completed

apartment is thus no longer a dream for most people in Guangzhou today (see Figure 4.1). 


\subsubsection{Description of the Respondents}

$55.6 \%$ of respondents were male $(\mathrm{n}=100)$ and 80 female respondents completed the survey. The average age of male respondents was 43.5 years old and female respondent, $45.7 .8 .9 \%$ of respondents were aged seventy or older, whereas $26.7 \%$ respondents were between 55 and 70 .

Twenty-six percent were respondents between the ages of 20 and 29.

Table 4.3 Characteristics of Respondents: Gender, Age and Family Composition

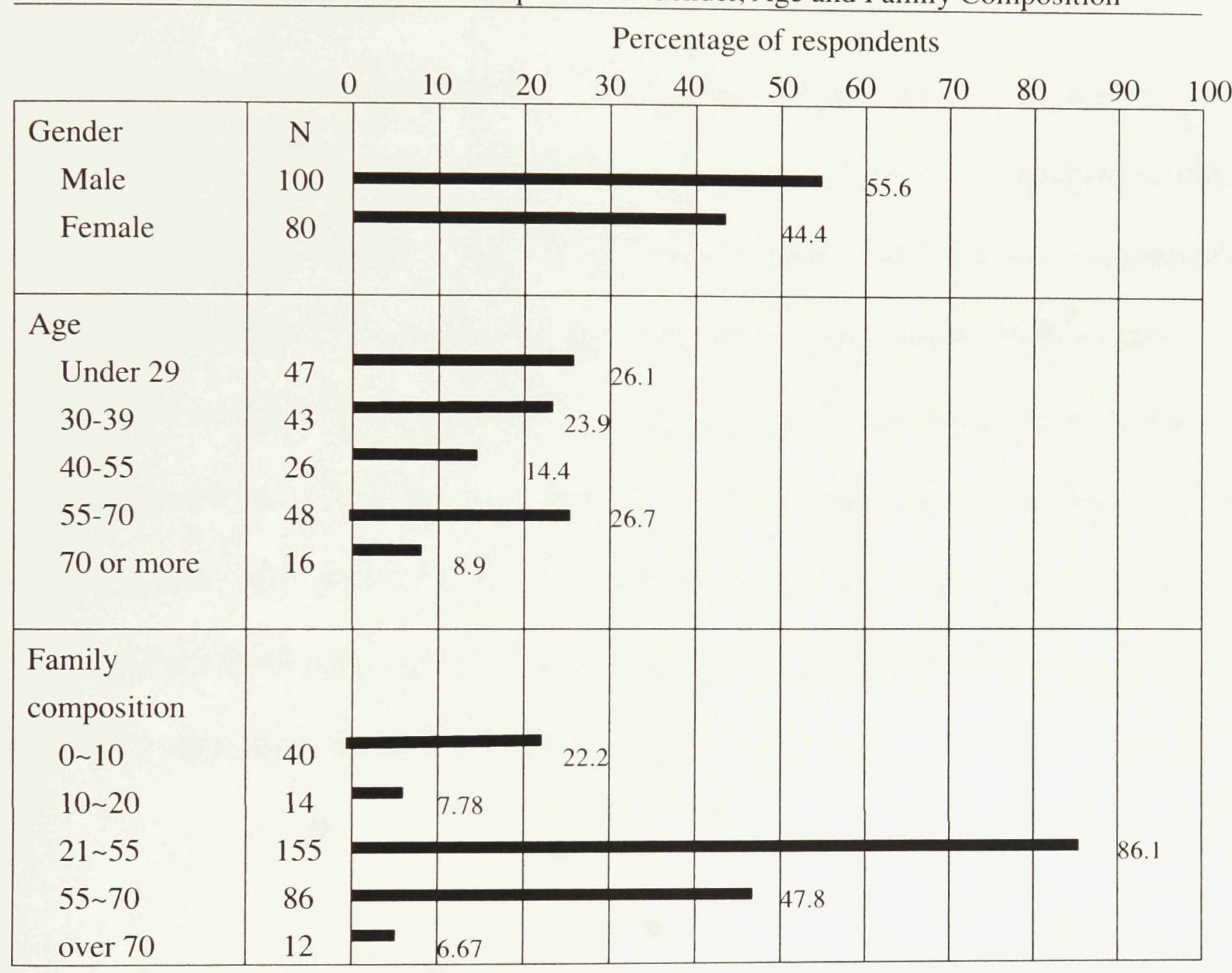

Due to the improvement in economic conditions and family planning in the last two decades, the family size in Guangzhou has dropped from 4.01 in 1980 to 3.21 in 2004 (Popin., 
2004). The survey corroborated this trend, finding an average of 2.82 persons per household. Because of Chinese traditional culture, elder parents will live with their next generation. The survey proves this - over 51.7 percent of those interviewed live with an elder over 55. Forty families, or $22.2 \%$ of respondent households, have children under the age of 10 , and only 14 families (7.8\%) have children between 11 and 20. Table 4.3 indicates the characteristics of the respondents for gender, age and family composition.

Over $69.4 \%$ of the respondents $(n=125)$ have some college education, but only $3.3 \%$ holding a Master's degree or more $(n=6)$. The majority of the respondents, 66.7 percent $(n=120)$, indicated that they were employed on a full-time basis, whereas $33.6 \%$ of the survey respondents were not employed or were retired. The respondents include many professionals and trades people, such as teachers, government officers, high-tech engineers, architects, and so on. The median annual household income bracket was from $\$ 3600$ to $\$ 7200$ in this survey. Twenty-seven percent of respondents indicated annual household income of $\$ 7200$ or more, but there were still $32.2 \%$ of respondents with an annual household income of less than $\$ 3600$. Table 4.4 shows the education, employment and income characteristics of the respondents. 
Table 4.4 Characteristics of Respondents: Education, Employment and Household Income

\begin{tabular}{|c|c|c|c|c|c|c|c|c|c|c|c|}
\hline \multirow{2}{*}{\multicolumn{2}{|c|}{(}} & \multicolumn{10}{|c|}{ Percentage of respondents } \\
\hline & & 10 & & 20 & 40 & 50 & 60 & 70 & 80 & 90 & 100 \\
\hline Education & $\mathrm{N}$ & & & & & & & & & & \\
\hline Public School & 19 & & 10.6 & & & & & & & & \\
\hline High School & 36 & & & 20 & & & & & & & \\
\hline College & 47 & & & & 26.1 & & & & & & \\
\hline University & 72 & & & & & 40 & & & & & \\
\hline Post Graduate & 6 & 3.3 & & & & & & & & & \\
\hline Employment & & & & & & & & & & & \\
\hline Employed full time & 120 & & & & & & & & 66.7 & & \\
\hline Not employed & 18 & & & 10 & & & & & & & \\
\hline Retired & 42 & & & & 23.3 & & & & & & \\
\hline Household income & & & & & & & & & & & \\
\hline Under $\$ 3600$ & 58 & & & & 32.2 & & & & & & \\
\hline$\$ 3,600-7,200$ & 73 & & & & & 40.6 & & & & & \\
\hline$\$ 7,200-10,800$ & 31 & & & 17.2 & & & & & & & \\
\hline$\$ 10,800-21,600$ & 17 & & 9.4 & & & & & & & & \\
\hline$\$ 21,600-54,200$ & 1 & 0.6 & & & & & & & & & \\
\hline$\$ 54,200$ or more & & & & & & & & & & & \\
\hline
\end{tabular}

\subsection{DISCUSSION OF RESULTS}

\subsubsection{Physical Quality of Housing and Neighbourhood Satisfaction}

\section{Housing Style and Neighbourhood}

In the low-rise housing group $(\mathrm{n}=44)$, twenty-three respondents $(52.3 \%)$ indicated that they were satisfied with their housing. This percentage decreased to $41 \%$ among multi-storey residents.

However, twenty-nine respondents (over 64\%) who were high-rise dwellers were satisfied with their neighbourhood environment. No one was completely unsatisfied among the high-rise residents, whereas 4 people living in multi-floor dwellings and two in low-rises were unsatisfied 
with their neighbourhoods, as shown in Table 4.5.

Table 4.5 Neighbourhood Satisfaction and Dwelling style

\begin{tabular}{|c|c|c|c|c|c|c|}
\hline \multirow{2}{*}{ Deighelling Style } & \multicolumn{2}{|c|}{ Low-rise } & \multicolumn{2}{c|}{ Multi-floor } & \multicolumn{2}{c|}{ High-rise } \\
\cline { 2 - 7 } & $\mathrm{N}$ & $\%$ & $\mathrm{~N}$ & $\%$ & $\mathrm{~N}$ & $\%$ \\
\hline Satisfied & 23 & 52.3 & 37 & 41.1 & 29 & 64.4 \\
\hline Normal & 19 & 43.2 & 48 & 53.3 & 17 & 35.6 \\
\hline Unsatisfied & 2 & 4.5 & 5 & 5.6 & 0 & 0 \\
\hline Total & 44 & 100 & 90 & 100 & 46 & 100 \\
\hline
\end{tabular}

\section{Tenure and Neighbourhood}

Tenants living in multi-floor buildings seem to be the most unsatisfied with their neighbourhood environment. Only $20 \%$ of residents $(n=3)$ in multi-floor dwellings are satisfied with their neighbourhoods, compared with $66.7 \%$ in low-rises and $100 \%$ in high-rises. More renters like their neighbours in low-rise buildings than in any other housing types. It appears that it is easier to integrate smoothly into the existing community in low-rise dwellings (see Table 4.6).

Table 4.6 Tenure and Neighbourhood Satisfaction by Dwelling Style

\begin{tabular}{|c|c|c|c|c|c|c|}
\hline \multirow{2}{*}{ Tenure } & \multicolumn{2}{|c|}{ Low-rise } & \multicolumn{2}{c|}{ Multi-floor } & \multicolumn{2}{c|}{ High-rise } \\
\cline { 2 - 7 } Neighbourhood & own & rent & own & rent & own & rent \\
\hline Satisfied & 19 & 4 & 34 & 3 & 27 & 2 \\
\hline Neutral & 17 & 2 & 38 & 10 & 17 & 0 \\
\hline Unsatisfied & 2 & 0 & 3 & 2 & 0 & 0 \\
\hline Total & 38 & 6 & 75 & 15 & 44 & 2 \\
\hline
\end{tabular}

\subsubsection{Neighbourhood Description and Neighbourhood Satisfaction}

\section{Neighbour Quantity}

In the second part of the questionnaire, two design-related questions were included. The first question asks how many neighbours the respondents knew on the same floor where he (or she) 
lives. The next question asked for the number of the neighbours that the respondent was familiar with in the same building. The objective of these two questions is to study the relation between the number of known neighbours and neighbourhood satisfaction. In multi-storey housing, over $52 \%(n=47)$ of respondents know all their neighbours on the same floor, whereas only $20 \%$ of high-rise residents are familiar with all their same-floor neighbours. Other than the neighbours living on the same floor, high-rise respondents only familiarized an average of five neighbours living in their building, while multi-floor dwellers knew about 8 neighbours. However, the number of dwelling units in high-rise buildings is at least twice that of multi-floor buildings. Approximately nine percent of respondents living in high-rise did not know any neighbours. This figure is much higher than people in multi-floor or low-rise residences, which were just five percent and two percent respectively. A survey done in Guangzhou 1994 demonstrated an average of $4.5 \%$ of people (1,000 respondents) knew nothing about their neighbours (Feng, 2003). These results suggest that the current design of high-rise buildings do not provide enough chances for residents to interact with each other (see Table 4.7). 15\% of respondents living in high-rises were unwilling to know their neighbours. Their reasons included "too busy", "do not have good opportunities" and "do not have attractive community activities". Knowing more neighbours can increase place identity, which could also decrease vacancies, rent arrears and a high churn rate. There are important issues in determining the financial feasibility of high-rise housing projects. 
Table 4.7 Number of Known Neighbours

\begin{tabular}{|l|c|c|c|}
\hline \multicolumn{1}{|c|}{ Dwelling Styles } & Low-rise & Multi-storey & High-rise \\
\hline Same Floor Neighbours & $2.84^{*}$ & $2.16^{*}$ & $2.96^{*}$ \\
\hline Other Floors & 6.56 & 7.93 & 5.17 \\
\hline Same Building Neighbours & 9.4 & 10.09 & 8.1 \\
\hline
\end{tabular}

*Average apartments on the same floor: low-rise, 6.13; multi-storey, 4.28; and high-rise, 7.09.

\section{Safety and Security}

Ramirez (1981) found that high-rise condominiums are safer than other forms of dwelling. The survey results show that the Guangzhou residents agree with this. Only four people felt they lived in a place more dangerous than before. Twenty-two respondents in multi-story and eight in low-rises had the same feeling. However, housing security systems require significant amounts of money for facilities and equipment, and then residents must also use a major part of their monthly management fees to pay for a security guard. Besides a security gate, most dwellers will install another iron gate in the front of their house units. Residents now usually rely on a physical security system, and traditional neighbourhood safety has largely been replaced. Women are more safety conscious than men in this survey. Table 4.8 shows that women feel safer in high-rises buildings.

Table 4.8 Gender and Safety in Different Dwelling Styles

\begin{tabular}{|c|c|c|c|c|c|c|}
\hline & \multicolumn{2}{|c|}{ High-rise } & \multicolumn{2}{c|}{ Multi-storey } & \multicolumn{2}{c|}{ Low-rise } \\
\cline { 2 - 7 } & Males & Females & Males & Females & Males & Females \\
\hline Safe & $25(100 \%)$ & $17(81 \%)$ & $34(69 \%)$ & $31(76 \%)$ & $23(88 \%)$ & $13(72 \%)$ \\
\hline Not Safe & 0 & $4(19 \%)$ & $15(31 \%)$ & $10(24 \%)$ & $3(12 \%)$ & $5(28 \%)$ \\
\hline Total & 25 & 21 & 49 & 41 & 26 & 18 \\
\hline
\end{tabular}




\section{Annoyances and Nuisances}

There are six issues listed in the questionnaire: excessive noise, vandalism, graffiti, littering, invasion of public spaces and crime. Excessive noise is the most common annoyance in the respondents' community. Over $71 \%(\mathrm{n}=128)$ of respondents had suffered from this nuisance, no matter what kind of dwellings they live in. This problem seems even more serious in high-rise buildings: twelve percent higher than people living in multi-floor buildings, which received $68 \%$ of respondents' complaints (see Table 4.9).

Table 4.9 Annoyances and Nuisances in Different Dwellings

\begin{tabular}{|l|c|c|c|c|c|c|}
\hline & \multicolumn{2}{|c|}{ Low-rise $(\mathrm{n}=44)$} & \multicolumn{2}{c|}{ Multi-storey(n=90) } & \multicolumn{2}{c|}{ High-rise(n=46) } \\
\cline { 2 - 7 } & $\mathrm{N}$ & $\%$ & $\mathrm{~N}$ & $\%$ & $\mathrm{~N}$ & $\%$ \\
\hline Excessive Noise & 31 & $70.50 \%$ & 61 & $67.80 \%$ & 36 & $78.30 \%$ \\
\hline Vandalism & 9 & $20.50 \%$ & 13 & $14.40 \%$ & 9 & $19.60 \%$ \\
\hline Graffiti & 10 & $22.70 \%$ & 13 & $14.40 \%$ & 10 & $21.70 \%$ \\
\hline Littering & 25 & $56.80 \%$ & 54 & $60 \%$ & 19 & $41.30 \%$ \\
\hline Invading public space & 30 & $68.20 \%$ & 43 & $47.80 \%$ & 11 & $23.90 \%$ \\
\hline Crime & 16 & $36.40 \%$ & 29 & $32.20 \%$ & 10 & $21.70 \%$ \\
\hline
\end{tabular}

In high-rise housing, the management system seems to work well in preventing other behaviors, such as littering and improper occupancy public spaces. Complain about those issues in high-rises were twenty percent lower than in other dwelling styles. These factors affect a person's evaluation of their neighbourhood quality. Good management systems are a definite advantage with respect to dwelling satisfaction (see Table 4.10). 
Table 4.10 Issues and Neighbourhood Satisfaction by Dwelling Styles

\begin{tabular}{|c|c|c|c|c|c|}
\hline & & $<2$ Issues & 3 or 4 Issues & 5 or 6 Issues & Total \\
\hline \multirow{3}{*}{ Low-rise } & Satisfied & 16 & 5 & 2 & 27 \\
\hline & Normal & 6 & 9 & 4 & 19 \\
\hline & Dissatisfied & 1 & 1 & 0 & 2 \\
\hline \multirow{3}{*}{ Multi-storey } & Satisfied & 27 & 9 & 1 & 37 \\
\hline & Normal & 29 & 14 & 5 & 48 \\
\hline & Dissatisfied & 0 & 2 & 3 & 5 \\
\hline \multirow{3}{*}{ High-rise } & Satisfied & 19 & 9 & 1 & 29 \\
\hline & Normal & 12 & 2 & 3 & 17 \\
\hline & Dissatisfied & 0 & 0 & 0 & 0 \\
\hline
\end{tabular}

Low-rise $\chi^{2}=13.29, \mathrm{df}=4, \rho<0.01$; Multi-storey $\chi^{2}=18.76, \mathrm{df}=4, \rho<0.01 ;$ High-rise $\chi^{2}=7.04 \mathrm{df}=2, \rho<0.1$.

\subsubsection{Residential Quality and Neighbourhood Satisfaction}

In the third part of the questionnaire, respondents were asked another pair of related questions about satisfying or dissatisfying items in their residential area. Public transit, shopping and community safety were the first three priorities for respondents (see Table 4.11). Most respondents were not pleased with the neighbourhood relationship in their community. Only twenty-three percent ( $\mathrm{n}=52$ ) of citizens chose "good neighbourhood" in the survey. People living in low-rise gave the highest mark to this issue: over $43 \%(n=19)$ prized their neighbourhood, compared to $21 \%$ in multi-storey and $27 \%$ in high-rises structures.

On the other hand, when people were asked about the shortcomings in their living environments, lack of recreation facilities, lack of open space and green space represented the majority of their concerns. Those deficiencies may be a consequence of living in the urban core for people around the world. According to the survey, people living in high-rises were more 
satisfied with their dwelling quality other than dwelling style. Most high-rise units were finished in the past ten years and developers invested more money in these facilities to cope with consumers' concerns about their quality of life. Fewer people living in high-rises wanted to move to suburbia than other dwelling styles: only $41 \%$ wanted to change their living environment, whereas $68.2 \%$ residents in low-rise units and $53.3 \%$ in multi-storey dwellings wanted to relocate to the suburbs.

Table 4.11 Dwelling Factors and Different Housing Style

\begin{tabular}{|l|c|c|c|c|c|c|}
\hline & \multicolumn{2}{|c|}{ Low-rise (n=44) } & \multicolumn{2}{c|}{ Multi-storey(n=90) } & \multicolumn{2}{c|}{ High-rise (n=46) } \\
\cline { 2 - 7 } & $\mathrm{N}$ & $\%$ & $\mathrm{~N}$ & $\%$ & $\mathrm{~N}$ & $\%$ \\
\hline Convenient Shopping & 28 & $63.6 \%$ & 49 & $54.4 \%$ & 21 & $45.65 \%$ \\
\hline Good Neighbourhood & 19 & $43.2 \%$ & 21 & $23.3 \%$ & 12 & $26.09 \%$ \\
\hline Housing Design & 13 & $29.5 \%$ & 30 & $33.3 \%$ & 13 & $28.26 \%$ \\
\hline Community Security & 18 & $40.9 \%$ & 33 & $36.7 \%$ & 28 & $60.87 \%$ \\
\hline Public Traffic & 33 & $75.0 \%$ & 53 & $58.9 \%$ & 26 & $56.52 \%$ \\
\hline Education Facilities & 7 & $15.9 \%$ & 14 & $15.6 \%$ & 13 & $28.26 \%$ \\
\hline Recreation Facilities & 6 & $13.6 \%$ & 13 & $14.4 \%$ & 6 & $13.04 \%$ \\
\hline Social Relationship & 7 & $15.9 \%$ & 10 & $11.1 \%$ & 3 & $6.52 \%$ \\
\hline Open and Green Space & 12 & $27.3 \%$ & 19 & $21.1 \%$ & 10 & $21.74 \%$ \\
\hline Quiet Environment & 11 & $25.0 \%$ & 32 & $35.6 \%$ & 13 & $28.26 \%$ \\
\hline Housing Management & 7 & $15.9 \%$ & 19 & $21.1 \%$ & 20 & $43.48 \%$ \\
\hline View & 4 & $9.1 \%$ & 15 & $16.7 \%$ & 7 & $15.22 \%$ \\
\hline
\end{tabular}

\subsubsection{Respondent Characteristic and Neighbourhood Satisfaction}

The neighbourhood satisfaction level of people who have university education is significantly $20 \%$ lower than other respondents. Education broadens a person's horizon and increases their expectation. Therefore, the criteria used to determine neighbourhood satisfaction are much 
higher for people who have more education.

From the survey, women are 15\% more satisfied with their neighbourhood than men.

Whyte (1984) found that Chinese women do the bulk of household chores, such as shopping, laundry and cooking, even though they may work full-time jobs. This 'double burden' gives women more opportunity to create social interaction with their neighbours. Women know more of their neighbours and seem to more easily to integrate into community than men. Therefore, it is not surprising that they are more satisfied with their neighbourhoods.

\subsection{The NEIGHBOURHOOD SATISFACTION MODEL IN GUANGZHOU}

The relationship between neighbourhood satisfaction and the independent variables is shown in Figure 3.4. Multivariate statistical techniques were used to study these relationships. The basic model used for analytical purposes is shown in Equation 1:

$$
\text { (1) } \mathrm{S}=\mathrm{a}_{0}+\mathrm{a}_{1} \mathrm{P}+\mathrm{a}_{2} \mathrm{~N}+\mathrm{a}_{3} \mathrm{O}+\mathrm{a}_{4} \mathrm{SE}+\mathrm{e}
$$

where $\mathrm{S}$ = neighbourhood satisfaction (low-rise, multi-floor, high-rise); $\mathrm{a}_{0}=$ constant term; $\mathrm{a}_{1}-\mathrm{a}_{4}$ $=$ coefficients; $\mathrm{P}=$ physical quality of housing; $\mathrm{N}=$ neighbourhood description; $\mathrm{O}=$ overall residential evaluation; $\mathrm{SE}=$ socio-economic-demographic data; and e $=$ error term. Although theoretically there could be potential interaction effects between the independent variables, the correlations between the variables are not high enough. The correlation matrix for all of the variables used in the analysis is shown in Appendices E, F, G.

The results of multiple regression analysis are shown in Table 4.12. The coefficients are different for different housing styles. With respect to satisfaction for high-rise neighbourhoods, 
the primary explanatory variable (positively related), is their satisfaction with their vertical transportation - their elevator. The age variable is not an important explanatory variable for

Table 4.12 Neighborhood Satisfaction: Stepwise Multiple Regression Analysis

\begin{tabular}{|c|c|c|c|}
\hline \multirow[b]{2}{*}{ Independent Variables } & \multicolumn{3}{|c|}{ Neighbourhood Satisfaction } \\
\hline & Low-rise & Multi-storey & High-rise \\
\hline \multicolumn{4}{|l|}{ Physical Quality of Housing } \\
\hline Length of Tenure & $-0.04[17]$ & $0.02[16]$ & $-0.17[10]$ \\
\hline Construction Time & $0.24[10]$ & $-0.06[11]$ & $-[18]$ \\
\hline Unit Size & $0.54[3]$ & $-0.16[7]$ & $0.3[3]$ \\
\hline Type of Ownership & $-0.21[12]$ & $0.21[3]$ & $0.29[4]$ \\
\hline \multicolumn{4}{|l|}{ Neighbourhood Description } \\
\hline Same Floor Neighbours & $0.25[9]$ & $0.09[9]$ & $-0.14[11]$ \\
\hline Same building Neighbours & $0.56[2]$ & $0.08[10]$ & $-0.23[7]$ \\
\hline Willingness to know neighbours & $-[19]$ & $0.02[15]$ & $-[19]$ \\
\hline Safety and Security & $0.22[11]$ & 0.24 [2] & $0.08[15]$ \\
\hline Annoyance and Nuisances & $-0.47[4]$ & $0.03[14]$ & $0.18[9]$ \\
\hline Participation in Neighbourhood Activities & $-0.27[8]$ & $-[17]$ & $-0.02[17]$ \\
\hline Neighbourhood Comparison & $-0.28[7]$ & $0.03[13]$ & $0.04[16]$ \\
\hline \multicolumn{4}{|l|}{ Overall Residential Evaluation } \\
\hline Environmental Satisfaction & $0.64[1]$ & $-0.04[12]$ & $0.11[12]$ \\
\hline Dissatisfied Issues & $0.29[6]$ & $-[18]$ & $-0.11[13]$ \\
\hline Residential Area Selection & $-0.16[15]$ & $0.11[8]$ & $-0.11[14]$ \\
\hline Elevator Service & $-[20]$ & $-[19]]$ & $-0.37[1]$ \\
\hline \multicolumn{4}{|l|}{ Socio-economic-demographic Data } \\
\hline Gender & $-[18]$ & $-[20]$ & $-0.26[6]$ \\
\hline Age & $0.19[13]$ & $0.26[1]$ & $-0.35[2]$ \\
\hline Education Level & $0.13[16]$ & $0.17[4]$ & $0.21[8]$ \\
\hline Household Income & $-0.35[5]$ & $0.17[5]$ & $-0.29[5]$ \\
\hline Family Composition & $0.17[14]$ & $0.16[6]$ & $-[20]$ \\
\hline $\mathrm{N}$ & 44 & 90 & 46 \\
\hline $\mathrm{R}^{2}$ & 0.15 & -0.02 & 0.18 \\
\hline
\end{tabular}


low-rise residents, but it is for high-rise and mid-rise. The area of residence and tenure are important variables for both multi-storey and high-rise residents' evaluation of their neighbourhoods. It is interesting to note that household income has the same importance for each kind of residence.

\subsection{COMMUNITY INTERESTS}

Michelson (1974) described the high-rise neighbourhood as different from traditional neighbourhoods for other types of dwellings. They formed communities of interest based on factors other than location. Women living in high-rise apartments by and large meet even their local friends through communities of interests rather than through territorially based neighbourhoods. Understanding what and where residents' interests are can greatly help the designer in establishing immediate neighbourhoods in high-rises. The survey sought out information about communal interests in Guangzhou.

Nearly half of all respondents feel that they have little chance to take part in community activities. However, there is a polarization in the high-rise figures. The number of people $(n=18)$ feeling they attended more activities is almost the same as people who do not feel that way $(n=20)$. The average number of activities they had signed up for proving this difference: residents who participated more in the community had a higher housing satisfaction. Of the six activities, shopping, social entertainment and festival celebrations were the most popular activities among the high-rise residents. Over $65 \%$ of inhabitants attend less than one activity in each time period. However, only one respondent refused to take part in these kinds of activities; eleven 
respondents were eager to attend. More young men are interested in these activities than women.

When the interviewer asked respondents why they did not wish to be present at such activities, most people used an excuse such as 'no time' or 'too busy'. Few people do not want to attend neighbourhood activities. People will go to these activities if they have a well-planned schedule.

To enhance the neighbourhood design in high-rise housing, residents' common interests should be studied before attempting a design. In question 17 , a respondent was required to use 1-10 to gauge their interest in certain activities (where 10 means high interest and 1 means no interest at all). Activities included sports, exercise, fashion, shopping, cooking, eating, etc. From the survey, contemporary Guangzhou residents were most interested in sports and exercise. This result explained why so many people complain about the insufficient amount of open space and sports facilities in the previous question. According to this, open spaces and sport facilities should be a priority activity in new community design. Fitness rooms and small gardens can double as small neighbourhood centers acting as local shops and bars in the formal street environment.

Guangzhou is also famous for its delicious cuisine. The cooking culture has a very long history in Guangzhou. In ancient times, Chinese scholars chose four best places to represent the important moments in the human life cycle: birth, eating, living and death. Guangzhou was described as the first choice where one could find the most delicious foods in China. People living in Guangzhou have a strong fascination with eating and cooking-this is confirmed in the survey results. Eating and cooking were third and fourth place on the interest list. As a result, community design could provide locations and communal kitchen appliances for cooking 
courses and shared cooking experiences. An activity involving cooking will attract more people than any other joint activity. 


\section{Chapter V}

\section{Concept Design: High-rise Residential Housing for Guangzhou}

What type of high-rise residential building in downtown Guangzhou will result from this research? What building improvements will enhance "neighbourhood" effects in high-rise housing? To answer these questions, we need to focus on local culture and the needs of residents.

Based on our multi-variable analysis of neighbourhood satisfaction in Guangzhou, we have developed a conceptual design for a new high-rise type of dwelling. The architectural expression in this design seeks to counteract the isolation commonly felt in urban communities. Typically, a design for a high-rise dwelling must accommodate both resident and economic concerns. However, many contemporary high-rise designs have focused on profit, and often lack a consideration for the human element.

After twenty years of development, the physical living quality of new high-rise dwellings in Guangzhou has slowly caught up with those of developed nations. When people choose a place to create a new home, location is no longer the primary factor. The quality of the neighbourhood is increasingly being identified by more and more urbanites as the most important factor. As an old Chinese saying goes, “spending ten thousand on a good neighbourhood is better than spending one thousand on your house." Therefore, our design concept attempts to introduce neighbourhood elements into contemporary Chinese design themes. 


\subsection{Project Site}
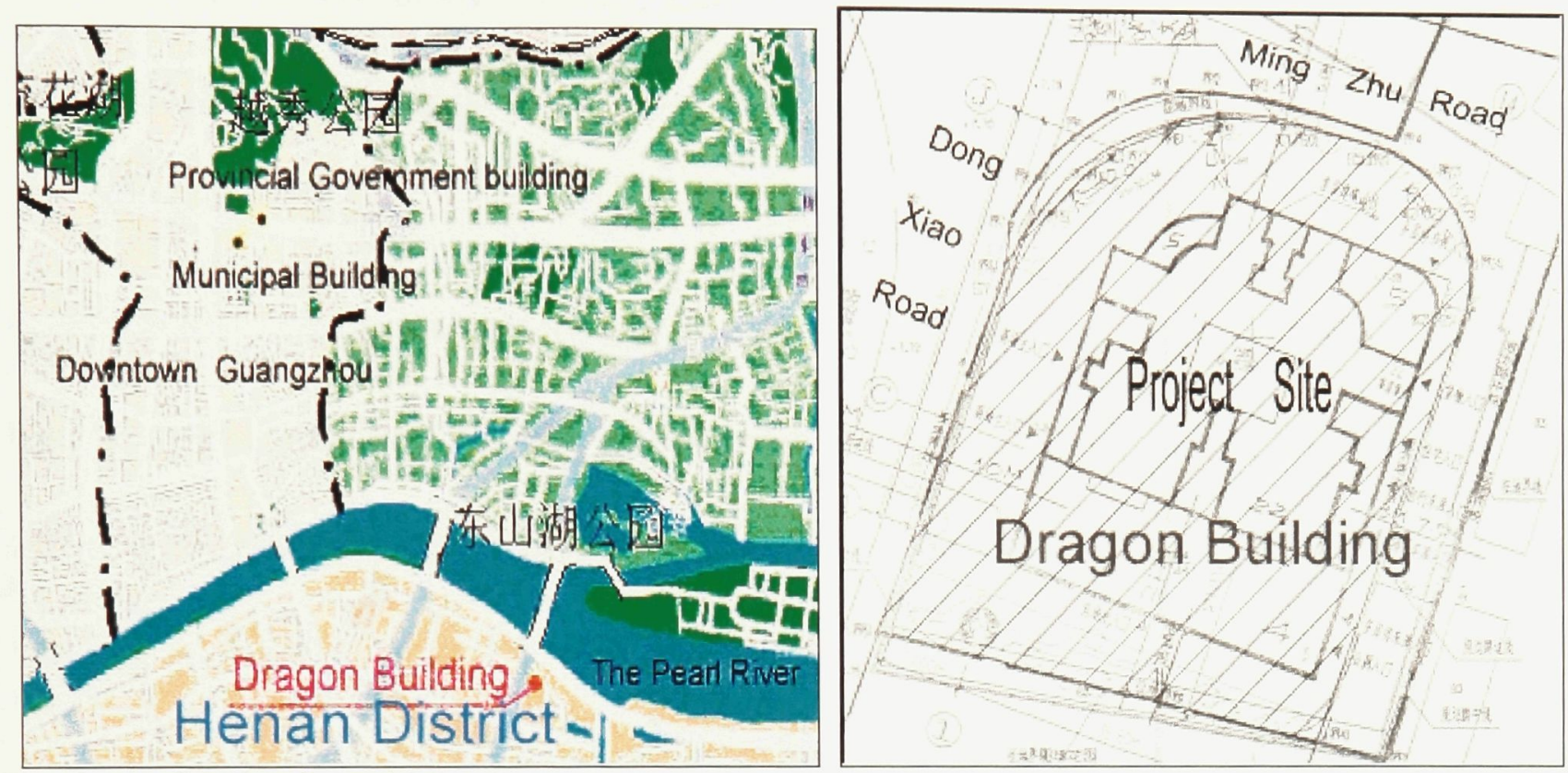

Figure 5.1 Selected Project Site and Location

The selected site (Figure 5.1) is located in the southeast portion of Guangzhou, known as the Henan District. Henan, which means a place south of the river in Chinese (here referring to the Pearl River), was used as industrial and agricultural land up to the 1980s. Today, it has developed into one of most important residential zones in Guangzhou. Factories have moved to suburban areas and farms have given way to residences, shops and office buildings. As a newly developing district, Henan's land and housing prices are on average $\$ 300$ per square meter lower than in the traditional urban core. The price discrepancy attracts people who cannot otherwise afford expensive housing in downtown. Newcomers, relocated families and young couples are the majority of homeowners in this new developing area.

The building is situated $2.2 \mathrm{~km}$ south of downtown and resembles a peninsula encircled by three roads. The building is bounded on the west and north by two arterial roads, Mingzhu 
Road and Dongxiao Road, the latter of which is connected to a busy bridge that crosses the Pearl River. On the east side of the building, there is another planned $15 \mathrm{~m}$ wide road that isolates the building from other buildings. A busy bus stop, used by 20 routes, is also located on Dongxiao Road. Indeed, convenient public transit is an important advantage of this site. As well, the distance between the site and the Pearl River is about two hundred meters, and there are only a few multi-story buildings between the building and the river. Therefore, apartments on the north side of the building will have a beautiful river view, which means that those residents will also be expected to pay a higher price.

This site is approximately $3,200 \mathrm{~m}^{2}(68 \mathrm{~m}$ by $53 \mathrm{~m})$, and the floor area ratio is 5.3 . The project, named the 'Dragon Building,' is a multifunctional development, consisting of two major uses: a wholesale commercial market in the podium and residences in the high-rise tower.

\subsection{Design Principals}

Brower (1996) describes four distinctly different types of neighbourhoods in his book Good Neighbourhood: Center Neighbourhoods, Small-town Neighbourhoods, Retreat Neighbourhoods and Residential Partnerships Neighbourhood. By his definition, a retreat neighbourhood has the weakest sense of community and offers residents few connecting facilities within the neighbourhood area. A retreat neighbourhood focuses on the individual rather than the community; it is private and secluded. In this neighbourhood, it is difficult to create a close-knit community of individuals, and people who live in retreat neighbourhoods are encouraged to be self-centered and largely disregard the interests of others. Though retreat neighbourhoods 
provide a reasonable housing choice for some people, in our view, it should not be a mainstream housing choice.

Unfortunately, many previous high-rise designs in Guangzhou have created this kind of neighbourhood in the last decade. Though the quality of life has increased in much of the high-rise housing stock, many residents still complain about insufficient, green space and recreation facilities in their neighbourhood. These spaces are very important communal areas that provide an area for social interaction with neighbours. Telephones, cell phones, air-conditioners, and especially the Internet, have reduced the need for face-to-face contact and interpersonal interaction. It is not surprising to see that people living in high-rise residences know fewer of their neighbours than people living in multi-story and low-rise housing units.

Based on our survey results, we are introducing some innovations into this project including:

- Maintaining the existing mixed-use areas (commercial and residential);

- Creating vertical open space and green streetscapes;

- Enhancing the neighbourhood feeling;

- Promoting community interaction in a vertical residential environment;

- Redesigning the community center based on survey results concerning community interests; and

- Studying the economic feasibility of neighbourhood innovations, so they are acceptable to both developers and home buyers.

The proposed building will be "able to create a harmonious, cooperative and immediate neighbourhood in a vertical setting," as well as incorporate neighbourhood variables into the 
design.

\subsection{Concept Design}

The original function of a neighbourhood in China was as an administrative and political system dividing the community into small groups of about twenty households. Today, in high-rise buildings, neighbours on each floor form the basic neighbourhood unit. However, according to the survey, residents living in high-rises only know about $54 \%$ of their neighbours on the same floor. Neighbours on the same floor are people who can provide immediate support and establish close relationships more easily than other residents. To cite another old Chinese saying, " $a$ neighbour close by is better than a relative far away." The reason that high-rise residents do not know many next-door neighbours is possibly because they do not have adequate public space on their floor. Recently, developers have reduced the amount of public areas in buildings, since, in their view, these places do not generate a profit. Hallways, elevators, and lobbies are now the only public spaces. Understandably, residents do not want to spent time in such narrow and uncomfortable places and tend to enter their homes as quickly as possible. It is not surprising, then, that people do not know many of those who live on the same floor. The following is a list of features to be incorporated into design to attempt to remedy this situation.

\section{- Communal Dooryard}

Previous design for this type of project consists of point-block high-rise buildings, with dark, unattractive hallways and a narrow elevator lobby (see Figure 5.2). In order to improve the neighbourhood feeling, a 'patio' concept is introduced into the design. In traditional Guangzhou 


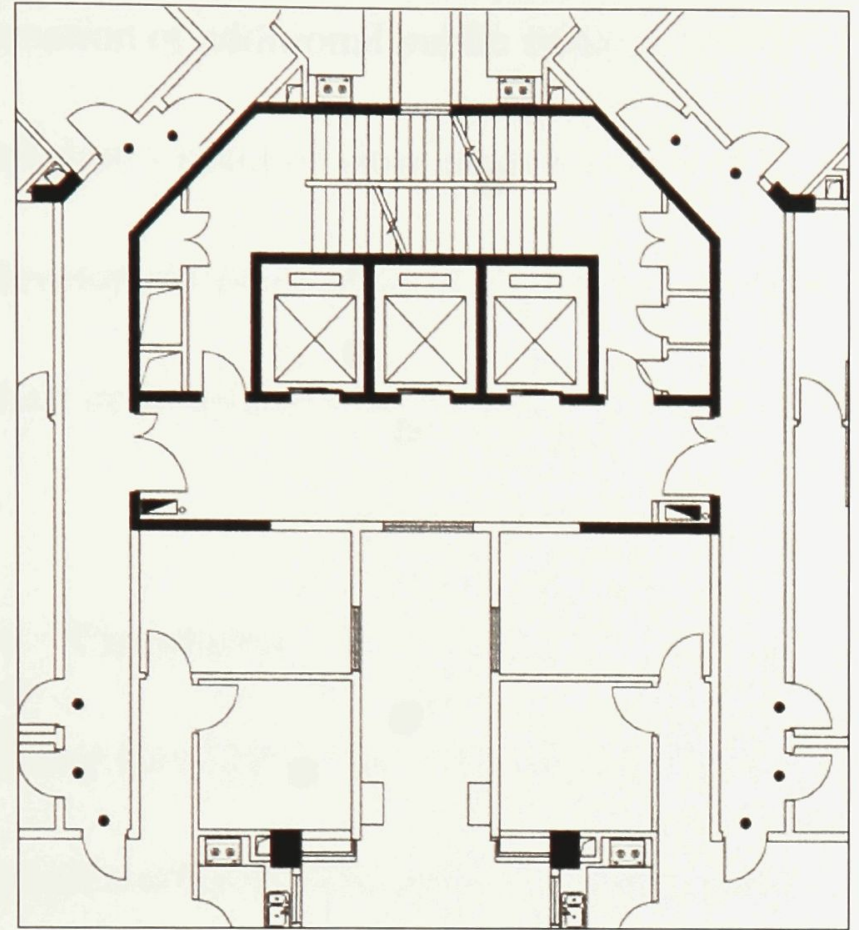

Figure 5.2 Typical Floor Plan (Original)

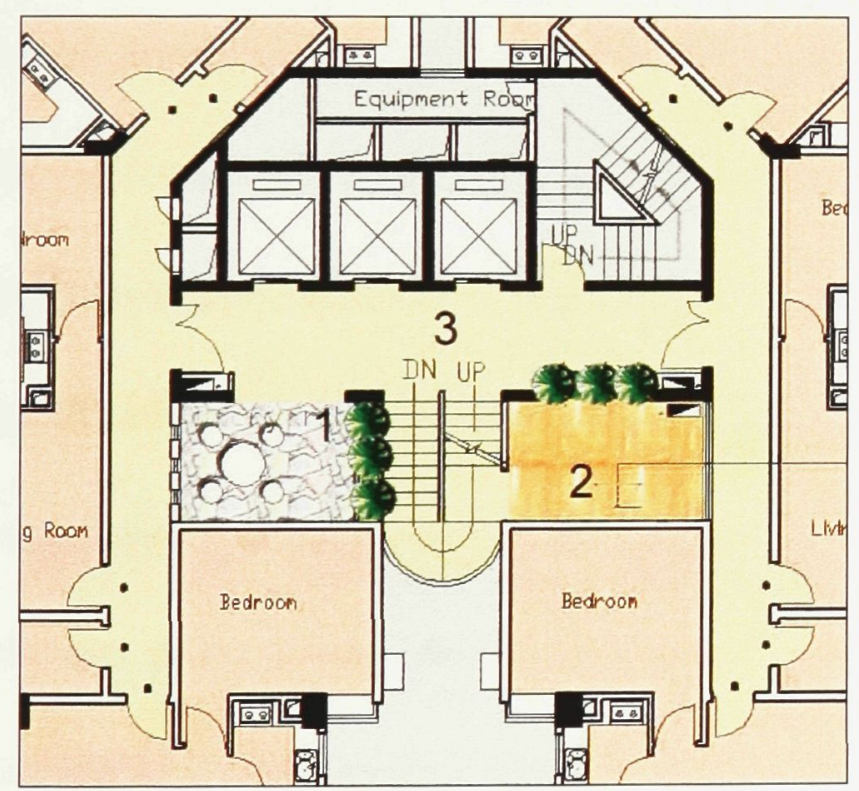

Figure 5.3 Typical Floor Plan (New) housing, the patio acts as a communication

"viaduct", a place where people can

enjoy the outdoors with others. In this design, a dooryard of twelve square meters is added to each floor (see Figure 5.3). The patio directly connects with the elevator lobby and allows for enhanced circulation. Therefore, when people come out of the elevator, they can step into the yard and greet or talk with their neighbours. In addition, the patio is not an enclosed space: an architectural gap is open on the south side of the patio. The patio not only has sunshine every day but also good ventilation in the summer time (the prevailing summer winds direction in Guangzhou are southeast $15^{\circ}$ ). There will also be some chairs and tables in the courtyard where people can sit, read and play games.

This transitional space may also increase the

1. Dooryard (Patio); 2. Playground; 3. Feature Stairs time spent in public. People can go into the sky court when they are waiting for the elevator, hopefully improving residents' satisfaction with elevator service and with the building overall. The patio can continue to function as it would in a 
traditional Chinese residence and become an important part of public life. The idea behind the creation of additional public space is likely to benefit to both residents and developers. From a resident's point of view, presumably them overall satisfaction level will rise. From the developer's point of view, they will be able to change the selling prices for their units, reduce their costs and, indeed, increase their profits too.

\section{- Circulation}

Yeang Ken (2002) has redefined the function of circulation in designing high-rise neighbourhoods. The pathways taken in high-rises should not only focus on the origin destinations and modes of transportation, but also understand the role of such journeys, and their social, economic and environmental effects as well. Optimum elevator service is a prerequisite for successful development of high-rise dwellings - it is a very important factor in neighbourhood satisfaction, according to our survey. Here are three suggestions to improve the quality of the elevator service. Firstly, a spacious lobby with plants and furniture acts as a welcoming waiting place. Secondly, the dooryards give residents a pleasant space waiting for the elevator going down. Thirdly, residents will have another pleasant mode of transportation - a feature stair case, which will alleviate some of the burden on the elevators (see Figure 5.3). Stairs, once the major vertical transit method, have gradually lost their importance in high-rise designs. Fire exit stairs are designed to be as narrow as possible and usually depend solely on artificial and emergency lighting. People are thus deterred from using the stairs, and many feel unsafe doing so; only fifteen percent of respondents in our survey commonly used the stairs. However, 
stairs act not only as a transit way, but also as an informal socializing space that connect residents in the same building. If people living in multi-story buildings spent more time on the stairs, they would have more chance meetings. Well-lit and appealing feature staircases and mezzanine levels can significantly increase interaction. This is one of the reasons why people living in multi-story dwellings know more neighbours than those living in high-rise residences, even though there are more housing units in high-rise buildings (see Figure 5.4).
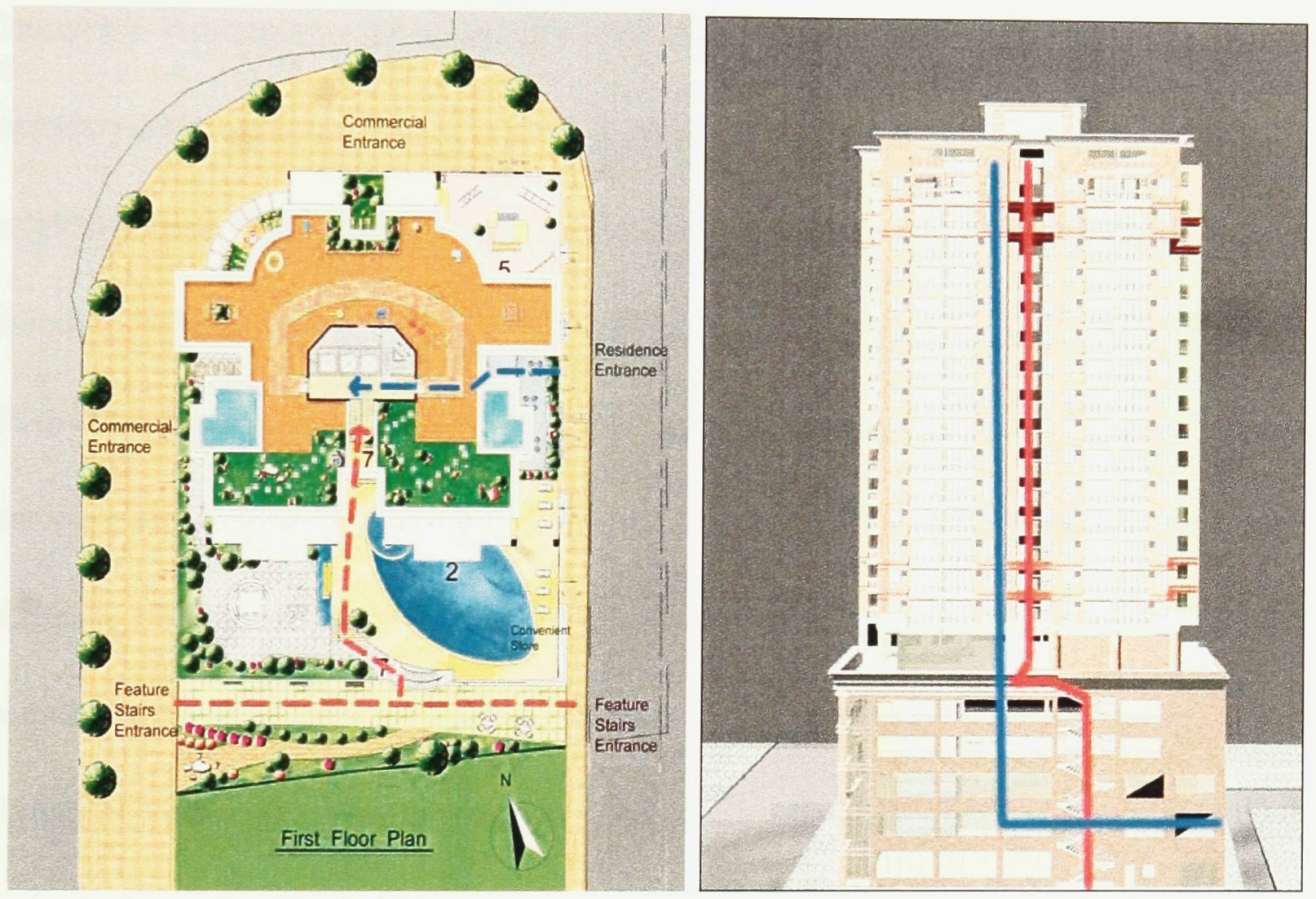

Figure 5.4 New Concept Design Circulation Organizations. Blue Line: Elevator. Red Line: Feature Stairs

Staircases in previous design consist of two narrow, single-flight stairs in a dark space

(see Figure 5.2). It is obvious that few residents would want to use these stairs unless there was a fire. A feature staircase will replace one of these fire escape staircases in our new design.

Featuring large windows and better materiality, the stairs will connect with the outside 
environment, attracting residents who wish to enjoy fresh air and sunshine while going up or down. Walking stairs can also become a popular daily exercise among high-rise residents. This feature will not only increase the chance of social interaction and relieve the burden on the elevators, but also make residents feel more satisfied with their residential environment.

\section{- High-rise Playgrounds}

One of the shortcomings of our survey done in Guangzhou is that the sample population does not include younger people. Children are an important component of the family and the neighbourhood. Their requirements should not be neglected in the design process. The main problem with raising children in a high-rise is that they do not have much open space to play in. Traditional housing uses streets and playgrounds - for games and other activities where children can socialize. Indeed, streets and sidewalks are the favorite place for children under 17 years (Chawla, 1992). In Guangzhou, due to environmental pollution, security and traffic problems, parents are often worried about their children playing outside their residences. Apartments in Guangzhou have only limited space for children and also lack outdoor open space. Therefore, we feel that it is essential to add sky courts for young residents (see Figure 5.3).

Eleven square-meter playgrounds were incorporated for each pairs of floors, and connected to the feature staircase. These courtyards are bounded inside the building and will be safe for children of all ages. Because of Chinese family policies and the transition to an urbanized condition, twenty eight percent of high-rise families in the survey have a child under age 10, which means that approximately 3 children live on each floor. Thus, a playground on 
each floor is not economical. As well, sharing a playroom with different floor residents allows children to have friends throughout the building and also gives opportunities for social interaction for parents and grandparents on different floors. In addition, these six-meter high spaces will enrich the spatial dimension in a high-rise housing project.

\section{- Vertical Landscape}

The vertical landscaping in this project includes two parts: a roof garden and a flower terrace on each floor. One of the best methods to increase green space is to use roof space efficiently. For a long period of time, the roofs of high-rises have been forgotten and left vacant (see Figure 5.5).

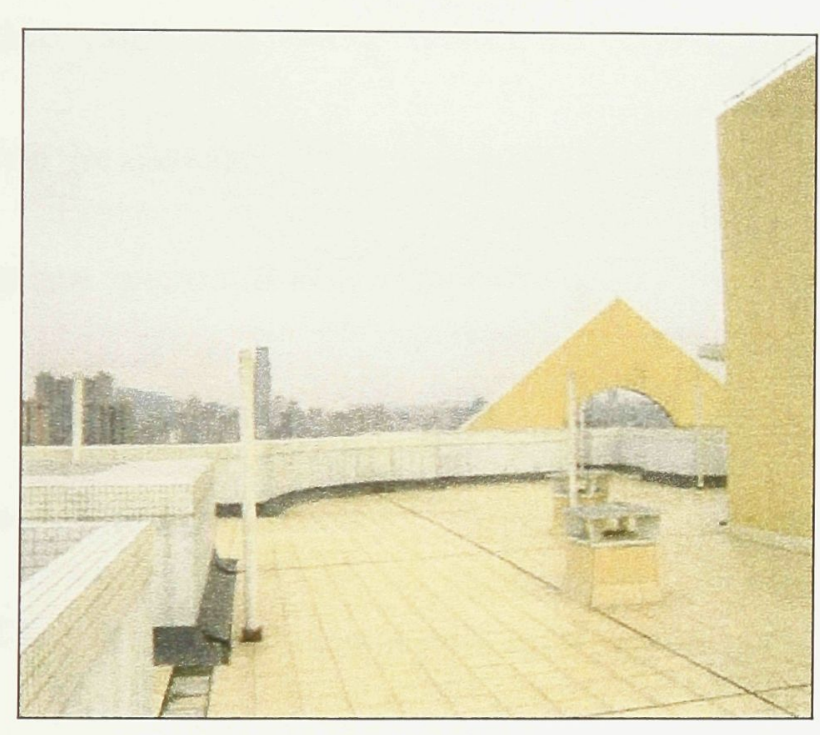

Figure 5.5 Original Roof Design

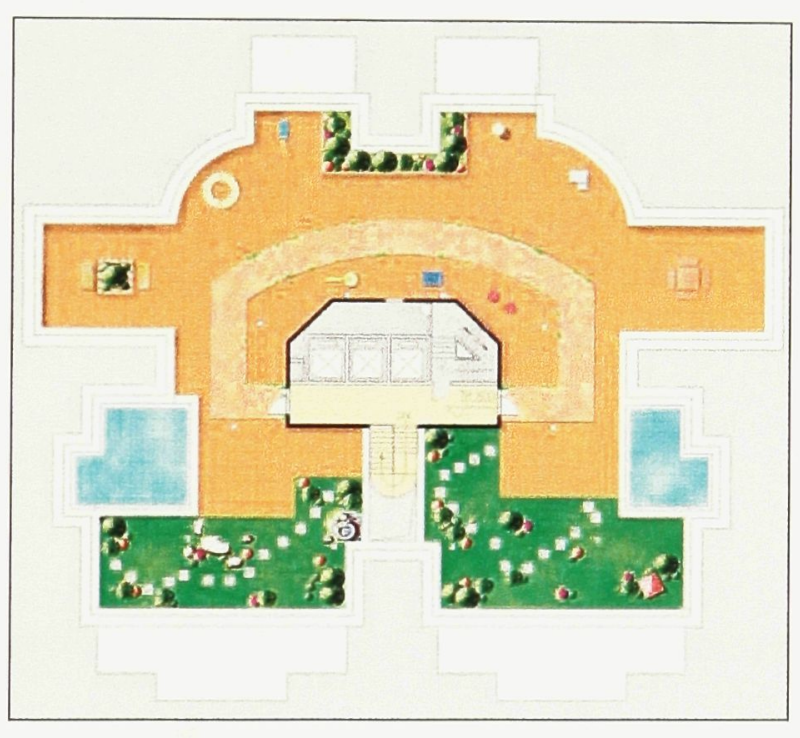

Figure 5.6 New Roof Garden

However, the function of these roofs has been reconsidered in recent years, and using the roof to supplement ground-oriented green space is currently accepted by many designers and developers. In other, older urban districts of Guangzhou, roof gardens were added to design regulations in 2002. Aside from increasing green space, roof gardens can also be an effective cooling device for the top floor - and also for the city, absorbing carbon dioxide and other vehicle emissions and 
breaking up the concrete urban scene. In addition, the roof garden is a good community place (see Figure 5.6). People can exercise on the roof and enjoy fresh air and the urban landscape. People who enjoy horticulture can take the responsibility of managing this space, sharing experiences and beautiful plants with other neighbours. It can improve the participation of the neighbourhood and thus integrate dispersed residents. Of course, the roof garden will necessarily add to construction costs, but considering neighbourhood benefits, a roof garden is worth it.

Hence, a $500 \mathrm{~m}^{2}$ roof-garden will be designed as the major open landscape in this project.

In order to create a vertical green system, flower terraces will be added to each elevator lobby, which can bring vitality into lifeless spaces. The interior plants will make the communal dooryards and lobbies more attractive and comfortable, and people will be calmer while waiting for the elevator. Thus, vertical landscaping will not only helps solve the problem of the lack of green space but also improves morale and the neighbourhood feeling.

\section{- The Community Center}

The community center will serve as the major communal space in high-rise design, becoming the focal point for community life. In this project, the community center or residential club will be built on the sixth floor, the stilted storey. The entire floor area is about $1,850 \mathrm{~m}^{2}$ and interior space will be $870 \mathrm{~m}^{2}$ (see Figure 5.7). 


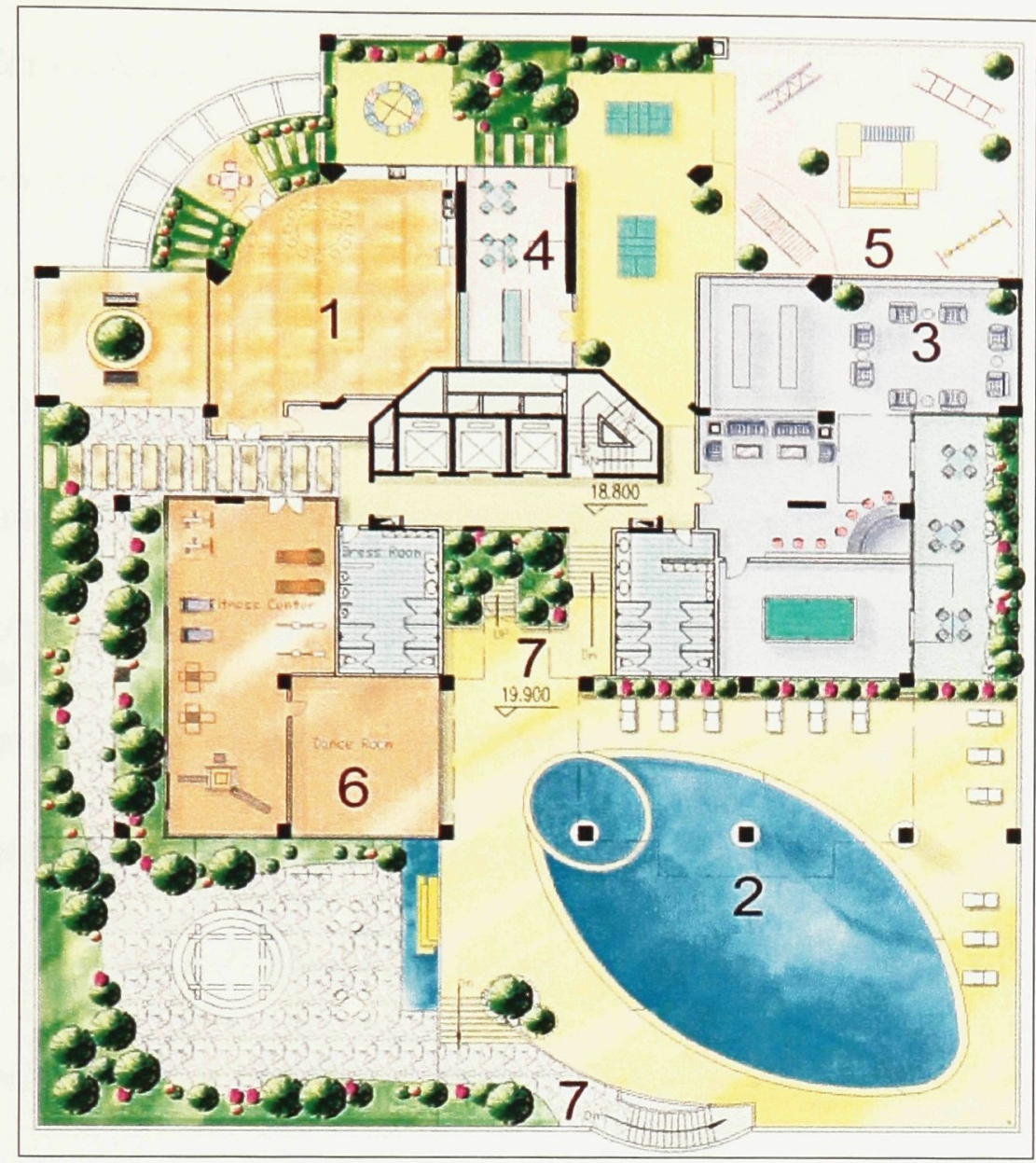

1. Resident Hall

2. Swimming Pool

3. Residence Library and Bar

4. Children Library

5. Outdoor Children Playground

6. Fitness Center

7. Feature Stairs

Figure 5.7 Community Center

According to our survey, the three most preferred community activities in Guangzhou are: sports, exercise and eating. In order to fulfill the demands of residents, a fitness room and some sports facilities, such as ping-pong tables, snooker tables, basic exercise equipment and a swimming pool, will serve as the hub of the residents' club. Swimming is a sport suitable for people of any age, and family members can participate together. Neighbours as well can get together to relax and play water sports during the summer. In this casual environment, people will be more willing to share their feelings with one another. Thus, the swimming pool becomes a real neighbourhood center in the high-rise, similar to the traditional corner store or local bar. Another design innovation is the provision of kitchen facilities in the resident hall. Adding 
a large kitchen here has two purposes: first, to allow for communal meals and second, to provide for cooking classes people in the neighbourhood. Based on the survey, enjoying delicious food is an important part of life in Guangzhou. People have stringent criteria for evaluating food,

whether eating outside or at home. Housewives, especially those just married, are willing to learn cooking experiences from others and will readily attend such activities. The classes also become an informal neighbourhood meeting space and integrate residents into the community. The main objective is thus not to learn cooking skills but to bring neighbours out from their isolated boxes, to get know each other and share information. Creating this community feeling is a very important aspect in neighbourhood development.

As well, the public kitchen and dining hall can give residents a place to host guests and relatives. The dining and kitchen area in each apartment is not big enough to host many guests. This dining hall will thus provide another choice for residents: having dinner in a beautiful garden and enjoying night scenes of the Pearl River. This warm and communal setting will almost certainly increase residents' satisfaction with their housing environment and consequently influence the vitality of the neighbourhood.

\subsection{Economic Study and Follow-up Survey}

A real estate project is successful if it meets both design and economic objectives. There is only a $40 \mathrm{~m}^{2}$ decreases in overall floor space after our redesign. However, in order to add neighbourhood design factors into the original design, the construction cost per square meter will increase $8 \%$, from $\$ 250 / \mathrm{m}^{2}$ to $\$ 270 / \mathrm{m}^{2}$, and the total construction cost will increase by $\$ 524,960$ (see Table 
5.1). High-rise residence prices in nearby areas is about $\$ 620$ per square meter, thus total revenue lost in residential area is $\$ 23,560$. The developer will lose $\$ 548,520$, or about twenty percent of the original profits if prices remain unchanged. Developers tend to seek maximum profit, and will not accept a design that will cause this level of lost profit. Thus, residents will have to share the cost. If residential sales prices are raised by six percent, the total loss will be less than $\$ 1,000$, which should be acceptable to most developers.

Table 5.1 Economical Feasibility Study

\begin{tabular}{|c|c|c|c|}
\hline & Previous Design & Innovation Design & Balance Profit \\
\hline Site Area (S) & $4,760 \mathrm{~m}^{2}$ & $4,760 \mathrm{~m}^{2}$ & $4,760 \mathrm{~m}^{2}$ \\
\hline Floor Area Ratio* & 5.23 & 5.22 & 5.22 \\
\hline Residential Area ( R) & $14,757 \mathrm{~m}^{2}$ & $14,719 \mathrm{~m}^{2}$ & $14,719 \mathrm{~m}^{2}$ \\
\hline Commercial Area (C) & $5,570 \mathrm{~m}^{2}$ & $5,570 \mathrm{~m}^{2}$ & $5,570 \mathrm{~m}^{2}$ \\
\hline Public Parking $(\mathrm{P})$ & $3,710 \mathrm{~m}^{2}$ & $3,710 \mathrm{~m}^{2}$ & $3,710 \mathrm{~m}^{2}$ \\
\hline Basement Area(B) & $1,855 \mathrm{~m}^{2}$ & $1,855 \mathrm{~m}^{2}$ & $1,855 \mathrm{~m}^{2}$ \\
\hline Other Area $(\mathrm{O})$ & $869 m^{2}$ & $869 \mathrm{~m}^{2}$ & $869 \mathrm{~m}^{2}$ \\
\hline Overall Floorage** & 26,761 & 26,723 & 26,723 \\
\hline \multicolumn{4}{|l|}{ Investment } \\
\hline Land cost $\left(\$ 400 / \mathrm{m}^{2}\right)$ & $\$ 1,904,000$ & $\$ 1,904,000$ & $\$ 1,904,000$ \\
\hline construction cost per $\mathrm{m}^{2}$ & $\$ 250$ & $\$ 270$ & $\$ 270$ \\
\hline construction cost & $\$ 6,690,250$ & $\$ 7,215,210$ & $\$ 7,215,210$ \\
\hline Total & $\$ 8,594,250$ & $\$ 9,119,210$ & $\$ 9,119,210$ \\
\hline \multicolumn{4}{|l|}{ Incomes } \\
\hline Residential Area $\left(\mathrm{m}^{2}\right)$ : & 14,757 & 14,719 & 14,719 \\
\hline Residence Sale Price & $\$ 620$ & $\$ 620$ & $\$ 657$ \\
\hline Sales Amount & $\$ 9,149,340$ & $\$ 9,125,780$ & $\$ 9,673,327$ \\
\hline Commercial Sale Area $\left(\mathrm{m}^{2}\right)$ & 3,710 & 3,710 & 3,710 \\
\hline Sale Price $\left(\mathrm{m}^{2}\right)$ & $\$ 1,000$ & $\$ 1,000$ & $\$ 1,000$ \\
\hline
\end{tabular}




\begin{tabular}{|l|c|c|c|}
\hline Sale Amount (50\%) & $\$ 1,855,000$ & $\$ 1,855,000$ & $\$ 1,855,000$ \\
\hline Annual Rent rate per $\mathrm{m}^{2}$ & $\$ 600$ & $\$ 600$ & $\$ 600$ \\
\hline Rent Income (30\%) & $\$ 667,800$ & $\$ 667,800$ & $\$ 667,800$ \\
\hline & & & 120 \\
\hline Parking & 120 & 120 & 50 \\
\hline Sales Parking (50 parking) & 50 & 50 & $\$ 7,500$ \\
\hline Sale Price & $\$ 7,500$ & $\$ 7,500$ & $\$ 375,000$ \\
\hline Sale Amount & $\$ 375,000$ & $\$ 375,000$ & $\$ 750$ \\
\hline Rent rate (annual) & $\$ 750$ & $\$ 750$ & $\$ 37,500$ \\
\hline Rent Income (50 Parking) & $\$ 37,500$ & $\$ 37,500$ & \\
\hline & & & $\$ 11,903,327$ \\
\hline Sales Total & $\$ 11,379,340$ & $\$ 11,355,780$ & $\$ 2,784,117$ \\
\hline Profit & $\$ 2,785,090$ & $\$ 2,236,570$ & $\$ 705,300$ \\
\hline Rent Income Total (annual) & $\$ 705,300$ & $\$ 705,300$ & \\
\hline
\end{tabular}

* means floor area ratio $=(\mathrm{R}+\mathrm{C}+\mathrm{P}+\mathrm{O}) / \mathrm{S} \quad * *$ Overall Floorage $=\mathrm{R}+\mathrm{C}+\mathrm{P}+\mathrm{B}+\mathrm{O}$

A follow-up survey was done in Guangzhou in February, 2005. One hundred letters were sent to the addresses randomly selected from previous survey respondents, and within two weeks 65 surveys (65\%) had been returned. In the survey, respondents were asked if they would pay six percent more to increase the facilities in their neighbourhood, including features such as dooryards, roof gardens, feature stairs and swimming pool. Thirty seven (57\%) of the respondents said that they would pay the additional money for these improvements. These respondents typically had a higher level of education and household income and were younger compared with the people who would not accept an increased budget. The positive responses were from people who had lived a shorter period in their residence and had a lower level of satisfaction with their neighbourhood. $73 \%$ of respondents complained about insufficient open and green space. Nearly $62 \%$ of respondents also thought there were insufficient sport and 
recreation facilities in their current neighbourhood. These figures were somewhat higher than the figures in the first survey.

People with a higher level of education and income level are more dissatisfied with their current dwelling quality are more willing to bear the burden of improvements to their living space. And when people were asked about the reason why they did not like with the new design, $46 \%(n=13)$ of respondents said they would not be able to afford it, and $21 \%$ of respondents $(n=6)$ said they did not think that they needed the improvements. Thus, the cost of neighbourhood design is still a barrier to acceptance of new design concepts.

A good neighbourhood and community feeling can help decrease the turnover rate of tenants and owners, lower vacancy rates - and increase prices and sales of new and existing dwellings. Parking and commercial space create a majority of the projects profit while sales of residential units will further improve the results from commercial sales. These benefits will certainly encourage developers to share part of the investment in a good neighbourhood. In 2002 , the average housing vacancy rate in Guangzhou was $9.5 \%$ and commercial area vacancy rate reached $23 \%$ (Stats, 2002). In a previous study, the assumption was that all residences are sold and that the vacancy rate in the commercial area was $20 \%$. However, it is very difficult to achieve this in an environment of furious competition, if there are not any innovations in design. Sound neighbourhood design attracts more buyers; it can not only enhance the success of a project. If neighbourhood design can reduce the vacancy rate by two percent (i.e., 3 more units sold), home buyers need only spend three percent more to experience a better designed environment. This creates a reasonable balance between homebuyers' goals and developers' 
pursuit of profit. 


\section{Chapter VI}

\section{Conclusion}

Twenty-five years of economic reform and 'open door' policy have resulted in great changes for people living in China: economic success, higher living standards, increasing household incomes; but also rampant urbanization and a deterioration of the country's environment. As one of the most popular Chinese development zones, Guangzhou is a typical expression of this revolutionary transformation. Often, traditional culture and social values have been abandoned or even ignored in the conversion. As well, new engineering technologies, architectural materials and theories, and living styles are imported from outside and have changed people's lives in the era of globalization.

Today, thousands of high-rise buildings have reshaped the skyline of the city and become a feasible living alternative for urbanites. The rapid urbanization process has dictated that high-rise housing will be a predominant housing style for the next twenty years in Guangzhou. High-rise housing has created new living models and new city fabrics. However, there are still many problems in contemporary high-rise residential design. Both designers and developers often lack a comprehensive understanding of the social effects when high-rise housing becomes the preferred dwelling style. High-rise building designs are mostly focused on aesthetic features and often neglect residential identity and psychological benefits. The neighbourhood study here has tried to correct some of the shortcomings in high-rise design and determine new guidelines that can help architects build healthy vertical neighbourhoods in Guangzhou. From previous 
studies, we conclude that several cultural differences between west and east are very important for high-rise design:

First, neighbourhood is perhaps best defined by a shared memory of neighbourhood boundaries, history and events. Chinese buyers tend to purchase their units and remain in those units for much longer periods of time than western buyers; thus, there exists more time for shared memories to accumulate. Home owners living in North America will change their residences an average of three times in ten years, whereas in Guangzhou, persons living in high-rises often remain there longer than a decade. This difference makes it more possible to establish neighbourhoods in Guangzhou's vertical environment, and designing a good neighbourhood environment may have more benefits than in Western societies.

Second, in Western vertical communities, activities are often provided by professionals hired by condominium management companies to conduct athletic or cooking programs, etc. In Guangzhou, the impetus will be placed on residents to create interest in the activities, as programming becomes a more important part of vertical community in China. Although Chinese activities and programming are not all together different than in the West, our survey shows that priorities in Guangzhou are different, with a strong emphasis on cooking, horticulture, walking and exercise.

Third, the physical quality of contemporary high-rise housing has reached the functional requirement of housing. For example, the average living area per person in Guangzhou has risen from $8 \mathrm{~m}^{2}$ to $27 \mathrm{~m}^{2}$, and in the survey, the data gives a figure of about $32 \mathrm{~m}^{2}$. Previous Chinese design in many ways resembles Western architecture themes, but it is time for Chinese architects 
to explore the life of its people. As well, the gap between youth and elderly is perhaps not as wide in China as the cultural divide between youth and the aged in North America. Young people have a similar longing for tradition and the design of vertical structures in Guangzhou should reflect this. While youth can create important virtual communities on the internet or through the use of cell phones, they do not replace the need for real live communities and neighbourhoods in Guangzhou.

What I have tried to do in this thesis is to add aspects to the design of high-rise buildings that reflect Chinese culture. The idea is to encourage spontaneous development of vertical communities without either adding huge costs or changing the design to something that the market will not accept. This is the most innovative and important point of this thesis. Because China has became part of the global community and Chinese people have access to the media and images of the West, there is a desire among residents in Guangzhou to acquire housing that is Western in structure but also expresses traditional Chinese culture. 


\section{Bibliography}

Ahlbrandt, Rogers S. Neighborhoods, People, and Community. New York: Plenum Press. 1984

Ahlbrandt, R. S., Jr., and Cunningham, J. V. A New Public Policy for Neighborhood Preservation. New York: Praeger, 1979.

Alexander, C., Ishikawa, S. Silverstein, M., \& Jacobson, M.. A Pattern Language: Towns, Buildings, Construction. New York: Oxford University Press, 1977.

Altman, I, The Environment and Social Behavior. Monterey, Calif.: Brooks \& Cole Publishing Company, 1975.

Altman, I. \& Chemers, M. Cuture and Environment. Monterey, Calif.: Brooks \& Cole Publishing Company, 1980

Altman, Irwin \& Wohlwill, Joachim, ed.. Human Behavior and Environment: Advances in Theory and Research. New York: Plenum Press. 1990.

Aregger, Hans. Highrise Building and Urban Design. Trans. Maria Kroll. New York: Praeger., 1967.

Blank, Grant, Ed.. Chinese Urban Reform: What Model now? Armonk, N.Y.: M. E. Sharpe, 1990.

Bourne, Larry S. The Geography of Housing. London: Winston, 1981.

Brownlee, Joanne. In Search of A Good Neighborhood. Winipeg: Institute of urban Studies, University of Winnipeg, 1995.

Brower, Sidney N. Good Neighborhoods: A Study of In-town \& Suburban Residential Environments. Westport, Conn.: Praeger, 1996.

Calthorpe, Peter. The Regional City: Planning for The End of Sprawl. Washington, D. C.: Island Press, 2001. 
Canter, D., and K. Rees. "A Multivariate Model of Housing Satisfaction.” International Review of Applied Psychology. 1982, 31, no. 2, 185-207.

Conway, Donald J.. ed.. Human Response to Tall Buildings. Stroudsburg, Pa.: Dowden, Hutchinson \& Ross, 1977.

Cooney, E. W. "High Flats in Local Authority Housing in England and Wales since 1945." In Multi Storey Living: The British Working Class Experience. Anthony Sutcliffe, ed. London: Croom Helm. 1974, $151-80$

Doheny-Farina, Stephen. The Wired Neighborhood. New Haven: Yale University Press, 1996.

De Vaus, D. A.. Surveys in Social Research. London: UCL Press; North Sydney, NSW, Australia: Allen \& Unwin. 1991.

Despres, C. "The Meaning of Home: Literature review and directions for future research and theoretical development." The Journal of Architectural and Planning Research. 1991, 8(2), 96-115.

Dreier, P. "The Status of Tenants in the United States." Social Problems. Buffalo, N. Y.: Society for the study of Social Problems, 1982, 30, 179-197.

Dunleavy, Patrick. The Politics of Mass Housing in Britain 1945-1975. Oxford: Clarendon Press, 1981.

Ermuch, F. Residential Satisfaction and Urban Environment Preferences. Toronto, Canada: York University, Atkinson College, 1974.

Fan, Y. "Brief Account of Beijing's High-rise Housing Development." Beijing Planning and Construction. $1988,4,36-38$

Festinger, Leon et. Social Pressures in Informal Groups. New York: Harper, 1950

Fowler, Floyd J.. Survey Research Methods. Thousand Oaks, Calif.: Sage Publications, 2002. 
Francescato, G., Weidemann, S., \& Anderson. J. R. "Residential Satisfaction: Its Uses and Limitations in Housing Research.” Housing and Neighborhoods. New York: Greenwood Press, 1987.

Frankenberg, Ronald. Communities in Britain: Social Life in Town and Country. Baltimore: Pengium Books, 1965.

Fried, Marc and Gleicher, P. "Some Sources of Residential Satisfaction in an Urban Slum." Journal.of the American Institute of Planners. Washington, D.C.: American Institute of Planners., 1961, pp. 305-315.

Galster, G. C. "Identifying the Correlates of Dwelling Satisfaction." Environment and Behavior, Beverly Hills, Calif.: Sage Publications. 19, 1987.

Galster, G. C. "Housing Satisfaction, Improvement Priorities and Policy Formulation." Environment and Behavior. Beverly Hills, Calif.: Sage Publications. 13, 1981.

Glass, Ruth. London: Aspects of Change. London: Maggibbon \& Kee., 1964.

Gottschalk, Trans. "Housing Study guild." Abstract of Papers at the Third International Congress at Brussels of the International Committee for the Solution of the Problems of Modern Architecture. 1935.

Greenberg, Mike. The Poetics of Cities: Designing Neighborhoods that Work. Columbus: Ohio State University Press, 1995.

Guo, Yonghai. Harmonizing Living and Working Spheres: An Architectural Manifestation in the Information Age. Ottawa: Master of Arch. Thesis. Carleton University, 2003.

Hallman, Howard W. Neighborhoods: Their Place in Urban Life. Beverly Hills: Sage Publications, 1984.

Hayden, Dolores. Building Suburbia: Green Fields and Urban Growth, 1820-2000. New York: Pantheon Books. 2003.

Hester, Randolph T. Planning Neighborhood Space with People. New York: Van Nostrand Reignhoold Co., 
1984.

Homenuck, Henry Peter Michael, Study of high-rise; effects, preferences and perceptions. Toronto: Institutue of Environment Research., 1973

Homenuck, Henry Peter Michael. An Overview Based on the Literature. Toronto, Canada: Institute of Environmental Research Inc. 1974.

Jacobs, Jane. The Death and Life of Great American Cities. New York: Random House, 1961.

Kateley. Richard. "Demand for High-rise Housing in the United States." Second Century of the Skyscraper. New York: Van Nostrand Rinhold Company, 1988, pp.465-472.

Keller, Suzanne. The Urban Neighborhood: A Sociological Perspective. New York: Random House, 1968.

Kempen, Eva van. "High-Rise Estates and the Concentration of Poverty." Willem van Vliet, Harvey Choldin, William Michelson, and David Popenoe ed. Housing and Neighborhoods: Theoretical and Empirical Contributions. New York: Greenwood Press, 1987, pp.191-214.

Langdon, P. A Better Place to Live: Reshaping the American Suburb. Amherest: The Univeristy of Massachusetts Press. 1994.

Lawrence, R. J. “What makes a house a home?” Environment and Behavior. 1987 19 (2), 154-168.

Lee, Terence. "Urban Neighborhood as a Socio-Spatial Schema." Environmental Psychology: Man and His Physical Settling. New York: Holt Rinehart and Winston, 1970, pp. 349.

Logan, John R., Ed.. The New Chinese City: Globalization and Market Reform. Oxford: Blackwell Publishers, 2002.

Mackintosh, E. A. "High in the City." Presented at the thirteenth annual conference of Environmental Design Research Association. College Park. 
Mann, Peter H. An Approach to Urban Sociology. New York: Humanities Press., 1965.

Marcus, Clare Cooper. Housing as if People Mattered: Site Design Guidelines for Medium-density Family Housing. Berkeley: University of California Press, 1986.

McCLAUGHERY, John. "Neighborhood Revitalization." In P. Duigan and A. Ravushka (ed.) The United States in the 1980s. Stanford, CA: Hoover Institutions Press., 1980.

Mehrabian, A. Public Places and Private Spaces: The Psychology of Work, Play, and Living Satisfaction. New York: Oxford University Press.

Michelson, William. Man and His Urban Environment: A Sociological Approach Reading. Reading, Mass: Addison-Wesley Publishing Co. 1970.

Mitchell, R. "Some Social Implications of High Density Housing." American Sociological Review. Menasha, Wis.: American Sociological Society., 36, 18-29, 1971.

Mumford, E. "The "tower in a park" in America: Theory and Practice, 1920-1960." Planning Perspectives. London: E. \& F.N. Spon, 1995, 10, 17-41.

Park, Robert Ezra, Ernest W. Burgess and Roderick D. Mckenzie. The City. Chicago: University of Chicago Press, 1967.

Perkins, D. D., Wandersman, A., Rich, R. C. and Taylor, R. B. "The Physical Environment of Street Crime: Defensible Space, Territoriality and Incivilities." Journal of Environmental Psychology. London: Academic Press, 1993, 13, 29-149/

Peterman, William. Neighborhood Planning and Community-based Development: The Potential and Limits of Grassroots Action. Thousand Oaks: Sage Publications, 2000.

Phillips, Patricia. Highrise of Homes / Site. New York: Rizzoli. 1982. 
Plunz, R. A History of Housing in New York City: Dwelling Type and Social Change in the American Metropolis. New York: Columbia University Press, 1990.

Porter, Douglas R.. Marking Smart Growth Work. Washington, D. C.: Urban Land Institute, 2002.

Rabrenovic, Gordana. Community Builders: A Tale of Neighborhood Mobilization in two cities. Philadelphia, Pa.: Temple University Press. 1996.

Rapoport. Amos. "Towards a Cross-Culturally valid Definition of Housing." Proceedings of the $11^{\text {th }}$ Environment Design Research Association. Washington, DC: EDRA Inc., 1980.

Ravetz, Allison. "Tenancy Patterns and Turnover at Quarry Hill Flats, Leeds." Urban Studies, Edinburgh, London: Longman Group Ltd. 1971,3, 181-205.

Rainwater, L. "Fear and the House-as-Haven in the Lower Class." Journal of the American Institute of Planners. Washington, DC: American Institute of Planners., 1966, 32. 23-31.

Ramirez, I. J. D. Effects on Residents' Attitudes of Social, Physical, and Environmental Aspects of High-rise Condominium Living in Metropolitan San Juan. Unpublished Ph.D. dissertation. The University of North Carolina, Greensboro.

Richman, Alan. "Planning Residential Environments: The Social Performance Standard." Journal of the American Planning Association, Washington, D.C.: American Planning Association. 45, 4, October 1979, pp. $448-457$.

Riger, S. "Ecological and Environmental Influences on the Individual." Psychology and Community Change: challenge for the future. Homewood, IL: The Dorsey Press, 1984, pp. 117-143.

Ritchie, Alan. "The Philosophy and the Future of the Skyscraper." In L. S. Beedle (Ed.). Second Century of the Skyscraper. New York: Van Nostrand Reinhold Company, 1988. pp.3-6. 
Rossum, J. A., J.F. van Hulst, and A. L. J. Goethals. Voorstudie naar het beheer en exploitatie van hoge woongebouwen. Amsterdam: Siswo. 1981

Salant, Priscilla. How to Conduct Your Own Survery. New York: Wiley, 1994.

Shan, Wenjiao. High-rise Buildings in Contemporary China. Ottawa: Carleton University. Unpublished Master thesis. 2004.

Stren, Richard, Ed. Urban Research in the Developing world. Toronto: Centre for Urban \& Community Studies. University of Toronto. 1994.

Suarez, Ray. The Old Neighborhood: What We Lost in the Great Suburban Migration, 1966-1999. New York: Free Press. 1999.

Supportive Housing: Neighborhood Fears and Realities. Toronto, Ont., : University of Toronto. 1994.

Unger, D. G., and Wandersman, A. "The Importance of Neighbours: The Social, Cognitive, and Affective Components of Neighboring." American Journal of Community Psychology. Kluwer Academic, Plenum Publishers. 1985, 13, 139-169.

Unger, D. G. \& Wandersman, A. "Neighboring in An Urban Environment." American Journal of Community Psychology. Kluwer Academic, Plenum Publishers. 1982, 10, 493-509.

Wang, Gungwu \& Wong, John, ed.. China: Two Decades of Reform and Change. Singapore: Singapore University Press, Singapore. New Jersey: World Scientific. 1999.

Weidemann, S. and Anderson, J. R. "Residents' Perceptions of Satisfaction and Safety: A Basis for Change in multifamily Housing." Environment and Behavior. Beverly Hills, Calif.: Sage Publications, 1982, 14, 695-724.

Wirth, Louis. "Urbanism as a Way of Life.” American Journal of Sociology. No.1 pp1-24. 
Wuthnow, Robert. Loose Connections: Joining together in America's Fragmented Communities. Cambridge, Mass.: Harvard University Press, 1998.

Yancey, W.L. "Architecture, Interaction and Social Control: The Case of a Large Scale Public Housing Project." Environment and Behavior. Beverly Hills, Calif.: Sage Publications. 1971, 1, 3-18.

Yeang, Ken. The Skyscraper Bioclimatically Considered: A Design Primer. London: Academy Editions, 1996.

Yeang, Ken. Reinventing the Skyscraper: A Vertical Theory of Urban Design. Chichester: Wiley-Academy, 2002.

Zhu, Jieming. The Transition of China's Urban Development: from Plan-controlled to Market-let. Westport, Conn.: Praeger, 1999. 


\section{APPENDIX A}

\section{Survey Questionnaire}

\section{Community Survey on Shared Experiences}

Wenxi He, an architecture Master student studying in Carleton University, carries out this survey. The major goal of this survey is to study the community and neighborhood relationship in the mega city, such as Guangzhou. We have a few questions we would like to ask you about your community. The information will only use for private study use.

\section{Part A Dwelling Information}

1. How long have you lived at your current address? years months

2. What kind of building do you live in?

Single-family home Townhouse

Multi-storey Apartment/Condo (4 storeys or less)

Multi-storey Apartment/Condo (five to ten storeys)

High-rise Apartment/Condo (More than ten storeys)

3. How old is the building?

Less than 3 years old

More than 3 and less than 6 years old

More than 6 and less than 10 years old

10 to 15 years old

15 to 25 years old

More than 25 years old

4. If you live in a multi-storey building, how many flats/apartments/condos are on one floor? flats/apartments/condos

5. How about the area of your house and how many bedrooms and bathrooms in your house?

sq $\mathrm{m}$ bedrooms Bathrooms

6. Do you rent or own the house you current live? rent

own 


\section{Part B Neighborhood Survey}

7. How many of your neighbours do you know on the floor where you live?

None 1 or 2 3 to 5

More than 5

8. How many of your neighbours do you know in the building where you live?
None
1 or 2
3 to 5
5 to 10
More than 10

9. If you live in a multi-storey building. do you want to know more of your neighbours? Yes No

10. If you answered 'no' to question 7, why do you not wish to know more of your neighbours?

11. Compared with the building you lived in before, do you feel safer and more secure in your current residence?

Yes

(If yes, please tell us why?)

No

(If no, please tell us why?)

12. Do you find any of these issues in your neighborhood?

Excessive Noise Yes/No

Vandalism

Yes / No

Graffiti

Yes / No

Pan Handlers / Beggars

Yes / No

Homeless

Yes/ No

Crime

Yes / No

Other (please specify):

13. Compared with the place where you lived before, how do you evaluate your participation in neighborhood activities? 
More Less Same

14. Have you attended any neighborhood activities?

Yes No

IF YES, what kind of activities have you participated in?

Festivals

Yes/No

Educational Seminars

Yes/No

Trade Shows

$\mathrm{Yes} / \mathrm{No}$

Conventions

Yes/No

Sporting Competitions

Yes/No

Artistic Performances

$\mathrm{Yes} / \mathrm{No}_{0}$

Exhibitions or Fairs

Yes/No

Other (please specify):

15. If your neighbor asked you to participate or volunteer in a neighborhood activity, you would:

Refuse to participate

Think about participating

Definitely participate

16. If you would not participate in neighborhood activities, can you tell us why?

17. If you would consider participating in a neighborhood activity, rate the following activities (from not very interested 0 or 1 to highly interested 9 or 10 ):

Professional Development

Horticulture

Video Games

Other Games

_ Shopping

Religion

Sports

Internet

Entertainment

Political

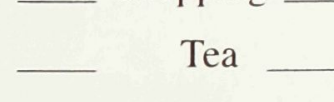

Current Affair Discussion Financial Forum

Reading

Art

Cleaning

Others (please specify): 
18. How frequently would you attend these neighborhood activities?

More than once per week

About once per week

About once a month

Annually or semi-annually

Other (please specify):

19. Comparing with the place you lived before, how do you evaluate the relation between you and your neighbours? Good__ Poor___ The Same

20. How satisfied are you with the overall quality of life in your neighborhood?

very satisfied

somewhat satisfied

unsatisfied

very unsatisfied

\section{Part C Living Habbits}

21. If you live in a multi-storey building, have you used the stair?

Yes

No

22. How many storeys would you be prepared to walk $\boldsymbol{u p}$ ?

None

One

Two to three

Three to five

More than five

23. How many storeys would you be prepared to walk down?

None

One

Two to three

Three to five

Five to ten

More than ten 
24. What is the thing you are most satisfied with in the building where you live?

Convenience Shopping Good Neighborhood

Well Residence Design

Safe Community Fine Public Traffic

Education

Enough Leisure and Recreation Facilities Social Relationship Open Space Quiet Environment Management Wonderful View and Scene

Other please specify:

25. What are the most dissatisfied things in your buildings?

Lack of Exercise Facilities Poor Management Inadequate Green Space Insufficient Open Space High Mortgage Costs High Rent High Operating Costs Poor

Neighborhood Bad Maintenance Polluted Environment Community Safety Dirty Environment

Other (Please Specify):

26. Do you enjoy or would you enjoy living in a high-density environment, such as urban core? Yes No

27. How would you evaluate the elevator service in your building? Acceptable Fair Unacceptable Not Applicable

28. What kind of services or facilities do you want to see added to your building or neighborhood in the future?

Please specify:

D. Personal Information

29. What is your occupation?

30. What is your gender?

Male

Female

31. What is your age? Years 
32. What is the highest level of education you have achieved:

Public School

High School

College

University

Post Graduated

33. What is your household income?

Less than $\$ 2,000$ USD per annum

$\$ 2,000$ to $\$ 5,000$ USD per annum

$\$ 5,000$ to $\$ 10,000$ USD per annum

$\$ 10,000$ to $\$ 20,000$ USD per annum

$\$ 20,000$ to $\$ 50,000$ USD per annum

More than $\$ 50,000$ USD per annum

34. How many other people in each of the following age groups reside with you in your household?

$0-10$ years

11-20 years

21-55 years

55 - 70 years

over 70 years

Thank you for participating in Wenxi He's Carleton University School of Architecture (Ottawa, Canada) Community Survey on Shared Experiences.

For further information, please contact Wenxi He: wenxiho@gmail.com 


\section{APPENDIX B}

\section{Survey Questionnaire (Chinese Version)}

\section{广州市邻里关系现状调查}

本次社会调有是由加拿人卡尔顿大学建筑系学生何文犧组织和发起的, 目的是研究现代建筑对人类的社 会关系的影响。谢谢你的积极参与, 如有任何问题可发 email 到以下邮箱： wenxiho@gmail.com, whe@connect.carleton.ca, 我将十分高兴解答你的疑问!

Part A 居住现状调查

1. 请问你已经在现住址居住多少年? 年

2. 请选择你的住宅的形式:

单栋别墅—联排住宅 (Townhouse)— (请跳到第 7 题)

低层住宅 (四层以下) — 多层住宅 (四层到九层)——高层住宅（九层以上）

3. 请问你所住的住宅的建成时间?
少于三年
3-6 年
6-10 年
10-15 年
$15-25$ 年
大于 25 年

4. 请问你所住的建筑每层有多少套单元呢? 套

5. 请问你的房子面积大概多少平米，有多少个卧室和洗手间? 平方米, 房, 则,

6. 请问你现在住的房子是租的, 还是白己的? 租的

自有物业

Part B 邻里状况调查

7. 请问你认识多少户住在同一层的邻居? 户

8. 请问你认识多少户住在同一栋大厦的邻居? 户

9. 如果有机会你有没有兴趣去结识多一点邻居? 有一没有

10. 如果你回答“没有”在第 7 题, 请简单说说你的理由。 
11. 利你以前所住的地方比较, 新的住宅能给你更多的安全感和保障感吗? 请你说说你的原网。 是的

。不是

12. 你又发现以下情况发生在你的社区周围对你造成影响吗?（多选）

制造噪声 损毁公物 涂损建筑 乱丢垃圾 占用公共地方

犯罪

其他（请说明）

13. 和你以前所住的地方比较, 你觉得你的邻里活动参与度是多少?

比以前多

比以前少

一样

14. 请问你有没有和邻居一起参加过社区活动? 有

没有

如果有, 请说说是那些社区活动?

\begin{tabular}{|c|c|c|c|c|}
\hline 节日庆祝 & 娱乐活动_ & 家长会 & 健身运动 & 购物活动 \\
\hline 艺术活动 & 其他 & & & \\
\hline
\end{tabular}

15. 如果你的邻居邀请你去参与一项社区公益活动, 你会:

拒绝参与

考虑参与

积极参与

16. 如果你不想参与邻居活动, 请简单说说你的理由:

17. 假如社区里会举行以下活动, 请用 10 到 1 米形容你对以下活动的兴趣 ( 10 是非常感兴趣的活动, 1 是不感兴趣的活动。)

\begin{tabular}{|c|c|c|c|c|c|}
\hline 烹调 & 职业拓展 & 电子游戏 & 其他游戏 & 闰艺 & 宗教 \\
\hline 网络社区 & 日常娱乐 & 政治 & 购物 & 时事研讨 & 财经 \\
\hline
\end{tabular}

其他感兴趣的活动（请说明） 
18. 你会经常参与这些活动吗?
多于每周一次
每周一次
每月一次
每季度一次
每年一次

其它（请说明）

19. 和以前你所住的地方比较, 你会如何形容你与邻居之间的关系。

好—差_——样_—

20. 你如何评价你的现在的邻里关系?

非常满意

满意

一般

不满意

非常不满意

Part C 你对现在居位环境的满意度

21. 如果你是住在有电梯的公寓里, 你有没有使用过楼梯呢? 有

没有

22. 你会愿意上多少层楼梯？ 不

1 层

2-3 层

3-5 层

多于 5 层

23. 你会愿意下多少层楼梯？不

1 层

2-3 层

3-5 层

多于 5 层

24. 你对目前所住的环境最令你满意的是 (多选):

购物方便—友好的邻里关系—住宅设计合理

社区安全

公共交通方便 教育配套完善 休闲娱乐设施齐全 方便人际交往 充足的活动和绿化 空间 环境安静 小区管理完善 景观好 其它（请说明）

25. 你对目前所住的环境最不满意的是 (多选):

健身设备不足

管理不善

房租太贵 水电杂费太贵

边治安差
绿化不够

邻居关系差 其它 (请说明)
户外活动空间不够

公共设施保养差
月供太高 污染严重 周

26. 你喜欢住在高密度的城市还是相对低密度的近郊, 如番禺、乐圃、黄村? 城市 近郊

27. 你如何评价你所住大楼里的电梯服务? 可以接受 一般 不可以 没有

28. 你最希望在你所住的社区里增加些什么服务或设施? 
Part D 个人资料

29. 你的职业是

30. 你的性别是 男

女

31. 你的年龄是 岁。

32. 你的教育程度是 初中及以下, 高中, 人专, 大学, 大学以上。

33. 你的家庭年收入是 小于 $¥ 30,000$ $¥ 30,000-60,000$ $¥ 60,000-90,000$ $¥ 90,000-180,000$ $¥ 180,000-450000$ 多于 450,000

34. 你的家庭组成是由多少个以下年龄的人组成? 0-10 岁 11-20 岁 21-55 岁 55-70 岁 大于 70 岁

非常谢谢你的耐心, 本次调查已经完成。你的积极参与是对我得很大鼓励！谢谢！如果你认为这次调查 有什么不足的地方, 请与本人联系, 你的意见间有助于我们提高调查的质量。衷心感谢你的参与! 


\section{APPENDIX C}

\section{FOLLOW-UP SURVEY LETTER}

Feb. $10^{\text {th }} 2005$

Dear Sir or Madam:

Thank you for your participation of our previous survey concerning the "Community Survey on Shared Experiences" in October 2004. From the survey, we found that respondents anticipate a better neighbourhood environment in their residences.

Based on that result, we plan to provide more neighbourhood facilities into high-rise buildings, such as feature stairs, playgrounds, public dooryards, roof gardens and more sport facilities. After these innovations, the average construction cost of the apartment will increase by about $6 \%$. Would you be willing to spend this extra money in order to get these improvements when you choose your new residences? Please send me your answer to the address above envelops.

Your response is very important for our study. Thank you again for your assistance in this research. If you have any questions, please email me at whe@ connect.carleton.ca.

Sincerely,

\section{Wenxi He}

Master Student

Department of Architecture,

Carleton University 


\section{APPENDIX D}

\section{FOLLOW-UP SURVEY LETTER (Chinese Version)}

亲爱的朋友们:

你们好！你们的支持使我们关于广州市的邻里关系调查获得了圆满的成功。通过这次调查, 我们发 现广州市居民对于住宅的环境仍未满意, 普遍认为缺之必要的开放空间, 绿化及运动设施。而缺乏 这些设施，会影响居民的邻里关系的建立和提高。

根据这个结果, 我们重新设计了一种能满足市民的要求的新高层住宅, 增加了必要的公共平台, 儿 童活动区, 屋顶花园, 开放式楼梯及健身设施例如游泳池, 老人健身径等等。新的设计的建筑成本 要比原设计高大概 $6 \%$, 也就是说售价要比原设计贵 $6 \%$ 。如果你作为一个头家, 你是否会选择这 种新的高层住宅? 请将你的答案发回到信封上的地址！

你的参与对我们的研究是十分重要的。如果你有任何疑问, 可以 e-mail:

次感谢你对我们研究的支持！

此致

敬礼

何文曦

卡尔顿大学, 建筑系 


\section{APPENDIX E}

\section{Correlate Matrix of Variables in High-rise Residences}

- Independent Variable: Neighbourhood Satisfaction (N)

- Physical Quality of Housing: 1. Length of Tenure; 2. Construction Time; 3. Unit Size; 4. Type of Ownership;

- Neighbourhood Description: 5. Same Floor Neighbours; 6. Same building Neighbours; 7.

Willingness to know neighbours; 8. Safety and Security; 9. Annoyance and Nuisances; 10.

Participation in Neighbourhood Activities; 11. Neighbourhood Comparison;

- Overall Residential Evaluation: 12. Environmental Satisfaction; 13. Dissatisfied Issues; 14. Residential Area Selection; 15. Elevator Service

- Socio-economic-demographic Data: 16. Gender; 17. Age; 18. Education Level; 19. Household Income; and 20. Family Population.

\begin{tabular}{|c|c|c|c|c|c|c|c|c|c|c|c|c|c|c|c|c|c|c|c|c|c|}
\hline & $\mathrm{z}$ & - & $N$ & $\omega$ & $\Delta$ & $u$ & $a$ & $\checkmark$ & $\infty$ & 6 & $\overline{0}$ & $=$ & $\bar{N}$ & $\bar{\omega}$ & $\bar{D}$ & $\bar{u}$ & $\vec{a}$ & $\Xi$ & $\varpi$ & $\varpi$ & $\tilde{o}$ \\
\hline Z & $\dot{8}$ & & & & & & & & & & & & & & & & & & & & \\
\hline- & $\begin{array}{l}\dot{\omega} \\
\underline{\omega}\end{array}$ & $\dot{8}$ & & & & & & & & & & & & & & & & & & & \\
\hline$N$ & $\begin{array}{l}\dot{D} \\
\text { N }\end{array}$ & $\stackrel{0}{\dot{\phi}}$ & $\dot{8}$ & & & & & & & & & & & & & & & & & & \\
\hline$\omega$ & $\begin{array}{l}\dot{D} \\
\text { N }\end{array}$ & 요 & $\begin{array}{l}\dot{0} \\
\text { i }\end{array}$ & $\dot{8}$ & & & & & & & & & & & & & & & & & \\
\hline 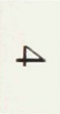 & ì & : & $\begin{array}{l}\dot{0} \\
\dot{9}\end{array}$ & i & $\dot{8}$ & & & & & & & & & & & & & & & & \\
\hline ur & $\begin{array}{l}\dot{0} \\
\text { i }\end{array}$ & $\stackrel{\bigcirc}{\triangleright}$ & $\frac{0}{\infty}$ & $\begin{array}{l}1 \\
0 \\
0\end{array}$ & $\stackrel{8}{8}$ & $\overline{8}$ & & & & & & & & & & & & & & & \\
\hline$a$ & $\dot{b}$ & $\stackrel{\circ}{\stackrel{\circ}{u}}$ & $\stackrel{\circ}{\infty}$ & $\stackrel{0}{\not}$ & $\stackrel{\bigcirc}{\infty}$ & $\stackrel{0}{\dot{b}}$ & $\dot{8}$ & & & & & & & & & & & & & & \\
\hline$\checkmark$ & 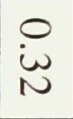 & $\begin{array}{l}0 \\
0 \\
0\end{array}$ & $\stackrel{0}{y}$ & $\stackrel{\dot{\omega}}{\omega}$ & $\begin{array}{l}\dot{0} \\
\dot{y}\end{array}$ & $\frac{\dot{b}}{\dot{u}}$ & $\frac{0}{\not}$ & $\overline{8}$ & & & & & & & & & & & & & \\
\hline$\infty$ & $\stackrel{\circ}{\omega}$ & $\begin{array}{l}1 \\
0 \\
0\end{array}$ & $\begin{array}{l}0 \\
\text { OO } \\
\text { i }\end{array}$ & $\dot{b}$ & $\frac{0}{a}$ & $\begin{array}{l}\dot{1} \\
8 \\
8\end{array}$ & $\frac{\dot{b}}{u_{1}}$ & $\begin{array}{l}\underset{\sim}{\infty} \\
\underset{\infty}{0}\end{array}$ & $\dot{8}$ & & & & & & & & & & & & \\
\hline 6 & $\stackrel{0}{0}$ & $\begin{array}{l}0 \\
0 \\
0\end{array}$ & $\begin{array}{l}\circ \\
8 \\
8\end{array}$ & $\begin{array}{l}\dot{0} \\
\text { in }\end{array}$ & $\stackrel{0}{\ominus}$ & $\dot{8}$ & $\frac{0}{a}$ & 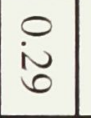 & $\begin{array}{l}\stackrel{ }{N} \\
\underline{-}\end{array}$ & $\overline{8}$ & & & & & & & & & & & \\
\hline$\tilde{0}$ & $\stackrel{O}{\stackrel{O}{u}}$ & $\begin{array}{l}\dot{b} \\
\dot{u} \\
u\end{array}$ & $\begin{array}{l}0 \\
=\end{array}$ & $\begin{array}{l}\dot{1} \\
\text { N } \\
\text { N }\end{array}$ & $\begin{array}{l}\dot{D} \\
\text { N }\end{array}$ & $\begin{array}{l}\dot{D} \\
\dot{u} \\
\text { un }\end{array}$ & $\begin{array}{l}0 \\
\dot{I} \\
\perp\end{array}$ & $\begin{array}{l}\text { O } \\
\text { i }\end{array}$ & $\begin{array}{l}\dot{0} \\
\dot{1} \\
\dot{1}\end{array}$ & $\frac{0}{0}$ & $\overline{8}$ & & & & & & & & & & \\
\hline
\end{tabular}




\begin{tabular}{|c|c|c|c|c|c|c|c|c|c|c|c|c|c|c|c|c|c|c|c|c|c|}
\hline 二 & $\begin{array}{l}0 \\
\text { in }\end{array}$ & $\begin{array}{l}\dot{0} \\
\omega\end{array}$ & $\begin{array}{l}\dot{b} \\
\text { w }\end{array}$ & $\frac{\dot{b}}{\omega}$ & $\frac{1}{\not}$ & $\begin{array}{l}b \\
\text { i }\end{array}$ & $\begin{array}{l}\dot{0} \\
\text { O }\end{array}$ & $\underset{\omega}{\omega}$ & $\stackrel{0}{\vec{A}}$ & 8 & i. & $\dot{8}$ & & & & & & & & & \\
\hline $\bar{N}$ & $\frac{b}{\dot{0}}$ & $\begin{array}{l}0 \\
8\end{array}$ & $\frac{b}{6}$ & in & $\frac{0}{6}$ & $\stackrel{\circ}{\circ}$ & $\begin{array}{l}\dot{0} \\
\dot{0}\end{array}$ & $\stackrel{b}{\text { D }}$ & $\begin{array}{l}\dot{0} \\
0\end{array}$ & O̊ & $\frac{b}{6}$ & $\begin{array}{l}\dot{\omega} \\
\dot{\omega}\end{array}$ & $\dot{8}$ & & & & & & & & \\
\hline $\bar{\omega}$ & i & $\begin{array}{l}1 \\
0 \\
0\end{array}$ & in & $\stackrel{b}{ \pm}$ & $\begin{array}{l}1 \\
0 \\
0\end{array}$ & $\begin{array}{l}\dot{0} \\
0 \\
0\end{array}$ & $\begin{array}{l}\dot{0} \\
\dot{\omega}\end{array}$ & O & 웅 & $\stackrel{0}{0}$ & $\frac{0}{6}$ & $\stackrel{0}{=}$ & $\underset{\infty}{\infty}$ & $\dot{8}$ & & & & & & & \\
\hline$\vec{D}$ & $\stackrel{0}{\not}$ & $\begin{array}{l}\dot{N} \\
\stackrel{D}{0}\end{array}$ & $\begin{array}{l}\text { o } \\
\text { un }\end{array}$ & $\begin{array}{l}0 \\
8\end{array}$ & $\stackrel{0}{0}$ & $\frac{b}{\infty}$ & $\begin{array}{l}1 \\
\text { O } \\
\text { O }\end{array}$ & $\begin{array}{l}0 \\
8 \\
8\end{array}$ & $\stackrel{0}{\omega}$ & $\stackrel{0}{\vec{\phi}}$ & $\stackrel{0}{0}$ & : & $\begin{array}{l}1 \\
0\end{array}$ & $\stackrel{0}{\dot{r}}$ & $\dot{8}$ & & & & & & \\
\hline $\bar{u}$ & $\begin{array}{l}\dot{0} \\
0 \\
0\end{array}$ & $\frac{b}{\dot{0}}$ & $\begin{array}{l}b \\
0\end{array}$ & $\begin{array}{l}1 \\
0\end{array}$ & $\frac{b}{0}$ & $\begin{array}{l}\dot{0} \\
\dot{0}\end{array}$ & $\begin{array}{l}\dot{0} \\
\dot{0}\end{array}$ & $\frac{\dot{0}}{\dot{u}}$ & $\frac{b}{a}$ & $\begin{array}{l}\circ \\
\varnothing \\
\varnothing\end{array}$ & : & $\underset{i}{\dot{D}}$ & $\stackrel{0}{\circ}$ & $\begin{array}{l}\dot{0} \\
0 \\
0\end{array}$ & $\stackrel{0}{n}$ & $\dot{8}$ & & & & & \\
\hline $\bar{a}$ & $\stackrel{b}{0}$ & $\frac{1}{0}$ & 용 & $\begin{array}{l}\dot{0} \\
\dot{0}\end{array}$ & 용 & $\stackrel{0}{+}$ & i & $\frac{1}{0}$ & $\stackrel{0}{0}$ & $\begin{array}{l}\dot{0} \\
\dot{0}\end{array}$ & 요 & $\frac{\dot{0}}{0}$ & $\frac{b}{N}$ & $\stackrel{0}{0}$ & $\begin{array}{l}b \\
0\end{array}$ & $\begin{array}{l}\dot{0} \\
\text { N }\end{array}$ & - & & & & \\
\hline$\exists$ & $\begin{array}{l}\dot{0} \\
\text { ᄋ }\end{array}$ & $\stackrel{0}{\text { N }}$ & $\stackrel{0}{0}$ & $\begin{array}{l}\dot{0} \\
\text { ㅁ }\end{array}$ & O̊ & $\underset{\infty}{\infty}$ & i & 8 & $\begin{array}{l}0 \\
\infty \\
\infty\end{array}$ & $\begin{array}{l}0 \\
i \\
\perp\end{array}$ & O̊ & $\begin{array}{l}0 \\
0\end{array}$ & $\begin{array}{l}\dot{0} \\
\text { N }\end{array}$ & ○̊ & $\stackrel{0}{i}$ & $\begin{array}{l}\dot{0} \\
8\end{array}$ & $\stackrel{0}{y}$ & $\dot{\varepsilon}$ & & & \\
\hline $\bar{\infty}$ & $\stackrel{0}{\dot{u}}$ & $\stackrel{\circ}{\circ}$ & $\frac{\dot{b}}{\omega}$ & $\underset{\infty}{\infty}$ & $\stackrel{0}{\infty}$ & $\begin{array}{l}0 \\
0 \\
0\end{array}$ & :ீ & $\stackrel{0}{=}$ & $\begin{array}{l}b \\
0 \\
0\end{array}$ & $\frac{b}{\pi}$ & $\begin{array}{l}\dot{b} \\
\dot{\omega}\end{array}$ & $\stackrel{0}{=}$ & $\stackrel{0}{0}$ & $\begin{array}{l}b \\
\text { ia }\end{array}$ & $\stackrel{\dot{0}}{\dot{N}}$ & $\stackrel{b}{=}$ & $b_{\infty}^{b}$ & ¿ & ஜ & & \\
\hline $\overrightarrow{0}$ & $\begin{array}{l}0 \\
\text { in }\end{array}$ & $\stackrel{\circ}{\infty}$ & $\begin{array}{l}1 \\
0 \\
0\end{array}$ & $\stackrel{0}{\text { un }}$ & $\frac{0}{6}$ & $\frac{\dot{b}}{\dot{0}}$ & $\stackrel{0}{0}$ & $\stackrel{\dot{\omega}}{\omega}$ & $\frac{1}{6}$ & $\begin{array}{l}\dot{0} \\
\text { 二 }\end{array}$ & $\begin{array}{l}1 \\
0 \\
0\end{array}$ & $\begin{array}{l}\dot{0} \\
\text { i }\end{array}$ & $\stackrel{0}{\infty}$ & $\underset{\omega}{\omega}$ & O̊ & : & $\begin{array}{l}\dot{0} \\
\text { i }\end{array}$ & $\stackrel{1}{i}$ & in & $\dot{8}$ & \\
\hline No & $\begin{array}{l}\dot{0} \\
0 \\
0\end{array}$ & iN & $\begin{array}{l}1 \\
0\end{array}$ & $\underset{\infty}{0}$ & 웅 & $\begin{array}{l}\dot{b} \\
\text { Na }\end{array}$ & $\frac{\dot{0}}{a}$ & $\begin{array}{l}1 \\
0\end{array}$ & $\stackrel{b}{\infty}$ & io & $\begin{array}{l}\dot{0} \\
0\end{array}$ & $\dot{b}$ & i & $\stackrel{b}{\omega}$ & i & $\stackrel{1}{\circ}$ & $\begin{array}{l}\text { b } \\
\text { w }\end{array}$ & $\stackrel{c}{c}$ & $\begin{array}{l}b \\
i\end{array}$ & in & - \\
\hline
\end{tabular}




\section{APPENDIX F}

\section{Correlate Matrix of Variables in Mid-rise Residences}

- Independent Variable: Neighbourhood Satisfaction (N)

- Physical Quality of Housing: 1. Length of Tenure; 2. Construction Time; 3. Unit Size; 4. Type of Ownership;

- Neighbourhood Description: 5. Same Floor Neighbours; 6. Same building Neighbours; 7.

Willingness to know neighbours; 8. Safety and Security; 9. Annoyance and Nuisances; 10.

Participation in Neighbourhood Activities; 11. Neighbourhood Comparison;

- Overall Residential Evaluation: 12. Environmental Satisfaction; 13. Dissatisfied Issues; 14. Residential Area Selection; 15. Elevator Service

- Socio-economic-demographic Data: 16. Gender; 17. Age; 18. Education Level; 19.

Household Income; and 20. Family Population.

\begin{tabular}{|c|c|c|c|c|c|c|c|c|c|c|c|c|c|c|c|c|c|c|c|c|c|}
\hline & Z & - & $N$ & $\omega$ & A & u & $a$ & $\checkmark$ & $\infty$ & 6 & $\overrightarrow{0}$ & $\Xi$ & $\bar{N}$ & $\bar{\omega}$ & $\mp$ & $\bar{u}$ & $\bar{a}$ & $\Xi$ & $\infty$ & $\overline{6}$ & $\tilde{0}$ \\
\hline Z & $\dot{8}$ & & & & & & & & & & & & & & & & & & & & \\
\hline- & $\frac{0}{6}$ & $\dot{8}$ & & & & & & & & & & & & & & & & & & & \\
\hline$N$ & 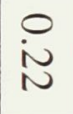 & $\stackrel{0}{\beth}$ & $\dot{8}$ & & & & & & & & & & & & & & & & & & \\
\hline$\omega$ & $\frac{\dot{o}}{\dot{u}}$ & $\begin{array}{l}\text { Oे } \\
\text { i }\end{array}$ & $\begin{array}{l}\dot{D} \\
\text { i }\end{array}$ & $\dot{8}$ & & & & & & & & & & & & & & & & & \\
\hline$\triangle$ & $\begin{array}{l}\stackrel{8}{9} \\
\dot{9}\end{array}$ & $\begin{array}{l}\dot{0} \\
\dot{\tilde{\sigma}}\end{array}$ & $\stackrel{8}{8}$ & 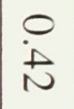 & $\overline{8}$ & & & & & & & & & & & & & & & & \\
\hline ur & $\begin{array}{l}\dot{0} \\
\text { î }\end{array}$ & $\begin{array}{l}\dot{0} \\
8\end{array}$ & $\frac{\dot{c}}{\dot{u}}$ & $\dot{0}$ & $\begin{array}{l}\dot{0} \\
\text { in }\end{array}$ & $\dot{8}$ & & & & & & & & & & & & & & & \\
\hline$a$ & $\frac{1}{6}$ & $\stackrel{0}{9}$ & $\stackrel{\circ}{\text { in }}$ & $\begin{array}{l}\dot{0} \\
\text { i }\end{array}$ & : & is & $\overline{8}$ & & & & & & & & & & & & & & \\
\hline$\checkmark$ & $\stackrel{\odot}{\circ}$ & $\begin{array}{l}\dot{1} \\
\dot{\omega}\end{array}$ & $\begin{array}{l}\dot{b} \\
\dot{v}\end{array}$ & $\begin{array}{l}\dot{0} \\
\dot{0}\end{array}$ & $\frac{1}{0}$ & $\frac{b}{\not}$ & $\frac{\dot{b}}{\not}$ & $\dot{8}$ & & & & & & & & & & & & & \\
\hline$\infty$ & 芫 & $\begin{array}{l}\text { Oे } \\
\text { Oे }\end{array}$ & $\frac{0}{\omega}$ & $\begin{array}{l}\dot{O} \\
\dot{\infty}\end{array}$ & $\frac{\dot{0}}{\dot{\omega}}$ & $\begin{array}{l}\dot{0} \\
0\end{array}$ & $\begin{array}{l}\stackrel{0}{0} \\
\dot{Q}\end{array}$ & $\begin{array}{l}\dot{C} \\
\dot{\omega}\end{array}$ & $\dot{8}$ & & & & & & & & & & & & \\
\hline
\end{tabular}




\begin{tabular}{|c|c|c|c|c|c|c|c|c|c|c|c|c|c|c|c|c|c|c|c|c|c|}
\hline 0 & 定 & $\stackrel{0}{0}$ & $\stackrel{0}{v}$ & ! & $\stackrel{0}{0}$ & $\begin{array}{l}\dot{0} \\
0 \\
0\end{array}$ & $\begin{array}{l}0 \\
\dot{N} \\
\dot{N}\end{array}$ & $\frac{\dot{0}}{n}$ & $\begin{array}{l}\stackrel{i}{N} \\
\stackrel{\sim}{*}\end{array}$ & $\overline{8}$ & & & & & & & & & & & \\
\hline $\bar{o}$ & $\stackrel{\stackrel{O}{\tilde{I}}}{\text { I }}$ & $\begin{array}{l}\circ \\
8\end{array}$ & $\begin{array}{l}0 \\
\dot{N} \\
\dot{N}\end{array}$ & $\begin{array}{l}0 \\
\dot{9}\end{array}$ & $\stackrel{0}{\circ}$ & $\begin{array}{l}1 \\
0 \\
0\end{array}$ & \begin{tabular}{l}
0 \\
0 \\
0 \\
\hdashline
\end{tabular} & : & $\begin{array}{l}\circ \\
8\end{array}$ & $\stackrel{0}{a}$ & $\dot{8}$ & & & & & & & & & & \\
\hline$\Xi$ & ن & $\stackrel{0}{0}$ & $\begin{array}{l}\dot{0} \\
\dot{0}\end{array}$ & $\stackrel{0}{\square}$ & $\frac{0}{0}$ & $\stackrel{0}{0}$ & $\stackrel{0}{\sigma}$ & : & $\stackrel{0}{N}$ & $\stackrel{0}{\grave{N}}$ & in & $\dot{8}$ & & & & & & & & & \\
\hline $\bar{N}$ & $\frac{\dot{O}}{n}$ & $\stackrel{0}{N}$ & $\begin{array}{l}\dot{0} \\
8 \\
8\end{array}$ & $\stackrel{\circ}{\infty}$ & $\stackrel{0}{=}$ & $\stackrel{\dot{b}}{\omega}$ & $\begin{array}{l}\dot{0} \\
\dot{9}\end{array}$ & $\begin{array}{l}\dot{0} \\
\dot{8}\end{array}$ & $\dot{0}$ & $\begin{array}{l}\dot{0} \\
\dot{\infty}\end{array}$ & $\stackrel{\dot{0}}{=}$ & $\stackrel{\dot{O}}{n}$ & $\dot{8}$ & & & & & & & & \\
\hline$\vec{\omega}$ & $\frac{0}{a}$ & $\begin{array}{l}\dot{0} \\
\dot{8}\end{array}$ & $\begin{array}{l}\dot{0} \\
\dot{0}\end{array}$ & $\begin{array}{l}\dot{D} \\
\dot{U} \\
\text { d }\end{array}$ & $\stackrel{b}{\infty}$ & ? & $\dot{0}$ & $\frac{0}{a}$ & $\begin{array}{l}\dot{0} \\
\dot{\omega}\end{array}$ & $\begin{array}{l}\dot{0} \\
\dot{8}\end{array}$ & $\stackrel{\dot{0}}{=}$ & $\stackrel{\circ}{\circ}$ & $\frac{\dot{0}}{\dot{u}}$ & $\dot{8}$ & & & & & & & \\
\hline $\bar{\perp}$ & $\begin{array}{l}\dot{0} \\
\dot{\infty}\end{array}$ & $\stackrel{\dot{0}}{\omega}$ & b & $\stackrel{0}{N}$ & $\dot{8}$ & $\stackrel{0}{\infty}$ & $\begin{array}{l}0 \\
\dot{O} \\
\dot{N}\end{array}$ & i & $\stackrel{0}{\circ}$ & $\begin{array}{l}1 \\
\dot{8} \\
8\end{array}$ & $\begin{array}{l}\circ \\
\dot{8}\end{array}$ & $\begin{array}{l}\dot{0} \\
\text { Oे }\end{array}$ & $\begin{array}{l}0 \\
\text { in }\end{array}$ & $\begin{array}{l}1 \\
0 \\
0\end{array}$ & $\overline{8}$ & & & & & & \\
\hline $\bar{u}$ & $\frac{1}{10}$ & $\begin{array}{l}\dot{0} \\
\dot{\infty}\end{array}$ & $\stackrel{\dot{0}}{=}$ & $\frac{0}{a}$ & $\begin{array}{l}0 \\
\dot{0}\end{array}$ & $\stackrel{\circ}{\circ}$ & $\begin{array}{l}0 \\
0 \\
1\end{array}$ & $\begin{array}{l}\dot{0} \\
\dot{8}\end{array}$ & $\begin{array}{l}\dot{0} \\
\text { O }\end{array}$ & $\frac{\dot{0}}{n}$ & $\begin{array}{l}\dot{0} \\
\dot{N}\end{array}$ & $\begin{array}{l}\dot{0} \\
\dot{8}\end{array}$ & !் & $\begin{array}{l}8 \\
8\end{array}$ & $\stackrel{0}{0}$ & $\dot{8}$ & & & & & \\
\hline $\bar{a}$ & $\begin{array}{l}\circ \\
8\end{array}$ & $\stackrel{\circ}{\circ}$ & : & 웅 & $\stackrel{\circ}{=}$ & $\begin{array}{l}\dot{0} \\
\dot{\infty}\end{array}$ & $\begin{array}{l}\dot{0} \\
\dot{\infty} \\
\infty\end{array}$ & $\stackrel{\circ}{\square}$ & $\stackrel{\dot{\omega}}{\omega}$ & $\begin{array}{l}\dot{0} \\
\dot{\infty}\end{array}$ & 요 & $\begin{array}{l}\text { O } \\
\text { ĩ }\end{array}$ & $\stackrel{\circ}{\circ}$ & $\begin{array}{l}0 \\
\varnothing \\
\infty\end{array}$ & $\stackrel{0}{u}$ & $\begin{array}{l}\dot{0} \\
\text { in } \\
\Delta\end{array}$ & $\dot{8}$ & & & & \\
\hline $\bar{\Xi}$ & $\stackrel{0}{\dot{N}}$ & $\stackrel{0}{\stackrel{+}{N}}$ & $\stackrel{0}{6}$ & $\stackrel{\circ}{\infty}$ & i & $\stackrel{0}{\infty}$ & $\begin{array}{l}0 \\
\dot{O} \\
\dot{O}\end{array}$ & $\dot{8}$ & $\begin{array}{l}\dot{0} \\
\dot{8}\end{array}$ & $\stackrel{0}{8}$ & $\begin{array}{l}0 \\
\dot{\infty}\end{array}$ & $\dot{8}$ & $\stackrel{0}{\ominus}$ & $\frac{\dot{0}}{\omega}$ & $\begin{array}{l}\dot{b} \\
\dot{\infty}\end{array}$ & $\begin{array}{l}\dot{0} \\
\dot{8}\end{array}$ & : & $\dot{8}$ & & & \\
\hline$\infty$ & $\stackrel{b}{\omega}$ & $\begin{array}{l}\dot{\omega} \\
\dot{\omega}\end{array}$ & : & $\frac{0}{\square}$ & $\frac{\dot{0}}{N}$ & $\stackrel{\circ}{\omega}$ & ì & : & $\begin{array}{l}\dot{0} \\
0\end{array}$ & $\frac{\dot{0}}{\dot{u}}$ & $\begin{array}{l}\dot{0} \\
8 \\
8\end{array}$ & $\begin{array}{l}\dot{0} \\
\dot{0} \\
\dot{0}\end{array}$ & $\begin{array}{l}\dot{0} \\
\dot{8}\end{array}$ & $\dot{8}$ & $\begin{array}{l}\dot{0} \\
\dot{0} \\
\text { un }\end{array}$ & $\stackrel{0}{\infty}$ & $\begin{array}{l}\dot{0} \\
\text { in } \\
+\end{array}$ & $\begin{array}{l}1 \\
\dot{i} \\
u \\
u\end{array}$ & $\overline{8}$ & & \\
\hline 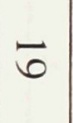 & ஜ & $\begin{array}{l}\dot{0} \\
\text { i } \\
\text { and }\end{array}$ & $\frac{\dot{b}}{0}$ & $\stackrel{0}{\not}$ & $\begin{array}{l}\dot{0} \\
\dot{9}\end{array}$ & $\begin{array}{l}\dot{0} \\
0 \\
8\end{array}$ & $\begin{array}{l}0 \\
\dot{u}\end{array}$ & : & $\begin{array}{l}\dot{0} \\
\dot{8}\end{array}$ & $\begin{array}{l}\dot{0} \\
\dot{\omega}\end{array}$ & $\begin{array}{l}\dot{0} \\
\dot{\infty}\end{array}$ & $\stackrel{0}{\omega}$ & 'ं & $\begin{array}{l}\circ \\
\dot{1} \\
\dot{I}\end{array}$ & $\begin{array}{l}0 \\
\dot{O} \\
0\end{array}$ & $\stackrel{0}{\circ}$ & ○ & $\begin{array}{l}\dot{0} \\
\dot{2} \\
\text { in }\end{array}$ & $\underset{\infty}{\stackrel{0}{\omega}}$ & $\dot{8}$ & \\
\hline$\tilde{0}$ & : & $\begin{array}{l}\circ \\
8\end{array}$ & : & $\begin{array}{l}0 \\
\dot{N}\end{array}$ & $\begin{array}{l}0 \\
\dot{0} \\
\dot{0}\end{array}$ & $\begin{array}{l}\dot{0} \\
\dot{\omega}\end{array}$ & $\begin{array}{l}0 \\
0 \\
0\end{array}$ & do & $\stackrel{0}{\dot{\omega}}$ & $\begin{array}{l}0 \\
0 \\
0\end{array}$ & $\stackrel{0}{a}$ & $\frac{0}{N}$ & $\frac{\dot{0}}{\sigma}$ & $\frac{0}{6}$ & : & $\stackrel{0}{9}$ & $\stackrel{0}{0}$ & Oे & $\stackrel{\dot{0}}{\omega}$ & $\begin{array}{l}0 \\
\text { un } \\
u\end{array}$ & $\dot{8}$ \\
\hline
\end{tabular}




\section{APPENDIX G}

\section{Correlate Matrix of Variables in Low-rise Residences}

- Independent Variable: Neighbourhood Satisfaction (N)

- Physical Quality of Housing: 1. Length of Tenure; 2. Construction Time; 3. Unit Size; 4. Type of Ownership;

- Neighbourhood Description: 5. Same Floor Neighbours; 6. Same building Neighbours; 7.

Willingness to know neighbours; 8. Safety and Security; 9. Annoyance and Nuisances; 10.

Participation in Neighbourhood Activities; 11. Neighbourhood Comparison;

- Overall Residential Evaluation: 12. Environmental Satisfaction; 13. Dissatisfied Issues; 14. Residential Area Selection; 15. Elevator Service

- Socio-economic-demographic Data: 16. Gender; 17. Age; 18. Education Level; 19. Household Income; and 20. Family Population.

\begin{tabular}{|c|c|c|c|c|c|c|c|c|c|c|c|c|c|c|c|c|c|c|c|c|c|}
\hline & Z & - & $N$ & $\omega$ & $\Delta$ & ur & $a$ & $\checkmark$ & $\infty$ & 0 & $\bar{\sigma}$ & $=$ & $\bar{N}$ & $\bar{\omega}$ & $\bar{D}$ & $\bar{u}$ & $\bar{a}$ & $\bar{\nu}$ & $\bar{\infty}$ & $\overline{6}$ & $\tilde{O}$ \\
\hline Z & $\overline{8}$ & & & & & & & & & & & & & & & & & & & & \\
\hline- & $\begin{array}{l}\dot{D} \\
\text { N }\end{array}$ & $\overline{8}$ & & & & & & & & & & & & & & & & & & & \\
\hline$N$ & $\begin{array}{l}\text { b } \\
\text { Na }\end{array}$ & $\begin{array}{l}0 \\
9 \\
9\end{array}$ & $\overline{8}$ & & & & & & & & & & & & & & & & & & \\
\hline$\omega$ & $\frac{0}{D}$ & $\begin{array}{l}1 \\
0 \\
0\end{array}$ & $\begin{array}{l}\dot{0} \\
\text { N }\end{array}$ & $\overline{8}$ & & & & & & & & & & & & & & & & & \\
\hline$\triangle$ & $\begin{array}{l}0 \\
\stackrel{\sim}{0}\end{array}$ & 영 & $\stackrel{0}{=}$ & $\begin{array}{l}\dot{0} \\
0 \\
1\end{array}$ & $\overline{8}$ & & & & & & & & & & & & & & & & \\
\hline un & $\begin{array}{l}0 \\
\text { w }\end{array}$ & 요 & $\begin{array}{l}0 \\
\text { Nu }\end{array}$ & $\underset{\omega}{\dot{\omega}}$ & $\begin{array}{l}\dot{0} \\
0 \\
0\end{array}$ & $\overline{8}$ & & & & & & & & & & & & & & & \\
\hline$a$ & $\begin{array}{l}\dot{0} \\
+\end{array}$ & $\frac{0}{\infty}$ & $\frac{0}{N}$ & $\frac{\dot{0}}{\dot{c}}$ & $\begin{array}{l}\dot{0} \\
0\end{array}$ & $\underset{\omega}{\omega}$ & $\overline{8}$ & & & & & & & & & & & & & & \\
\hline$\checkmark$ & $\stackrel{0}{ \pm}$ & $\begin{array}{l}0 \\
0 \\
0\end{array}$ & 요 & O & $\frac{0}{0}$ & $\begin{array}{l}\dot{0} \\
+\end{array}$ & $\underset{\underset{\perp}{\infty}}{\dot{\alpha}}$ & $\overline{8}$ & & & & & & & & & & & & & \\
\hline$\infty$ & ô & $\begin{array}{l}\dot{0} \\
\text { id }\end{array}$ & $\begin{array}{l}\dot{0} \\
\underline{N}\end{array}$ & $\begin{array}{l}0 \\
0 \\
\text { Un }\end{array}$ & $\frac{0}{N}$ & $\begin{array}{l}\dot{0} \\
\text { a }\end{array}$ & $\begin{array}{l}\dot{0} \\
\text { N }\end{array}$ & $\begin{array}{l}0 \\
\dot{a} \\
\text { a }\end{array}$ & $\overline{8}$ & & & & & & & & & & & & \\
\hline
\end{tabular}




\begin{tabular}{|c|c|c|c|c|c|c|c|c|c|c|c|c|c|c|c|c|c|c|c|c|c|}
\hline 6 & $\frac{0}{\omega}$ & $\begin{array}{l}\dot{0} \\
0\end{array}$ & 웅 & 웅 & : & $\stackrel{0}{\sim}$ & $\frac{b}{A}$ & 요 & $\stackrel{\circ}{\alpha}$ & $\overline{8}$ & & & & & & & & & & & \\
\hline $\bar{\sigma}$ & i & ن் & $\frac{O}{\not}$ & $\begin{array}{l}\dot{0} \\
0\end{array}$ & $\stackrel{\circ}{=}$ & $\begin{array}{l}\dot{0} \\
\text { i }\end{array}$ & $\begin{array}{l}\dot{0} \\
\text { ú }\end{array}$ & $\begin{array}{l}0 \\
\text { iv }\end{array}$ & $\frac{0}{\omega}$ & $\frac{1}{a}$ & $\overline{8}$ & & & & & & & & & & \\
\hline$=$ & $\underset{N}{0}$ & $\begin{array}{l}\dot{\omega} \\
\dot{\phi}\end{array}$ & $\frac{0}{6}$ & 'ं & $\stackrel{i}{\underline{N}}$ & $\begin{array}{l}\dot{\omega} \\
\dot{\omega}\end{array}$ & $\begin{array}{l}\dot{0} \\
\text { i }\end{array}$ & $\begin{array}{l}0 \\
\stackrel{1}{0}\end{array}$ & $\underset{\infty}{\stackrel{\infty}{\infty}}$ & $\frac{0}{\omega}$ & $\frac{0}{a}$ & $\overline{8}$ & & & & & & & & & \\
\hline $\bar{N}$ & $\begin{array}{l}0 \\
0 \\
0\end{array}$ & $\frac{\dot{0}}{n}$ & $\underset{\dot{\omega}}{\dot{\omega}}$ & $\frac{0}{1}$ & 움 & $\begin{array}{l}\circ \\
\circ \\
\perp\end{array}$ & $\begin{array}{l}0 \\
\stackrel{\omega}{0}\end{array}$ & $\begin{array}{l}\dot{0} \\
\dot{0}\end{array}$ & $\begin{array}{l}0 \\
\dot{N}\end{array}$ & $\stackrel{0}{0}$ & $\frac{\dot{0}}{\omega}$ & $\begin{array}{l}0 \\
0 \\
0\end{array}$ & $\overline{8}$ & & & & & & & & \\
\hline $\bar{\omega}$ & 응 & $\dot{\vartheta}_{0}$ & 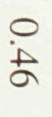 & $\begin{array}{l}0 \\
\text { i } \\
+\end{array}$ & $\begin{array}{l}0 \\
\text { O }\end{array}$ & $\frac{0}{N}$ & : & o & $\begin{array}{l}\dot{0} \\
0\end{array}$ & $\stackrel{\circ}{\circ}$ & $\stackrel{0}{9}$ & @ & $\begin{array}{l}\dot{\omega} \\
\dot{\omega}\end{array}$ & $\overline{8}$ & & & & & & & \\
\hline $\bar{A}$ & $\begin{array}{l}\dot{0} \\
\text { i⿱ }\end{array}$ & $\stackrel{\circ}{8}$ & $\frac{0}{2}$ & $\frac{\dot{0}}{\dot{u}}$ & $\frac{0}{2}$ & 웅 & $\begin{array}{l}0 \\
\infty \\
\infty\end{array}$ & $\frac{0}{6}$ & $\frac{0}{0}$ & @ & $\frac{\dot{0}}{n}$ & $\stackrel{0}{=}$ & $\frac{\dot{0}}{\bar{c}}$ & i & $\overline{8}$ & & & & & & \\
\hline $\bar{n}$ & $\begin{array}{l}\circ \\
\text { a }\end{array}$ & $\stackrel{0}{\square}$ & $\begin{array}{l}\dot{0} \\
\text { in }\end{array}$ & $\frac{0}{2}$ & $\begin{array}{l}\dot{0} \\
\text { O }\end{array}$ & $\begin{array}{l}0 \\
\text { un }\end{array}$ & $\frac{b}{2}$ & $\frac{0}{\infty}$ & $\frac{0}{\omega}$ & $\frac{0}{\infty}$ & $\begin{array}{l}0 \\
\dot{\tilde{o}}\end{array}$ & $\frac{0}{u}$ & $\frac{0}{\square}$ & O & $\begin{array}{l}\dot{0} \\
\text { i }\end{array}$ & $\overline{8}$ & & & & & \\
\hline $\bar{a}$ & 용 & $\begin{array}{l}\dot{0} \\
8\end{array}$ & $\frac{0}{N}$ & $\frac{\dot{0}}{\not}$ & $\frac{0}{\infty}$ & $\frac{0}{\infty}$ & $\begin{array}{l}0 \\
0 \\
0\end{array}$ & $\frac{0}{0}$ & $\begin{array}{l}\text { b } \\
\text { ó }\end{array}$ & $\stackrel{0}{\circ}$ & $\underset{\omega}{\omega}$ & $\frac{0}{N}$ & $\begin{array}{l}1 \\
0 \\
0\end{array}$ & $\dot{8}$ & $\stackrel{0}{\underline{N}}$ & $\begin{array}{l}1 \\
0 \\
0\end{array}$ & $\overline{8}$ & & & & \\
\hline $\bar{v}$ & i & $\frac{0}{\operatorname{ur}}$ & 'ं & OO & $\frac{0}{1}$ & $\begin{array}{l}\dot{\infty} \\
\dot{\infty}\end{array}$ & $\begin{array}{l}\dot{0} \\
\infty \\
\infty\end{array}$ & io & $\begin{array}{l}\dot{0} \\
\text { Oे }\end{array}$ & ○) & $\frac{0}{N}$ & ○ & $\frac{b}{1}$ & i & $\stackrel{0}{\circ}$ & $\frac{0}{v}$ & $\begin{array}{l}\stackrel{0}{0} \\
=\end{array}$ & $\overline{8}$ & & & \\
\hline $\bar{\infty}$ & $\begin{array}{l}0 \\
\text { iv }\end{array}$ & 'ं & 용 & $\begin{array}{l}0 \\
\text { i }\end{array}$ & $\frac{\dot{0}}{\infty}$ & i & 영 & $\stackrel{0}{0}$ & $\frac{b}{\omega}$ & $\frac{0}{0}$ & $\begin{array}{l}\dot{0} \\
\infty \\
\infty\end{array}$ & i & $\begin{array}{l}\dot{N} \\
\infty\end{array}$ & $\frac{b}{v}$ & $\begin{array}{l}1 \\
\dot{0} \\
\infty\end{array}$ & $\begin{array}{l}\dot{0} \\
\text { co }\end{array}$ & $\begin{array}{l}\dot{0} \\
\text { N } \\
t\end{array}$ & $\begin{array}{l}\dot{0} \\
\text { a }\end{array}$ & $\overline{8}$ & & \\
\hline$\overline{6}$ & $\frac{1}{N}$ & $\frac{1}{1}$ & ○ & $\frac{0}{\not}$ & $\begin{array}{l}0 \\
\text { un }\end{array}$ & $\stackrel{0}{v}$ & $\stackrel{0}{\circ}$ & $\frac{0}{0}$ & $\frac{0}{2}$ & $\frac{0}{N}$ & $\begin{array}{l}1 \\
8 \\
8\end{array}$ & $\frac{0}{N}$ & $\dot{\infty}$ & $\begin{array}{l}\dot{\omega} \\
\dot{\omega}\end{array}$ & $\frac{0}{0}$ & $\frac{0}{2}$ & $\frac{0}{\omega}$ & b & $\underset{\dot{L}}{\stackrel{0}{\sim}}$ & $\overline{8}$ & \\
\hline$\tilde{\sigma}$ & $\begin{array}{l}\dot{0} \\
\infty \\
\infty\end{array}$ & 0 & $\frac{\dot{0}}{N}$ & $\underset{\infty}{\infty}$ & $\begin{array}{l}0 \\
\dot{\tilde{o}}\end{array}$ & 웅 & $\dot{0}$ & $\frac{0}{6}$ & $\begin{array}{l}\dot{0} \\
\text { i }\end{array}$ & $\begin{array}{l}\circ \\
\circ \\
1\end{array}$ & $\begin{array}{l}\dot{0} \\
\text { N }\end{array}$ & $\frac{\dot{b}}{\omega}$ & o & $\frac{0}{0}$ & $\begin{array}{l}\dot{0} \\
\text { O }\end{array}$ & $\begin{array}{l}1 \\
\text { Oे } \\
\text { N }\end{array}$ & $\frac{1}{6}$ & $\dot{8}$ & $\begin{array}{l}0 \\
\infty\end{array}$ & $\begin{array}{l}0 \\
\text { iv }\end{array}$ & $\overline{8}$ \\
\hline
\end{tabular}

